ATUALIDADES NA SAÚDE E BEM-ESTAR ANIMAL

Victor Hugo Vieira Rodrigues

(Organizador)

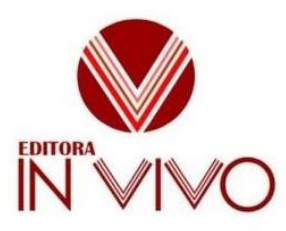

2020 


\section{0 by Editora In Vivo \\ Copyright (C) Editora In Vivo \\ Copyright do Texto (C) 2020 O autor \\ Copyright da Edição (C) 2020 Editora In Vivo}

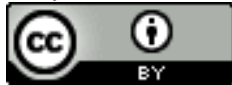

Esta obra está licenciada com uma Licença Creative Commons Atribuição 4.0 Internacional (CC BY 4.0).

O conteúdo desta obra e seus dados em sua forma, correção e confiabilidade são de responsabilidade exclusiva do autor. Permitido o download da obra e o compartilhamento desde que sejam atribuídos créditos ao autor, mas sem a possibilidade de alterá-la de nenhuma forma ou utilizá-la para fins comerciais.

\section{Editor Chefe}

Dr. Everton Nogueira Silva

\section{Conselho Editorial}

\section{Colégio de Ciências da Vida 1.1 Ciências Agrárias}

Dr. Aderson Martins Viana Neto

Dra. Ana Paula Bezerra de Araújo

MSc. Edson Rômulo de Sousa Santos

Dr. Fágner Cavalcante P. dos Santos

MSc. Filomena Nádia

Rodrigues Bezerra

Dra. Lina Raquel Santos Araújo

Dr. Luis de França Camboim Neto

MSc. Maria Emília Bezerra de Araújo

MSc. Yuri Lopes Silva

\subsection{Ciências Biológicas}

Dra. Antonia Moemia Lúcia Rodrigues

Portela

1.3 Ciências da Saúde

Dr. Isaac Neto Goes Silva

Dra. Maria Verônyca Coelho Melo

Dr. Victor Hugo Vieira Rodrigues

\section{Colégio de Humanidades 2.1 Ciências Humanas}

Dra. Alexsandra Maria Sousa Silva

MSc. Francisco Brandão Aguiar

MSc. Julyana Alves Sales

2.2 Ciências Sociais Aplicadas

MSc. Cícero Francisco de Lima

MSc. Erivelton de Souza Nunes

Dra. Maria de Jesus Gomes de Lima

MSc. Maria Rosa Dionísio Almeida

MSc. Marisa Guilherme da Frota

3 Colégio de Ciências Exatas, Tecnológica e Multidisciplinat

\subsection{Ciências Exatas e da Terra}

Dra. Irvila Ricarte de Oliveira Maia

3.2 Engenharias

MSc. Henrique Nogueira Silva

Dados Internacionais de Catalogação na Publicação - CIP

\begin{tabular}{|c|c|}
\hline \multirow[t]{2}{*}{ V657a } & $\begin{array}{l}\text { Rodrigues, Victor Hugo Vieira. } \\
\text { Atualidades na saúde e bem-estar animal [livro eletrônico]. / Organizador: Victor Hugo } \\
\text { Vieira Rodrigues. Fortaleza: Editora In Vivo, } 2020 . \\
\text { 129p. }\end{array}$ \\
\hline & $\begin{array}{l}\text { Bibliografia. } \\
\text { ISBN: } 978-65-991243-2-7 \\
\text { Doi: } 10.47242 / 978-65-991243-2-7\end{array}$ \\
\hline
\end{tabular}

CDD 590.7 


\section{APRESENTAÇÃO}

Este primeiro volume desta obra é dirigido para aqueles que precisam das informações essenciais e atuais sobre a saúde das diversas espécies animais, bem como o seu bem-estar, abrangendo diversas áreas da medicina veterinária, zootecnia. Procuramos fornecer os fatos clínicos mais importantes, sem nos atermos em detalhes acadêmicos que, embora sejam necessários para alguns, só dificultam a compreensão das coisas que realmente importam para a maioria das pessoas que trabalham no cotidiano de sua profissão. Há, certamente, infinitos argumentos sobre o que considerado essencial ou básico, nós oferecemos nesta obra uma apresentação baseada em trabalhos realizados na patologia animal, patologia clínica, clínica médica, anestesiologia, bem-estar, tanto nas espécies domésticas como nas espécies silvestres.

Os diversos trabalhos publicados nesta obra relatam da importância do bem-estar animal, métodos de diagnóstico de risco à saúde na interação entre seres humanos, os animais e o ambiente, manejo animal e relatos de casos de várias doenças que podem auxiliar no emprego de um terapêutica mais específica e eficiente para promover uma melhor qualidade de vida dos animais ou proporcionar um mais conhecimento sobre a prevenção, no controle e no diagnóstico situacional de doenças transmissíveis ao homem pelos animais, as zoonoses. Os animais devem ser livres de desconforto, em um ambiente com abrigo, com temperaturas confortáveis para a espécie e superfícies adequadas para proporcionar conforto. A expressão do comportamento natural da espécie deve ser sempre considerada para medir a qualidade de vida e bem-estar do animal.

Esperamos que este volume seja útil a todos os que estejam à procura de uma literatura concisa sobre a saúde animal e, consequentemente, seu bem-estar como base para estudos médicos veterinários e áreas afins que corroboram com o tema.

V.H.V. Rodrigues 
Capítulo 1 - ATIVIDADE ANTINEOPLÁSICA DA APITOXINA PRODUZIDA POR Apis mellifera NO SEMIÁRIDO, BRASIL

Capítulo 2 - APITOXINA: CARACTERÍSTICAS E POTENCIAIS APLICAÇÕES NA MEDICINA VETERINÁRIA

Capítulo 3 - ASPECTOS CLÍNICOS E LABORATORIAIS NO DIAGNÓSTICO DE CARCINOMA BRONCOALVEOLAR EM CÃO: RELATO DE CASO.

Capítulo 4 - BEM-ESTAR ANIMAL: CONCEITOS E ATUALIZAÇÕES

Capítulo 5 - BEM ESTAR ANIMAL NO TRANSPORTE DE BOVINOS . 50

Capítulo 6 - CICLO ESTRAL EM MARRÃS SUÍNAS DE LINHAGEM HIPERPROLÍFICA

Capítulo 7 - DIROFILARIA IMMITIS EM CÃES: REVISÃO DE LITERATURA

Capítulo 8 - ENFERMIDADES E COMPLICAÇÕES PERINATAIS EM POTROS

Capítulo 9 - ENRIQUECIMENTO AMBIENTAL PARA GRANDES FELINOS EM CATIVEIRO: REVISÃO DE LITERATURA.

Capítulo 10 - ORDEM DE PARIÇÃo E EFICIÊNCIA PLACENTÁRIA EM FÊMEAS SUÍNAS CRIADAS NO SEMIÁRIDO

Capítulo 11 - PESTE SUÍNA AFRICANA: BIOSSEGURIDADE, A MELHOR ESTRATÉGIA 


\title{
ATIVIDADE ANTINEOPLÁSICA DA APITOXINA PRODUZIDA POR Apis mellifera NO SEMIÁRIDO, BRASIL
}

\author{
Victor Hugo Vieira Rodrigues \\ Centro Universitário Uninassau (UNINASSAU), Centro de Saúde, Fortaleza - Ceará \\ http://lattes.cnpq.br/2226604565550002
}

\section{Francisco Humberto Marques Sampaio Júnior}

Universidade Estadual do Ceará (UECE), Faculdade de Veterinária, Fortaleza - Ceará http://lattes.cnpq.br/9353106029410768

\section{Lorena Santos Bezerra}

Universidade de Fortaleza (UNIFOR), Centro de Ciências da Saúde, Fortaleza - Ceará http://lattes.cnpq.br/4384719184797527

\section{José Ryan Ribeiro Tavares}

Centro Universitário Maurício de Nassau (UNINASSAU), Centro de Saúde, Fortaleza - Ceará http://lattes.cnpq.br/8956703680664291

\section{Letícia Soares Holanda}

Centro Universitário Maurício de Nassau (UNINASSAU), Centro de Saúde, Fortaleza - Ceará http://lattes.cnpq.br/1931616014306144

\section{Máyra Carvalho Petelinkar}

Universidade de Fortaleza (UNIFOR), Centro de Saúde, Fortaleza - Ceará http://lattes.cnpq.br/5981111350891482

\section{Lina Raquel Santos Araújo}

Universidade Estadual do Ceará (UECE), Faculdade de Veterinária, Fortaleza - Ceará http://lattes.cnpq.br/7591378438576586

\section{Jael Soares Batista}

Universidade Federal Rural do Semiárido (UFERSA), Centro de Ciências Agrárias, Mossoró - Rio Grande do Norte

http://lattes.cnpq.br/4937343270124186

\section{Informações sobre o \\ artigo: \\ RESUMO}

Recebido em:

15/08/2020

Aceite em:

17/08/2020

Data de publicação:

05/10/2020

Palavras-chave:

Abelha

Apitoxina

Neoplasia
Objetivou-se avaliar a atividade antineoplásica in vitro da apitoxina produzida pela abelha Apis mellifera no semiárido nordestino. Foi avaliada a atividade nas linhagens de células tumorais humanas de adenocarcinoma de próstata (PC3), carcinoma hepatocelular (HEPGE2), melanoma (MAD-MB435) e astrocitoma (SNB19) e usando o método colorimétrico MTT. A apitoxina demonstrou potencial antineoplásico in vitro. Nas concentrações de $50 \mu \mathrm{g} / \mathrm{mL}$ e $25 \mu \mathrm{g} / \mathrm{mL}$ houve efeito citotóxico, com redução da viabilidade nas linhagens PC3, HEPGE2, MAD-MB435 e SNB19, inibindo a viabilidade celular nas linhagens tumorais em relação às células não neoplásicas. A alta atividade antineoplásica fornecem indícios das potencialidades terapêuticas pela apitoxina. 


$\begin{aligned} & \text { ANTINOOPLASTIC ACTIVITY OF APITOXIN } \\ & \text { PRODUCED BY Apis mellifera AT SEMIARID, BRAZIL }\end{aligned}$
ABSTRACT
$\begin{aligned} & \text { The objective was to evaluate the in vitro antineoplastic activity of } \\ & \text { the apitoxin produced by the bee Apis mellifera in the semiarid } \\ & \text { northeast. Activity was evaluated in human tumor cell lineages of } \\ & \text { post-strata adenocarcinoma (PC3), hepatocellular carcinoma } \\ & \text { (HEPGE2), melanoma (MAD-MB435) and astrocytoma (SNB19) } \\ & \text { and using the MTT colorimetric method. The apitoxin showed } \\ & \text { antineoplastic potential in vitro. In the concentrations of } 50 \mu \mathrm{mg} / \mathrm{mL} \\ & \text { and } 25 \mu \mathrm{m} / \mathrm{mL}, \text { there was a cytotoxic effect, with reduced viability } \\ & \text { in the PC3, HEPGE2, MAD-MB435 and SNB19 lines, inhibiting } \\ & \text { cell viability in the tumor lines in relation to non-neoplastic cells. } \\ & \text { The high antineoplastic activity provides evidence of the } \\ & \text { therapeutic potentialities of apitoxin. }\end{aligned}$
Bee
Apitoxin
Neoplasm

\section{INTRODUÇÃO}

Apitoxina é o veneno produzido pela Apis mellifera, por meio de duas glândulas localizadas no interior do abdômen da abelha operária (ORŠOLIĆ, 2012). Esse veneno tem se destacado por apresentar importantes propriedades terapêuticas e suscitado interesse da indústria farmacêutica para extração de novos princípios bioativos a serem utilizados na fabricação de medicamentos (RATCLIFFE et al., 2011). Sua composição consiste de $88 \%$ de água, e os $12 \%$ restantes contém diversos componentes, sendo que mais se destacam são a melitina e a fosfolipase A2, que representam juntas cerca de $75 \%$ do seu peso seco (SCIANI et al., 2010).

O veneno da abelha apresenta diversas atividades terapêuticas, como hemolítica, analgésica, anti-inflamatória, antibacteriana, antifúngica (YANG et al., 2011), antinociceptiva (KIM et al., 2003), hepatoprotetora (PARK et al., 2010) antiviral e antitumoral (YANG et al., 2011). Sua utilização na indústria de cosméticos também tem sido bastante explorada nos últimos tempos, principalmente como auxiliar no retardo do envelhecimento (HAN; LEE; PARK, 2012).

O maior conhecimento da atividade biológica da apitoxina extraída de colmeias no Nordeste brasileiro poderá contribuir para valorização do produto e ampliar o mercado para sua comercialização. Assim, o estudo teve como objetivo avaliar a atividade antineoplásica in vitro da apitoxina produzida pela abelha Apis mellifera no semiárido do Rio Grande do Norte. 


\section{MATERIAL E METODOS}

As amostras da apitoxina da abelha Apis mellifera foram coletadas em município de Maxaranguape no estado do Rio Grande do Norte. A técnica utilizada para coleta foi a mesma proposta por Gramacho, Malaspina e Palma (1992). O veneno foi coletado na forma líquida, sendo submetido à secagem em estufa com circulação forçada de ar a $40^{\circ} \mathrm{C}$, durante 48 horas. Posteriormente o veneno foi raspado do vidro, pesado em balança analítica de precisão e em seguida preparada uma solução de $50 \mathrm{mg} / \mathrm{mL}$ utilizando-se água destilada como diluente. A solução pronta foi então armazenada em recipiente de vidro âmbar, envolvido em papel laminado e acondicionada em freezer $\left(-20^{\circ} \mathrm{C}\right)$ até o momento do uso.

As linhagens tumorais foram provenientes do Banco de células do Rio de Janeiro (BCRJ), e fornecidas pela empresa incubada à Universidade Federal do Ceará (UFC). As células foram cultivadas em frascos plásticos para cultura $(75 \mathrm{~cm} 2$, volume de $250 \mathrm{~mL}) \mathrm{em}$ meio de cultura RPMI-1640, suplementado com $10 \%$ de soro fetal bovino e $1 \%$ de antibiótico (Penicilina/Estreptomicina), sendo posteriormente incubadas em estufa a $37^{\circ} \mathrm{C}$ com atmosfera de 5\% de CO2. O crescimento celular foi observado com a ajuda de um microscópio de inversão a cada 24 horas.

O potencial antineoplásico in vitro da apitoxina foi avaliado por meio do efeito citotóxico da apitoxina em quatro linhagens de células tumorais humanas: adenocarcinoma de próstata (PC3), carcinoma hepatocelular (HEPGE2), melanoma (MAD-MB435), astrocitoma (SNB19) e em linhagem de células sadias não neoplásicas, fibroblastos (L929), que foram utilizadas para comparação e avaliação do efeito seletivo da citotoxicidade da apitoxina entre as células tumorais e normais.

A avaliação da atividade citotóxica foi realizada utilizando o método colorimétrico MTT [brometo de 3-(4,5dimetiltiazol-2-il)-2,5-difeniltetrazolio] por meio da metodologia descrita por MOSMAN (1983). As células foram distribuídas em placas de 96 poços e expostas em diferentes concentrações da solução aquosa de apitoxina: 50; 25; 12,5; 6,25; 3,$125 ; 1,5625$ e $0,78125 \mu \mathrm{g} / \mathrm{mL}$. As placas foram incubadas por $72 \mathrm{~h}$, com $5 \%$ de CO2 e a $37^{\circ} \mathrm{C}$. Posteriormente, foi realizada a adição de $10 \mu \mathrm{L}$ do reagente MTT na concentração de 5 mg.mL-1 em todos os poços da placa, sendo a placa novamente incubada por 4 horas com $5 \%$ de $\mathrm{CO} 2$ à $37^{\circ} \mathrm{C}$.

A viabilidade celular (porcentagem de sobrevivência celular), foi estimada pela seguinte equação: 


$$
\text { \% CS }=\frac{\text { Absorbância das amostras teste }- \text { Absorbância do controle negativo }}{\text { Absorbância controle positivo }- \text { Absorbância do controle negativo }} \times 100
$$

Os resultados estão expressos em percentual de média \pm desvio padrão de viabilidade de células relativo ao controle negativo (considerando 100\% de viabilidade).

\section{RESULTADOS E DISCUSSÃO}

$\mathrm{Na}$ atividade antineoplásica, pode-se verificar que a apitoxina foi citotóxica em todas as linhagens neoplásicas, demonstrando que a capacidade de reduzir a viabilidade foi concentração dependente. Nas concentrações de $50 \mu \mathrm{g} / \mathrm{mL}$ e $25 \mu \mathrm{g} / \mathrm{mL}$ foram observados baixos percentuais de viabilidade celular em todas as linhagens de células neoplásicas testadas. Quando comparado os percentuais de viabilidade nas diferentes concentrações testadas, observou-se que em todas as linhagens testadas houve redução significativa dos percentuais de viabilidade celular nas concentrações de $50 \mu \mathrm{g} / \mathrm{mL}$ e $25 \mu \mathrm{g} / \mathrm{mL}$ em relação aos valores obtidos nas demais contrações. Também, foi possível constatar que na concentração de 12,5 a apitoxina exerceu moderada atividade citotóxica em todas as linhagens testadas. $\mathrm{Na}$ referida concentração, o percentual de viabilidade diferiu significativamente em relação as demais concentrações. Em todas as linhagens celulares testadas, observou-se que a partir da concentração de 6,25 $\mu$ g.mL-1 a apitoxina não apresentou atividade citotóxica, sendo observados altos valores de viabilidade celular e ausência de diferenças significativas dos valores percentuais de viabilidade entres as concentrações de $6.25 \mu \mathrm{g} / \mathrm{mL}, 3.125 \mu \mathrm{g} / \mathrm{mL}$, $1,5625 \mu \mathrm{g} / \mathrm{mL}$ e $0,78125 \mu \mathrm{g} / \mathrm{mL}$.

Ao analisar a atividade citotóxica da apitoxina sobre células normais não neoplásicas, foi possível constatar que nas concentrações de $50 \mu \mathrm{g} / \mathrm{mL}$ e $25 \mathrm{mg} \mathrm{mL}$, apitoxina interferiu pouco na viabilidade das células L929, enquanto que nas referidas concentrações a apitoxina apresentou potencial citotóxico relevante em todas as linhagens de células neoplásicas testadas, sugerindo que a apitoxina exerceu uma ação seletiva, uma vez que nas concentrações de $50 \mu \mathrm{g} / \mathrm{mL}$ e $25 \mu \mathrm{g} / \mathrm{mL}$ a apitoxina foi capaz de inibir a viabilidade celular de forma mais eficiente nas linhas tumorais investigadas.

O presente estudo corrobora com Park et al. (2010), que demonstrou que em doses semelhantes ou mais altas $(1-15 \mu \mathrm{g} / \mathrm{ml})$ o veneno de abelha e melitina inibiram o crescimento de células de câncer de próstata. O principal objetivo dos estudos na quimioterapia é a busca por novos fármacos seletivos que sejam capazes de destruir apenas 
células tumorais, preservando as células normais (ANAZET'TI et al., 2003). Assim, a constatação do efeito seletivo da apitoxina é uma característica extremamente importante para uma possível utilização como agente natural, que possui atividade antineoplásica.

Ao analisar os valores de IC50 encontrados no presente estudo foram encontrados valores que variaram de $3.970 \mu \mathrm{g} / \mu \mathrm{g} / \mathrm{mL}$ a $9.845 \mu \mathrm{g} / \mathrm{mL}$, para as linhagens HEPG2 a MADMB435, respectivamente. Enquanto que para células não neoplásicas L929, o valor de IC50 foi de $9,45 \mu \mathrm{g} / \mathrm{mL}$. A doxorrubicina, utilizada como quimioterápico de referência, também apresentou valores de IC50 que variaram de $0,10 \mu \mathrm{g} / \mathrm{mL}$ a $0,48 \mu \mathrm{g} / \mathrm{mL}$ para as linhagens de PC3 a SNB19, respectivamente. Ao analisar estes resultados, podemos considerar os valores de IC50 como satisfatórios para todas as linhagens neoplásicas testadas.

Os baixos valores de IC50 obtidos podem ser traduzidos como uma maior sensibilidade dessas células à apitoxina. O Instituto Nacional do Câncer dos Estados Unidos (NCI) em seu programa de triagem de drogas anticâncer, considera como compostos ativos com atividade antineoplásica, os compostos que apresentarem IC50 < $30 \mu$ g.mL-1 (ITHARAT et al., 2004). Vale destacar ainda que houve redução significativa entre os valores de IC50 das linhagens SNB19 e MAD-MB435 quando comparado ao valor do IC50 obtido para células da linhagem L929. Esses resultados confirmam que apitoxina apresenta seletividade em relação às linhagens de células normais e células neoplásicas.

Outros estudos também demonstraram resultados satisfatórios quanto ao potencial antitumoral da apitoxina. Lee et al. (2002), demonstraram que in vivo o veneno da abelha inibiu a proliferação de células de melanoma da linhagem B16 e promoveu a morte das células neoplásicas por induzir a apoptose e a fragmentação de DNA, sendo esses fatores considerados pelos referidos autores como os possíveis mecanismos através dos quais o veneno de abelha inibe o crescimento do tumor. Oršolić (2012) sugere que o mecanismo fundamental do efeito citotóxico do veneno da abelha ocorre través da ativação da fosfolipase A2 pela melitina.

\section{CONCLUSÃO}

Baseado em nossos resultados podemos concluir a apitoxina produzida pela abelha Apis mellifera no semiárido do Rio Grande do Norte apresentou um potencial antineoplásico in vitro, uma vez que nas concentrações de $50 \mu \mathrm{g} / \mathrm{mL}$ e $25 \mu \mathrm{g} / \mathrm{mL}$, foram observados efeito citotóxico com redução significativa dos percentuais de viabilidade das linhagens de células 
tumorais humanas de adenocarcinoma de próstata (PC3), carcinoma hepatocelular (HEPGE2), melanoma (MAD-MB435) e astrocitoma (SNB19). Além disso, a apitoxina foi capaz de inibir a viabilidade celular de forma mais eficiente nas linhas tumorais quando comparada a com células normais não neoplásicas, sugerindo uma ação seletiva.

\section{REFERENNCIAS}

ANAZETTI, M. C. et al. Comparative cytotoxicity of dimethylamide-crotonin in the promyelocytic leucemia cell line (HL-60) and human peripheral blood mononuclear cells. Toxicology, v. 188, p. 261-274, 2003.

GRAMACHO, K. P.; MALASPINA, O.; PALMA, M. S. Avaliação da produtividade de veneno em abelhas africanizadas pela utilização da técnica de coleta por estimulação elétrica. Naturalia, v. 1, p. 265, 1992.

HAN, S. M.; LEE, G. G; PARK, K. K. Acute Dermal Toxicity Study of Bee Venom (Apis mellifera L.) in Rats. Toxicological Research, v. 28, n. 2, p. 99-102, 2012.

ITHARAT, A. et al. In vitro cytotoxic activity of thai medicinal plants used traditionally to treat cancer. Journal of Ethnopharmacology, v. 90, n. 1, p. 33-38, 2004.

KIM, H. W. et al. Acupoint stimulation using bee venom attenuates formalin-induced pain behavior and spinal cord fos expression in rats. The Journal of Veterinary Medical Science, v. 65, n. 3, p. 349-355, 2003.

LEE, S. M. et al. Effects of Bee Venom on Glutamate-Induced Toxicity in Neuronal and Glial Cells. Evidence-Based Complementary and Alternative Medicine, v. 2012, p. 1-9, 2012.

MOSMANN, T. Rapid colorimetric assay for cellular growth and survival: application to proliferation and cytotoxicity assays. Journal of Immunological Methods, v. 65, p. 55-63, 1983.

ORŠOLIĆ, N. Bee venom in cancer therapy. Cancer and Metastasis Reviews, v. 31, p. 173-194, 2012.

PARK, M. H. et al. Anti-cancer effect of bee venom in prostate cancer cells through activation of caspase pathway via inactivation of NF-K $\beta$. The Prostate, v. 71, n. 8, p. 801812, 2011.

RATCLIFFE, N. A. et al. Insect natural products and processes: New treatments for human disease. Insect Biochemistry and molecular biology, v. 41, n. 10, p. 747-769, 2011.

SCIANI, J. M. et al. Identification of a novel melittin isoform from Africanized Apis mellifera venom. Peptídes, v. 31, n. 8, p. 1473-1479, 2010. 
YANG, E. J. et al. Melittin restores proteasome function in an animal model of ALS. Journal of Neuroinflammation, v. 8, n. 1, p. 69-78, 2011. 


\section{APITOXINA: CARACTERÍSTICAS E POTENCIAIS APLICAÇÕES NA MEDICINA VETERINÁRIA}

\section{Laís Dantas Ferreira}

Universidade Estadual do Ceará - Faculdade de Veterinária - Fortaleza - Ceará http://lattes.cnpq.br/3128880569387004

\section{Priscila Sales Braga}

Universidade Estadual do Ceará - Faculdade de Veterinária - Fortaleza - Ceará http://lattes.cnpq.br/8056369298308553

\section{Ana Lívia Azevedo Tavares}

Universidade Estadual do Ceará - Faculdade de Veterinária - Fortaleza - Ceará http://lattes.cnpq.br/2300742165284543

\section{Natália Maria Sousa Falcão}

Universidade Estadual do Ceará - Faculdade de Veterinária - Fortaleza - Ceará http://lattes.cnpq.br/4863699081695541

\section{Deborah Cristina Gomes Lucas}

Universidade Estadual do Ceará - Faculdade de Veterinária - Fortaleza - Ceará http://lattes.cnpq.br/3166437472117510

\section{Victor Hugo Vieira Rodrigues}

Centro Universitário Maurício de Nassau - Curso de Medicina Veterinária - Fortaleza - Ceará http://lattes.cnpq.br/2226604565550002

\section{Antonia Moemia Lúcia Rodrigues Portela}

Faculdade Ieducare - FIED - Tianguá - Ceará

http://lattes.cnpq.br/5095487251429690

\section{Maria Gorete Flores Salles}

Universidade da Integração Internacional da Lusofonia Afro-Brasileira - Instituto de Desenvolvimento Rural Redenção - Ceará

http://lattes.cnpq.br/7276641106153452

\section{Aderson Martins Viana Neto}

Universidade Estadual do Ceará - Faculdade de Veterinária - Fortaleza - Ceará http://lattes.cnpq.br/4682104695685941

\begin{tabular}{l|l}
$\begin{array}{l}\text { Informações sobre o } \\
\text { artigo: }\end{array}$ & RESUMO \\
Recebido em: & $\begin{array}{l}\text { O veneno da abelha (apitoxina) é uma substância produzida por } \\
\text { abelhas operárias do gênero Apis, tendo em sua constituição } \\
21 / 09 / 2020 \\
\text { diferentes compostos bioativos e possuindo uma gama de } \\
\text { propriedade biológicas. Desta forma, o objetivo do presente }\end{array}$ \\
$22 / 09 / 2020$ & $\begin{array}{l}\text { estudo é evidenciar os componentes, características e potenciais } \\
\text { aplicações da apitoxina na medicina veterinária. Assim, a apitoxina } \\
\text { apresenta efeitos benéficos relacionados a sua atividade anti- } \\
\text { inflamatória, analgésica, antibiótica, genotóxica, estando } \\
\text { relacionados a seus constituintes, como melitina, apamina, }\end{array}$ \\
$05 / 10 / 2020$ &
\end{tabular}


Palavras-chave:

Apamina

Cães

Frango de corte

Leitão

Melitina histamina, fosfolipase A2, etc. O conhecimento das características do veneno da abelha favorece o desenvolvimento de tecnologias, tornando-se uma proposta diferenciada de produto a ser extraído da apicultura com grande potencial para ser aplicado na produção animal. Portanto, a apitoxina apresenta diversas funções biológicas relacionadas a seus componentes, sendo aplicada em tratamentos alternativos no tratamento de enfermidades como a DDV, herpes viral bovina, ou ainda na suplementação de leitões e frangos de corte a fim de elevar sua imunidade e produtividade.

APITOXIN: FEATURES AND POTENTIAL USE IN VETERINARY MEDICINE

\section{ABSTRACT}

Bee venom (apitoxin) is a substance produced by worker bees of the genus Apis, having different bioactive compounds in its constitution and having a range of biological properties. Thus, the aim of this study is to highlight the components, characteristics and potential applications of apitoxin on veterinary medicine. So, apitoxin has beneficial effects related to its anti-inflammatory, analgesic, antibiotic, genotoxic activity, being related to its constituents, such as melitin, apamine, histamine, phospholipase A2, etc. Knowledge of the characteristics of bee venom favors the development of technologies, making it a differentiated product proposal to be extracted from beekeeping with great potential to be applied in animal medicine and production. Therefore, apitoxin has several biological functions related to its components, being applied in alternative treatments in the treatment of diseases such as DDV, bovine viral herpes, or even in the supplementation of piglets and broilers in order to increase their immunity and productivity.

\section{INTRODUÇÃO}

A criação de abelhas é uma importante atividade econômica, com abrangência social, cultural e ambiental. Das espécies de abelhas, apenas $2 \%$ vivem em sociedade (eussociais) e produzem mel. As abelhas do gênero Apis são as mais exploradas visto sua capacidade de produção de mel, e outros produtos apícolas de interesse econômico (pólen, própolis etc.). Além disso, estas abelhas produzem, para fins defensivos, um veneno conhecido como apitoxina (CAMARGO et al., 2002).

A apitoxina é composta por um complexo de substâncias como água (cerca de 30\%) e vários outros componentes, como aminoácidos, enzimas, proteínas e outros componentes em menor quantidade, que durante a ferroada atuam principalmente no sistema nervoso 
(CORREIA- OLIVEIRA et al., 2012; CRUZ-LANDIM, 2009). Entretanto, mesmo com sua letalidade, onde ataques massivos podem levar a sintomas como obstrução das estruturas renais, que podem ser fatais em determinadas situações, se administrada em doses controladas, a apitoxina é um potente medicamento (CORREIA-OLIVEIRA et al., 2012), podendo apresentar eficiência biológica e desenvolvendo um grande potencial farmacológico (MOREIRA, 2012).

Por esse motivo, há milhares de anos, o veneno das abelhas tem sido utilizado de forma terapêutica, através da medicina tradicional chinesa, bem como na Grécia antiga e Egito, sendo utilizada no tratamento de artrites, doenças auto imunes, dor, infecções, câncer e doenças de pele (RATCLIFFE et al., 2011). Na contemporaneidade, a busca por alternativa aos fármacos sintéticos tem resultado em novas descobertas, como o uso terapêutico da apitoxina, o qual foi descrito com várias ações farmacológicas. Deste modo, a obtenção da apitoxina se apresenta como uma atividade complementar da apicultura, visto que possui grande visibilidade no mercado externo (DAMACENA et al., 2005; MATYSIAK et al., 2011).

O veneno da abelha apresenta diversos benefícios dada suas propriedades antiinflamatórias, analgésicas, antibiótica, hipotensora, neuroprotetora, antimutagênicos, antinociceptivos, radioprotetores, tendo ainda capacidade de estimular a circulação sanguínea e aumentar a permeabilidade capilar (FELICE; PADIN, 2012). Além disso, atua no relaxamento dos músculos podendo reduzir a dor muscular; estimula a produção de cortisona pelas glândulas supra renais, podendo reparar a mielina dos axônios das células nervosas (MUTSAERS et al., 2006). Assim, dentre os principais compostos bioativos, destacam-se a melitina, apamina, histamina, fosfolipase A2, hialuronidase, catecolaminas (inclusive a dopamina) e serotonina (KOKOT et al., 2011; ORŠOLIĆ, 2011; SCIANI et al., 2010).

Portanto, dada a importância biológica e farmacêutica da apitoxina, o objetivo deste estudo é evidenciar suas características biológicas, bem como suas aplicações, potenciais e factuais na medicina veterinária.

\section{APITOXINA}

A composição do veneno da abelha específico varia de acordo com a espécie e estação do ano (MORENO; GIRALT, 2015 ; PASCOAL et al., 2019), e é realizado por 
glândulas especializadas, localizadas no abdome de abelhas operárias (PEREIRA et al., 2016; PASCOAL et al., 2019). Este possui reconhecida atividade biológica, sendo produzido principalmente para autodefesa e para defender a colônia contra uma extensa variedade de predadores (DANTAS et al., 2013). Naturalmente, consiste em um líquido de coloração amarelada, gosto amargo, odor pungente e pH levemente ácido (4,5 e 5,5) (HOSSEN et al., 2017. Após injetado, as substâncias componentes da apitoxina atuam principalmente no sistema nervoso, devido aos estímulos desencadeados nos nervos sensitivos periféricos (fibra C), os quais induzem a liberação do neuropeptídeo substância $\mathrm{P}$, desenvolvendo reações como edema localizado, vasodilatação e aumento do fluxo sanguíneo local, causando uma resposta inflamatória (SOUZA; SILVA; MEDEIROS 2017).

É de conhecimento geral que a apitoxina está associada à toxicidade, como resultado da inoculação de 50 e $140 \mu \mathrm{g}$ de veneno (por ferroada) (MORENO; GIRALT, 2015), via ferroada da abelha operária, devido a presença de compostos como fosfolipase A2, lisofosfolipase, hialuronidase, melitina, e peptídeo degranulador de mastócitos que podem causar efeitos tóxicos, levando ao surgimento de sinais clínicos e sintomas de envenenamento. Todavia, componentes não tóxicos, como a fosfatase e $\alpha$-glicosidade, também estão presentes no veneno da abelha. Ademais, ao longo do tempo, descobertas foram realizadas acerca da atividade farmacológica da apitoxina e de seus componentes, que possuem potencial para tratar diferentes enfermidades. Entretanto, o estabelecimento de uma metodologia eficiente para separação e isolamento destes componentes tem impedido a aplicabilidade dos componentes bioativos da apitoxina frustrando a elaboração de novos produtos terapêuticos (CORREIA-OLIVEIRA et al., 2012).

A apitoxina é constituída principalmente por melitina (50\% em matéria seca do veneno), seguida por fosfolipase A2 (12\%), apamina (3\%), peptídeo MCD (3\%), hialuronidase $(2 \%)$, adolapina $(1 \%)$, cardiopep $(<0,7 \%)$, tertiapina $(0,1 \%)$, histamina, dopamina, noradrenalina, neurotransmissores $(<1 \%$; tabela 1$)$. Embora as quantidades individuais sejam alteradas de acordo com as amostras, a proporção de cada composto padronizado na massa total é similar (melitina: 86\%; fosfolipase A2: 13\%; apamina: 2\%). Vale ressaltar que abelhas jovens produzem apitoxina com maior quantidade de melitina. É bem sabido que a síntese e a composição do veneno de abelha é dependente da idade, com uma menor quantidade de melitina encontrada em abelhas mais novas. (Donget al., 2015/Pascoal et al., 2019).

Estes constituintes possuem as mais diversas funções: atividade anti-inflamatória (LEE et al., 2010), anti-nociceptiva (MERLO et al., 2011), anti-aterogênica (KIM et al., 2011), 
cicatrizante (HAN et al., 2011), hepatoprotetora (PARK et al., 2010) e neuroprotetora (KALVAREZ-FISCHER et al., 2013), evidenciando assim a riqueza biológica deste produto natural. Desse modo, estudos envolvendo a aplicabilidade do veneno das abelhas têm buscado avaliar sua efetividade na terapia de diversas enfermidades.

Os efeitos anticancerígenos do veneno de abelha têm sido relatados por diversos autores (KIM et al., 2015; ZHANG et al., 2016), assim como o de componentes individuais, como a fosfolipase A2 (FERGUSON; DUNCAN, 2009) e a melitina (ZHANG et al., 2016). Essas propriedades estão relacionadas com a indução da apoptose e da necrose celular, e efeitos na proliferação, citotoxicidade, e inibição do crescimento de diferentes tipos de células cancerosas (LIU et al., 2014), dentre elas aquelas originadas no cólon (FERGUSON; DUNCAN, 2009/ 2019) e no fígado (ZHANG et al., 2016).

\subsection{Melitina}

Melitina ou alérgeno Api m4 (HOSSEN et al., 2017/), é o composto principal do veneno de abelha, consistindo entre 40 a $60 \%$ da matéria seca da apitoxina. Relata-se que esse composto, juntamente com a apamina, são encontrados apenas no veneno de abelhas do gênero Apis (MORENO; GIRALT, 2015). Esse composto tem sido descrito como um agente anti-inflamatório bastante potente, sendo bem mais potente que o hidrocortisol em modelos animais. A atividade anti-inflamatória deste composto tem sido explorada em diversos casos, incluindo na acne comum, neuro inflamação, arteriosclerose, artrite e inflamação hepática (PASCOAL et al., 2019).

A sua habilidade de romper a membrana lipídica das células, e suas propriedades antimicrobianas são de grande interesse, especialmente para o tratamento de infecções resistentes a drogas. A melitina inibe significativamente a replicação de vírus tanto envelopados (moléculas de melitina se fundem com o envelope viral, formando complexos de ataque semelhantes a poros) como não envelopados, diminuindo a infectividade dos mesmos (PASCOAL et al., 2019).

Segundo Jin et al. (2018), a melitina pode induzir a apoptose e deter o crescimento de células cancerosas como resultado de uma regulação crítica da sinalização dos caminhos relacionados ao câncer. Dessa forma, a melitina pode ter um efeito anticancerígeno como resultado da indução da morte celular por apoptose (tanto dependentes de caspases, como não dependentes). De fato, potencial inibitório de crescimento, e a capacidade de suprimir a metástase de tumores tem sido observado em diversos tipos de células cancerosas como nas 
do fígado, dos rins, da próstata, mama, pulmão, bexiga, estômago e leucêmicas, sugerindo um possível uso em quimioterapia (LIU et al., 2016; MORENO; GIRALT, 2015; PASCOAL et al., 2019). A melitina também tem mostrado induzir mudanças plásticas em caminhos sinalizadores de dor através da sensibilização e ativação de células nociceptoras (PASCOAL et al., 2019).

Apesar as propriedades promissoras que atraem bastante interesse nos campos da farmacologia e da biotecnologia, a melitina pode causar alterações morfológicas e ter efeitos citolíticos e antiproliferativos dose-dependentes, sendo um peptídeo citolítico não-seletivo que pode induzir a lise de células vermelhas sanguíneas ao desestabilizar a membrana celular dessas células (GAJSKI et al., 2016; ABD EL-WAHED et al., 2018; PASCOAL et al., 2019). De fato, quando em pequenas doses, a melitina possui efeitos anti-inflamatórios, aumentando a permeabilidade capilar; em doses altas pode causar prurido, inflamação, irritação e dor no local (LEE; BAE, 2016; PASCOAL et al., 2019). O mecanismo tóxico é baseado na ruptura de bicamadas fosfolipídicas, as quais leva à lise de mastócitos, e a liberação de componentes como enzimas lisossômicas, histamina e serotonina, causando dor e inflamação. A melitina, juntamente com a fosfolipase A2 e hialuronidase, são responsáveis pelas propriedades alérgicas do veneno, rompendo as membranas celulares e aumentando o seu efeito citotóxico (PASCOAL et al., 2019). Tentativas têm sido feitas para evitar esses efeitos colaterais através da fosforilação da melitina em resíduos de aminoácidos específicos; o peptídeo fosforilado possui respostas alérgicas menores quando comparada à melitina in natura. Além disso, estudos estão realizando a incorporação de nanopartículas no composto in natura com o objetivo de reduzir a sua atividade lítica não-específica (ABD EL-WAHED et al., 2018).

\subsection{Apamina}

A apamina é uma neurotoxina com 18 resíduos de aminoácidos que compreende de 2-3\% do peso seco do veneno de abelha (MORENO; GIRALT, 2015; SANTOS-PINTO et al., 2018). Ela é permeável à barreira hematoencefálica, afetando o sistema nervoso central (SNC), e causando hiperatividade e convulsão (SON et al., 2007). É um composto bloqueador específico e de alta afinidade de canais de cálcio-potássio $(\mathrm{Ca} / \mathrm{K})$ de baixa condutividade. Perifericamente, a apamina afeta, de forma seletiva e potente, a permeabilidade ao potássio de membranas de células musculares, e, quando em altas doses, pode causar espasmos musculares e falha respiratória. Esta característica tem sido bastante explorada, tendo sido 
utilizada para identificar a atividade dos canais de $\mathrm{Ca} / \mathrm{K}$ em diferentes células como as do músculo liso visceral, células da micróglia, do córtex da adrenal, hepatócitos e células ventriculares (tecido cardíaco). Esses dois tipos de canais são frequentemente co-expressados em diferentes tecidos, dentre os quais, células do sistema imune (células T, macrófagos e células dendríticas) (VOOS et al., 2017; PASCOAL et al., 2019).

Diversos pesquisadores estudaram aplicações relacionadas ao uso da apamina como anti-inflamatório, antibacteriano, antiviral, antifúngico, antifibrótico (SHIN et al., 2017), antinociceptivo e citotóxico contra células cancerígenas (SON et al., 2007(Pascoal et al., 2019). Assim, em camundongos com doença hepática colestática, esta substância suprimiu a deposição de colágeno e a expressão de genes fibrogênicos, sugerindo seu papel como um potencial alvo terapêutico (PASCOAL et al., 2019).

\subsection{Fosfolipase A2}

Fosfolipase A2 tem sido destacada por ser a enzima mais abundante do veneno de abelha, correspondendo de 10-12\% de seu peso seco (DOS SANTOS-PINTO et al., 2018) . Devido ao seu alto peso molecular e alta antigenicidade, essa enzima tem sido apontada como a principal causa das reações alérgicas sistêmicas ao veneno de abelha (HOSSEN et al., 2016).

Estudos revelaram a potencialidade da fosfolipase A2 no tratamento de distúrbios humanos incluindo a doença de Parkinson, asma, diversos tipos de câncer, como também distúrbios imunomediados como nefrotoxicidade induzida por cisplatina, hepatotoxicidade e nefrite lúpica (PASCOAL et al., 2019). Seu papel nas infecções bacterianas e parasitárias também é descrito. Foi observado que a fosfolipase A2 inibiu o crescimento de algumas enterobactérias gram-negativas (Escherichia coli, Enterobacter cloacae e Citrobacter freundii) e do protozoário patogênico Trypanosoma brucei brucei. Também se confirmou a sua atividade antibactericida contra Escherichia coli, Enterobacter cloacae e Citrobacter freundii (BOUTRIN et al., 2008).

\subsection{Outros componentes}

Os demais componentes de relevância médica estão listados na tabela abaixo, contendo sua porcentagem de peso da matéria seca total de apitoxina e sua conhecida atividade biológica (tabela 1$)$. 
Tabela 1. Componentes da apitoxina com baixas concentrações, de acordo com Pascoal et al. (2019).

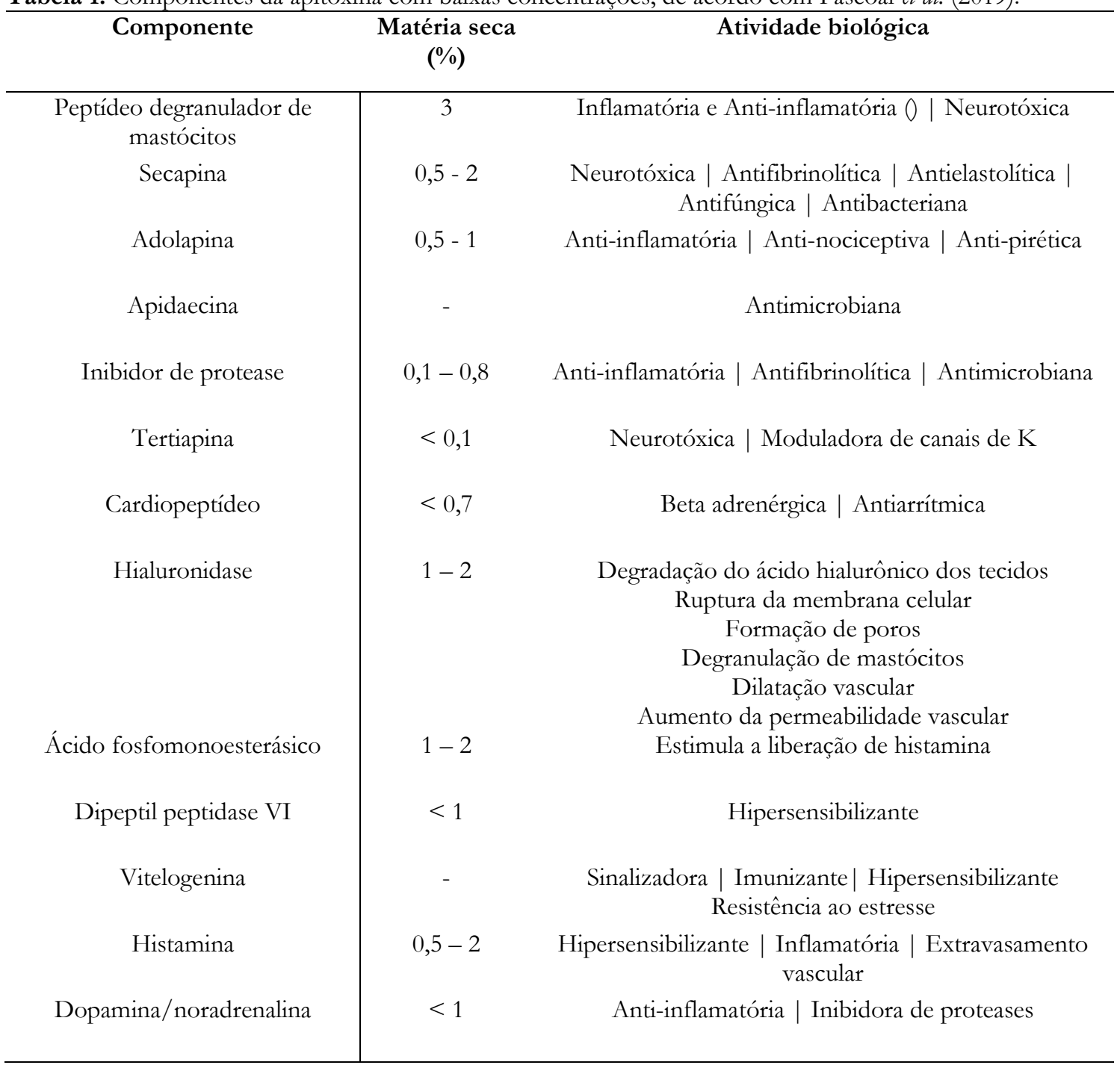

\section{APLICAÇÕES DA APITOXINA NA MEDICINA VETERINÁRIA}

Segundo Stahlke (2013), o estudo do tratamento com apitoxina é denominado de toxinologia e refere-se a um ramo da toxicologia que estuda as propriedades dos venenos animais, tanto para o tratamento de envenenamentos, como para a aplicação terapêutica de seus componentes moleculares. Esta medicina não convencional pode auxiliar no tratamento e na cura de diversas doenças, que podem estar relacionadas com os sistemas respiratório, nervoso, epitelial, entre outros. O veneno das abelhas possui quatro ações principais: antiinflamatória, analgésica, vasomotor e imunoativação (MOREIRA, 2012). Em relação aos componentes identificados nesta substância, estudos mostram que alguns possuem uma potencialidade 100 vezes maior do que certos analgésicos, além de possuírem as outras propriedades faladas anteriormente. Também está relacionada à apitoxina a indução de 
apoptose, necrose e efeitos na inibição da proliferação, citotoxicidade e crescimento celular. A ação que o veneno irá produzir irá depender das frações utilizadas e das quantidades das enzimas presentes na toxina (STAHLKE, 2013).

Os peptídeos são agentes farmacologicamente ativos que podem apresentar propriedades antimicrobianas, sendo aqueles que possuem esta característica, essenciais no combate a diferentes microrganismos (FOSGERAU; HOFFMANN 2015). Devido ao potencial de certos peptídeos de inibir a replicação viral, destruir o envelope viral e de impedir a penetração destes nas células (SKALICKOVA et al. 2015), podendo combater doenças virais, estes têm sido estudados com o objetivo de conhecer seus efeitos práticos na medicina veterinária. Um estudo realizado por Picoli et. al (2018) avaliou in vitro as capacidades antiviral e virucida destes componentes contra o herpesvírus bovino tipo 1 e o vírus da diarreia viral bovina. Neste experimento, atestou-se o potencial efeito antiviral da melitina sobre as duas viroses, além de uma elevada citotoxicidade em células Madin-Darby Bovine Kidney (MDBK), as quais podem ser utilizadas para diagnóstico sorológico de doenças virais em bovinos. Além disso, a apamina demonstrou seu potencial virucida apenas quando esteve associada à melitina. Dessa forma, os resultados desse experimento revelaram o potencial desses peptídeos bioativos no tratamento das diferentes viroses que afetam os bovinos.

A aplicabilidade se estende também de forma a complementar práticas terapêuticas associadas a Medicina Tradicional Chinesa (MTC), como a apipuntura, que se dá pela aplicação de microdoses da toxina em pontos de acupuntura. Assim, seu objetivo é potencializar o efeito da acupuntura e do próprio veneno da abelha, podendo ser injetado diretamente via ferrão da abelha ou solução diluída de veneno. Yasui (2012) direcionando a apipuntura para o tratamento da dor em cães da raça Beagle, relatou que doses de $0,3 \mathrm{mg} / \mathrm{Kg}$ e $0,04 \mathrm{mg} / \mathrm{Kg}$ não produzem alterações comportamentais ou autonômicas significativas além de não produzir nefrotoxidade ou alterações no perfil hematológico, tendo potencial aplicabilidade para animais de companhia.

Ao aplicar apiterapia em cães portadores de doença do disco intervertebral (DDIV), enfermidade resultante da degeneração do disco intervertebral que pode ser evidenciada pelos sinais clínicos que variam de fraqueza muscular a tetraplegia, Tsai et al. (2015) observaram que as injeções de veneno de abelha nos pontos de acupuntura atuaram positivamente no tratamento da disfunção neurológica causada por DDIV. Além disso, a inoculação desta substância exerceu um efeito particularmente forte naqueles cães com DDIV moderada a grave e reduziu drasticamente o tempo de reabilitação clínica, de modo 
que a apiterapia associada ao tratamento de rotina potencializa reduz a disfunção neurológica e a dor induzidas por DDIV.

A apitoxina tem a capacidade de estimular o sistema imunológico de leitões, dada sua aplicação até ao $30^{\circ}$ dia, via parental e apipuntura nos pontos de acupuntura GV-1 (Jiaochao) e GV-20 (Bai-hui). Leitões que receberam a apitoxina apresentaram maior peso corporal, capacidade de sobrevivência e níveis de IgG. Esses relatos indicam que o veneno da abelha apresenta potencial para estimular a imuno-competência na produção suína, fato este correlacionado aos componentes bioativos melitina, fosfolipase A2 e apamina (Han et al., 2009).

$\mathrm{Na}$ produção de frangos de corte, o uso da apitoxina foi relatado em uma pesquisa na qual esta foi utilizada de forma purificada a níveis de inclusão de até $500 \mu \mathrm{g} / \mathrm{kg}$, como uma alternativa ao uso de antibióticos na produção desses animais. Os resultados in vivo apresentaram bastantes resultados positivos, de forma a atestar a eficácia de se incorporar este composto na dieta destes animais, visando seu crescimento e saúde. Dentre os resultados da pesquisa, observou-se que o ganho de peso corporal foi quadraticamente aumentado e a produção relativa de carne de peito até o $21^{\circ}$ dia foi maior, assim como a conversão alimentar desses animais, que teve sua taxa quadraticamente melhorada. Ainda, quando induzida em altos níveis, a apitoxina reduziu o peso relativo do baço, da bolsa de Fabricius, do fígado, e aumentou a concentração da proteína secretora de imunoglobulina A (sIgA) na mucosa ileal e reduziu o conteúdo de óxido nítrico nas amostras de soro. Contudo, o veneno da abelha não afetou o peso da gordura abdominal, assim como não produziu efeitos no ganho de peso corporal, na conversão alimentar e na mortalidade desses animais (KIM et al., 2018).

\section{CONSIDERAÇÕES FINAIS}

Portanto, a apitoxina apresenta diversas funções biológicas relacionadas a seus componentes, principalmente aquelas associadas à melitina, que representa até $60 \%$ da matéria seca da apitoxina, tendo efeitos anti-inflamatórios, anti-viral, dentre outros. Assim, tratamentos alternativos com base nas propriedades clínicas das apitoxina vêm sendo cada vez mais explorados na Medicina Veterinária, como fármaco no tratamento de enfermidades como a DDIV em cães, herpes viral bovina, bem como suplemento para favorecer a imunidade e produtividade de leitões e frangos de corte. 
Ademais, o uso da apitoxina proporciona tratamentos eficazes em diferentes patologias, apresentando pouco ou nenhum efeito colateral, aumentando, consequentemente, a qualidade de vida dos pacientes. Assim, a apitoxina se mostra um potente medicamento no tratamento de diversas enfermidades, com vasto potencial farmacológico e com eficiência biológica comprovada, o que faz deste um importante produto apícola com largo potencial de aplicabilidade.

\section{REFERÊNCIAS}

ABD EL-WAHED, A. A. et al. Bee Venom Composition: from chemistry to biological activity. Studies In Natural Products Chemistry, p. 459-484, 2019.

BOUTRIN, M. C. F.; FOSTER, H. A.; PENTREATH, V. W. The effects of bee (Apis mellifera) venom phospholipase A2 on Trypanosoma brucei brucei and enterobacteria. Experimental Parasitology, v. 119, n. 2, p. 246-251, 2008.

CAMARGO, R. C. R.; PEREIRA, F. M.; LOPES, M. T. R. Produção de mel. Teresina, Piauí, Brasil: EMBRAPA, 2002.

CARDOSO, J. L. C. et al. Animais peçonhentos no brasil: biologia clinica e terapêutica dos acidentes. Sarvier/Fapesp, São Paulo, 2003. 550 p.

CRUZ-LANDIM, C.; ABDALLA, F. C. Glândulas exócrinas das abelhas. Funpec Editora, Ribeirão Preto. 2002. 182 p.

DANTAS, C. G. et al. Apitoxina: Coleta, composição química, propriedades biológicas e atividades terapêuticas. Revista Ibero-Americana de Ciências Ambientais, v.4, n.2, 2013.

FOSGERAU, K.; HOFFMANN, T. Peptide therapeutics: current status and future directions. Drug Discovery Today, v. 20, n. 1, p. 122-128. 2015.

GAJSKI, G. et al. Antitumour action on human glioblastoma A1235 cells through cooperation of bee venom and cisplatin. Cytotechnology, v. 68, n. 4, p. 1197-1205, 2015.

HOSSEN, S.; GAN, S. H.; KHALIL, I. Melittin, a potential natural toxin of crude bee venom: probable future arsenal in the treatment of diabetes mellitus. Journal Of Chemistry, v. 2017, p. 1-7, 2017.

KIM, D. H. et al. Evaluation of bee venom as a novel feed additive in fast-growing broilers. British Poultry Science, v. 59, n. 4, p. 435-442, 2018.

KIM, Y. W. et al. Honeybee venom possesses anticancer and antiviral effects by differential inhibition of HPV E6 and E7 expression on cervical cancer cell line. Oncology Reports, v. 33, n. 4, p. 1675-1682, 2015. 
LEE, G.; BAE, H. Anti-inflammatory applications of melittin, a major component of bee venom: detailed mechanism of action and adverse effects. Molecules, v. 21, n. 5, p. 616, 2016.

LIU, C. C. et al. Biotoxins for cancer therapy. Asian Pacific Journal of Cancer Prevention, v. 15, n. 12, p. 4753-4758, 2014.

MORENO, M.; GIRALT, E. Three valuable peptides from bee and wasp venoms for therapeutic and biotechnological use: melittin, apamin and mastoparan. Toxins, v. 7, n. 4, p. 1126-1150, 2015.

PASCOAL, A. et al.. An overview of the bioactive compounds, therapeutic properties and toxic effects of apitoxin. Food and Chemical Toxicology, v. 134, p. 110864, 2019.

PEREIRA, F. M. et al. Criação de abelhas (Apicultura). 2. ed. rev. e atual. Brasília, DF: Embrapa, 2016. (ABC da Agricultura Familiar, 41). Disponível em: http://www.infoteca.cnptia.embrapa.br/infoteca/handle/doc/1069586

PICOLI, T. et al. Potencial antiviral e virucida da melitina e apamina contra herpesvírus bovino tipo 1 e vírus da diarreia viral bovina. Pesquisa Veterinária Brasileira, v. 38, p. 595604, 2018.

SHIN, S. H. et al. The effects of melittin and apamin on airborne fungi-induced chemical mediator and extracellular matrix production from nasal polyp fibroblasts. Toxins, v. 9, n. 11, p. 348, 2017.

SKALICKOVA, S. et al. Perspective of use of antiviral peptides against influenza virus. Viruses, v. 7, n. 10, p. 5428-5442, 2015.

SON, D. et al. Therapeutic application of anti-arthritis, pain-releasing, and anti-cancer effects of bee venom and its constituent compounds. Pharmacology \& Therapeutics, v. 115, n. 2, p. 246-270, 2007.

SOUZA, R. N.; SILVA, F. K.; MEDEIROS, M. A. Bee venom acupuncture reduces interleukin-6, increases interleukin-10, and induces locomotor recovery in a model of spinal cord compression. Journal of Acupuncture And Meridian Studies, v. 10, n. 3, p. 204-210, 2017.

TSAI, L. C.; LIN, Y. W.; HSIEH, C. L. Effects of bee venom injections at acupoints on neurologic dysfunction induced by thoracolumbar intervertebral disc disorders in canines: a randomized, controlled prospective study. BioMed Research International, v. 2015, 2015:363801

YASUI, A. M. Avaliação da toxicidade e da resposta cutânea local induzidas por doses diluídas de veneno de abelha em cães. 2012. Tese (Mestrado). Universidade Federal Rural do Rio de Janeiro.

ZHANG, Z. et al. Melittin suppresses cathepsin S-induced invasion and angiogenesis via blocking of the VEGF-A/VEGFR-2/MEK1/ERK1/2 pathway in human hepatocellular carcinoma. Oncology Letters, v. 11, n. 1, p. 610-618, 2015. 


\title{
ASPECTOS CLÍNICOS E LABORATORIAIS NO DIAGNÓSTICO DE CARCINOMA BRONCOALVEOLAR EM CÃO: RELATO DE CASO
}

\author{
Máyra Carvalho Petelinkar \\ Universidade de Fortaleza (UNIFOR), Centro de Saúde, Fortaleza - Ceará \\ http://lattes.cnpq.br/5981111350891482 \\ https://orcid.org/0000-0002-7499-4226
}

\section{Letícia Soares Holanda}

Centro Universitário Maurício de Nassau (UNINASSAU), Centro de Saúde, Fortaleza - Ceará http://lattes.cnpq.br/1931616014306144

https://orcid.org/0000-0002-9411-6885

\section{Camila Castelo Trajano}

Universidade de Fortaleza (UNIFOR), Centro de Saúde, Fortaleza - Ceará http://lattes.cnpq.br/2663658854443435

https://orcid.org/0000-0002-1967-7842

\section{José Ryan Ribeiro Tavares}

Centro Universitário Maurício de Nassau (UNINASSAU), Centro de Saúde, Fortaleza - Ceará http://lattes.cnpq.br/8956703680664291

https://orcid.org/0000-0002-4293-4739

\section{Francisco Humberto Marques Sampaio Júnior}

Universidade Estadual do Ceará (UECE), Faculdade de Veterinária, Fortaleza - Ceará http://lattes.cnpq.br/9353106029410768

https://orcid.org/0000-0002-8939-2869

\section{Victor Hugo Vieira Rodrigues}

Centro Universitário Maurício de Nassau (UNINASSAU), Centro de Saúde, Fortaleza - Ceará http://lattes.cnpq.br/2226604565550002

https://orcid.org/0000-0003-2974-8015

Informações sobre o

artigo:

Recebido em

29/07/2020

Aceite em:

$17 / 08 / 2020$

Data de publicação:

$05 / 10 / 2020$

Palavras-chave:

\section{Adenocarcinoma}

Exames laboratoriais

Neoplasia primária

Pulmão

\section{RESUMO}

O adenocarcinoma pulmonar é uma neoplasia que se apresenta como um dos tumores malignos mais comuns em cães, podendo ser diferenciado quanto à malignidade e histologia. Caso o tumor manifeste uma proliferação de células neoplásicas ao longo dos bronquíolos e alvéolos, este é considerado uma neoplasia da categoria carcinoma bronquíolo-alveolar. O êxito no tratamento dessa neoplasia depende da realização de um diagnóstico precoce e preciso. Desta forma, objetivou-se neste trabalho relatar um caso de adenocarcinoma pulmonar e seus métodos de diagnósticos em uma cadela, ressaltando a importância dos exames de rotina. A cadela, da raça Labrador, apresentava tosse, cansaço e arfar constante. Em vista disso, foram realizados exames laboratoriais, como hemograma completo e histopatológico, e de imagem (tomografia e raio-x) que possibilitaram o descarte de doenças mais comuns para se chegar a um diagnóstico conclusivo da neoplasia. 
Com isso, possibilitou o emprego de um tratamento mais adequado, melhorando o prognóstico e, consequentemente, diminuindo a probabilidade de óbito por se tratar de uma doença cancerígena. Concluiu-se, portanto, que o êxito no tratamento do carcinoma depende fundamentalmente do diagnóstico na fase inicial da neoplasia e dos múltiplos exames que possibilitam um melhor prognóstico da doença, obtendo uma melhor eficácia da terapêutica empregada no tratamento animal.

\section{CLINICAL AND LABORATORY ASPECTS DIAGNOSIS OF BRONCHOALVEOLAR CARCINOMA IN A DOG: CASE REPORT}

\begin{tabular}{l} 
ABSTRACT \\
$\begin{array}{l}\text { Pulmonary adenocarcinoma is a neoplasm that presents itself as } \\
\text { one of the most common malignant tumors in dogs, and can be } \\
\text { differentiated in terms of malignancy and histology. If the tumor } \\
\text { manifests as a proliferation of neoplastic cells along the } \\
\text { bronchioles and alveoli, it is considered a neoplasm in the } \\
\text { bronchiololo-alveolar carcinoma category. Success in treating this } \\
\text { neoplasm depends on making an early and accurate diagnosis. The } \\
\text { aim of this study was to report a case of pulmonary } \\
\text { adenocarcinoma and its diagnostic methods in a female dog, } \\
\text { emphasizing the importance of routine exams. The dog, of the } \\
\text { Labrador breed, presented cough, fatigue and constant panting. In } \\
\text { view of this, laboratory tests were performed, such as complete } \\
\text { blood count, histopathology and imaging (tomography and x-ray) } \\
\text { that allowed the dismissal of the most common diseases to obtain } \\
\text { a conclusive diagnosis of neoplasm. This made possible the use of } \\
\text { a more appropriate treatment, improving the prognosis and, } \\
\text { consequently, decreasing the probability of death by a cancerous } \\
\text { disease. It was concluded, therefore, that the success in the } \\
\text { treatment of carcinoma depends fundamentally on the diagnosis in } \\
\text { the initial phase of the neoplasia and on the multiple exams that } \\
\text { allow a better prognosis of the disease, achieving a better efficiency } \\
\text { of the therapy used in animal treatment. }\end{array}$ \\
$\begin{array}{l}\text { Keywords: } \\
\text { Adenocarcinoma } \\
\text { Laboratory tests } \\
\text { Primary neoplasm }\end{array}$ \\
\hline
\end{tabular}

\section{INTRODUÇÃO}

A prevalência de neoplasias em cães vem aumentando consideravelmente e o aumento dessa ocorrência sucede de forma multifatorial. Dentre as causas, pode-se relatar o aumento da longevidade, devido à melhor nutrição com dietas balanceadas; às vacinações, que previne doenças infectocontagiosas; ao uso de métodos de diagnósticos cada vez mais avançados, facilitando na descoberta dessas enfermidades, e, também, dos protocolos 
terapêuticos mais específicos e eficazes que contribuem para uma maior longevidade desses animais (PINHEIRO, 2017).

O câncer pulmonar, quando devidamente diagnosticado, se demonstra comumente de forma de tumores malignos, apresentando uma alta taxa de mortalidade. Dentre essas neoplasias, têm-se os adenocarcinomas, os quais são considerados tumores de categoria pulmonar e podem ser classificados em epiteliais ou mesenquimais, sendo diferenciados quanto à malignidade e histologia (NEGREIROS, 2019). Normalmente, torna-se difícil determinar a topografia precisa de um neoplasma dentro do pulmão, pois isso dependerá de sua origem (LOPEZ, 2018).

Atualmente, a tomografia computadorizada está sendo bastante empregada em animais, possibilitando uma observação mais precisa sobre o tamanho, presença de calcificação, número e densidade da lesão. No entanto, para um diagnóstico definitivo é necessário a realização do exame histopatológico, pois permite determinar se o tumor é benigno ou maligno (PINHEIRO, 2019).

Desta forma, objetivou-se neste trabalho relatar um caso de adenocarcinoma pulmonar, evidenciando seus sinais clínicos e os variados métodos de diagnósticos complementares utilizados em uma cadela idosa da raça Labrador, enfatizando a importância destas análises para que haja êxito no tratamento dessa categoria de neoplasia pulmonar.

\section{METODOLOGIA}

Uma cadela, da raça Labrador, com 12 anos de idade, pesando $35 \mathrm{Kg}$, castrada, foi atendida em uma clínica veterinária, apresentando tosse com presença de muco de coloração transparente e aspecto pastoso. Além disso, foram observados cansaço e um arfar constante.

No exame físico e clínico, observou-se que a paciente apresentava sinais similares de edema pulmonar. Com isso, a cadela foi submetida a uma série de exames, como: hemograma completo, bioquímico com análises dos perfis renal (creatinina e uréia) e hepático (alanina aminotransferase - ALT, fosfatase alcalina) e radiografia do tórax em projeções látero-lateral e ventro-dorsal, na qual confirmou-se a tumefação. Para a realização do hemograma completo utilizou-se o analisador hematológico automático BC-2800 Vet MINDRAY® (Shenzhen, China), e, para uma confirmação do exame e análise morfológica das células, foi realizado a leitura em esfregaço sanguíneo. 
Para o tratamento, foi administrado Lasix ${ }^{\circledR}$ (Furosemida), na concentração de 40 $\mathrm{mg}$, sendo fornecido um comprimido por dia, durante cinco dias, e Mucomucilß, na dosagem de $10 \mathrm{mg} / \mathrm{Kg}$ (N-Acetilcisteína), também por cinco dias, porém duas vezes ao dia.

No mês posterior, ao retornar à clínica veterinária, após o tratamento, a paciente ainda apresentava tosse, cansaço e arfar constantes. Foi solicitado novamente pelo médico veterinário um hemograma completo, bioquímico (análises renal e hepática), radiografia torácica e ultrassonografia abdominal, com o intuito de investigar se havia mais alguma alteração. Porém, no raio-x, destacou-se, novamente, a presença dessa radiopacidade no lobo caudal direito, mas sem a presença de edema pulmonar, e no ultrassom não foi apresentado nenhuma alteração.

Para poder identificar a natureza dessa massa, sugeriu-se um exame de tomografia computadorizada do tórax, realizada no aparelho Tomógrafo GE High, Speed Fxi, para a confirmação de que esta poderia ser uma neoplasia primária. Desse modo, a paciente necessitou passar por uma toracotomia que é o procedimento cirúrgico para retirar todo o lobo caudal direito, para que fosse evitado metástases para outros órgãos. Posteriormente, foi realizado uma biópsia do fragmento da massa neoplásica durante a cirurgia para ser feito um exame histopatológico.

\section{RESULTADOS E DISCUSSÃO}

A faixa etária do animal do presente relato (12 anos de idade), enquadrou-se na descrição da literatura como a de maior probabilidade para a ocorrência de neoplasia pulmonar, como retratado por (PEREIRA et al., 2019). Embora alguns autores relataram que não há predisposição sexual, as fêmeas foram as mais frequentes nos estudos sobre doença oncológica de Barboza et al. (2019), contabilizando aproximadamente 67\% para este sexo. Além disso, de acordo com Leandro et al. (2015), a raça Labrador é uma das mais acometidas com tumor pulmonar primário (PEREIRA et al., 2019).

No exame clínico, foi observado tosse produtiva, intolerância ao exercício, fadiga, dispneia e crepitações na ausculta pulmonar. No exame físico, constatou-se na auscultação sons de crepitações no pulmão, principalmente nas regiões centrais e caudodorsais, evidenciando que o paciente apresentava quadros de edema pulmonar. De acordo com Daleck e De Nardi (2016), os sinais clínicos mais comuns relacionados às neoplasias pulmonares incluem tosse estridente e improdutiva, com evolução crônica e intolerância aos 
exercícios. Este sinal, por sua vez, é proporcional à infiltração pulmonar do tumor que causa interferência na oxigenação, resultando em dispnéia. Após terapia direcionada ao edema, os episódios de tosse continuaram sem secreção mucosa, corroborando com os autores citados.

Nas análises laboratoriais (hemograma completo e bioquímico focando no perfil renal e hepático) não houve alterações significativas. Embora as análises laboratoriais sejam inespecíficas e inconclusivas para o diagnóstico definitivo, as alterações nesses exames poderiam dar um suporte clínico para o prognóstico e tratamento do animal, além de auxiliar no descarte de outras comorbidades (BASTOS, 2020). Porém, se tais análises constatassem alguma alteração poderia ser visualizado um hematócrito elevado, podendo ser explicado pela desidratação que o animal poderia se encontrar, interferindo assim, no valor real da contagem de células vermelhas. Um outro fator que poderia ser encontrado, seria a um quadro de linfopenia e neutrófilos discretamente aumentados, apresentando uma relação com processo infeccioso envolvendo produção de células jovens (PINHEIRO, 2017).

Além disso, em casos de animais com neoplasia pulmonar, os exames bioquímicos poderiam ser identificados com níveis altos, principalmente, de enzimas hepáticas, como o ALT e a fosfatase alcalina (NEGREIROS, 2019), podendo tal elevação estar associada a processo neoplásico (PINHEIRO, 2017).

Considerando que a doença apresenta sinais iniciais inespecíficos (LEANDRO et al., 2015), torna-se essencial para o tratamento um diagnóstico preciso de exames de imagem, como a radiografia, a tomografia e a ultrassonografia, além de análises histopatológicas e imunohistoquímicas. No exame radiográfico, a cadela apresentava opacificação de campos pulmonares em lobos caudais de padrão intersticial levemente infiltrativo e visualização de massa ovalada de radiopacidade de água em lobo caudal direito sugestivo de nódulo pulmonar (Figura 1), tais achados são condizentes com os relatos de Daleck e De Nardi (2016) que relataram achados variados, mas predominantemente nódulos circunscritos solitários ou múltiplos, padrão reticulonodular disseminado intersticial ou padrão alveolar disseminado misto e consolidação lobar. 
Figura 1: Imagem ventro-dorsal do tórax da paciente canina, observa-se imagem circular de radiopacidade de água e limites não definidos em parênquima pulmonar de lobo caudal direito, além de opacificações de campos pulmonares, em lobos cranial direito e caudais, de padrão radiográfico intersticial, sugerindo edema pulmonar.

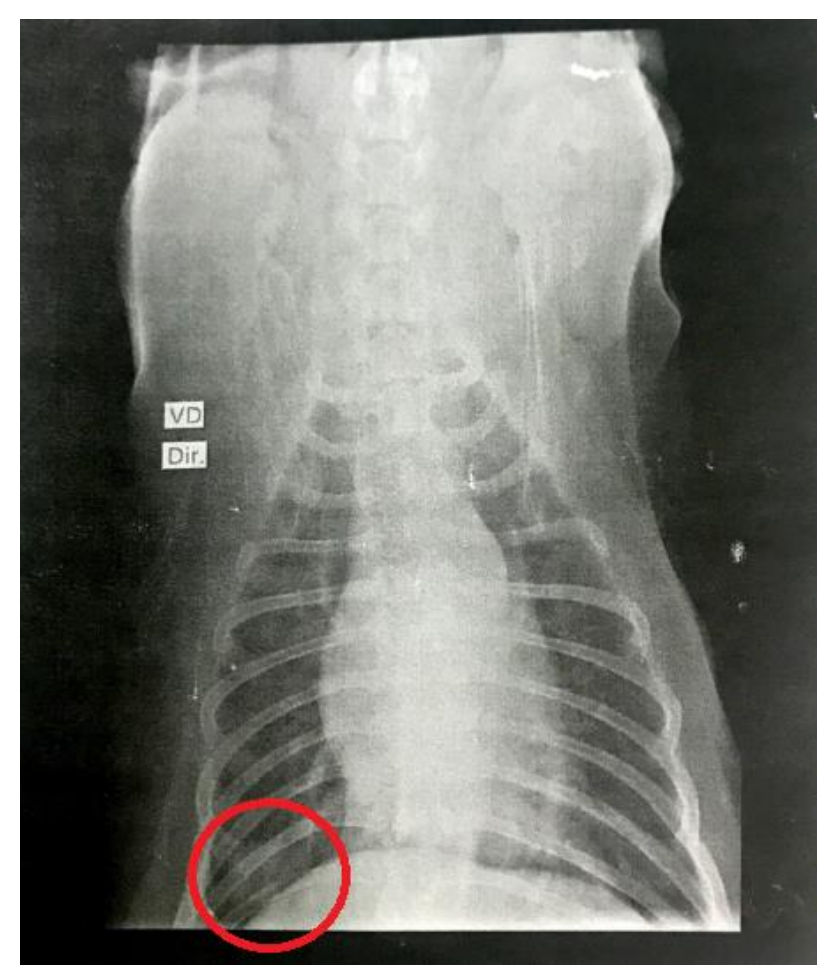

Conforme Daleck e De Nardi (2016) imagens complementares, como a tomografia computadorizada, podem auxiliar no planejamento cirúrgico e na avaliação de processos metastáticos, através da análise de imagens seccionais livres. No caso apresentado, pode-se observar uma massa única de aspecto neoplásico em topografia de lobo caudal direito com dimensões estimadas em 5,6 cm de comprimento, 3,1 cm de altura e 3,1 cm de largura, apresentando margens bem delimitadas, formato ovalado e limites irregulares, aspecto heterogêneo da lesão com região central hipoatenuante e presença de pseudocavitações com conteúdo gasoso, além de diminuta área de mineralização na periferia da massa (Figuras 2). Não foram encontradas lesões nos demais órgãos e o animal não apresentava histórico prévio de neoplasias, características consistentes com processo neoplásico pulmonar primário. 
Figuras 2: Imagem transversa (A), dorsal (B) e sagital (C) da paciente canina, observando-se massa única de aspecto neoplásico em topografia de lobo pulmonar caudal direito.
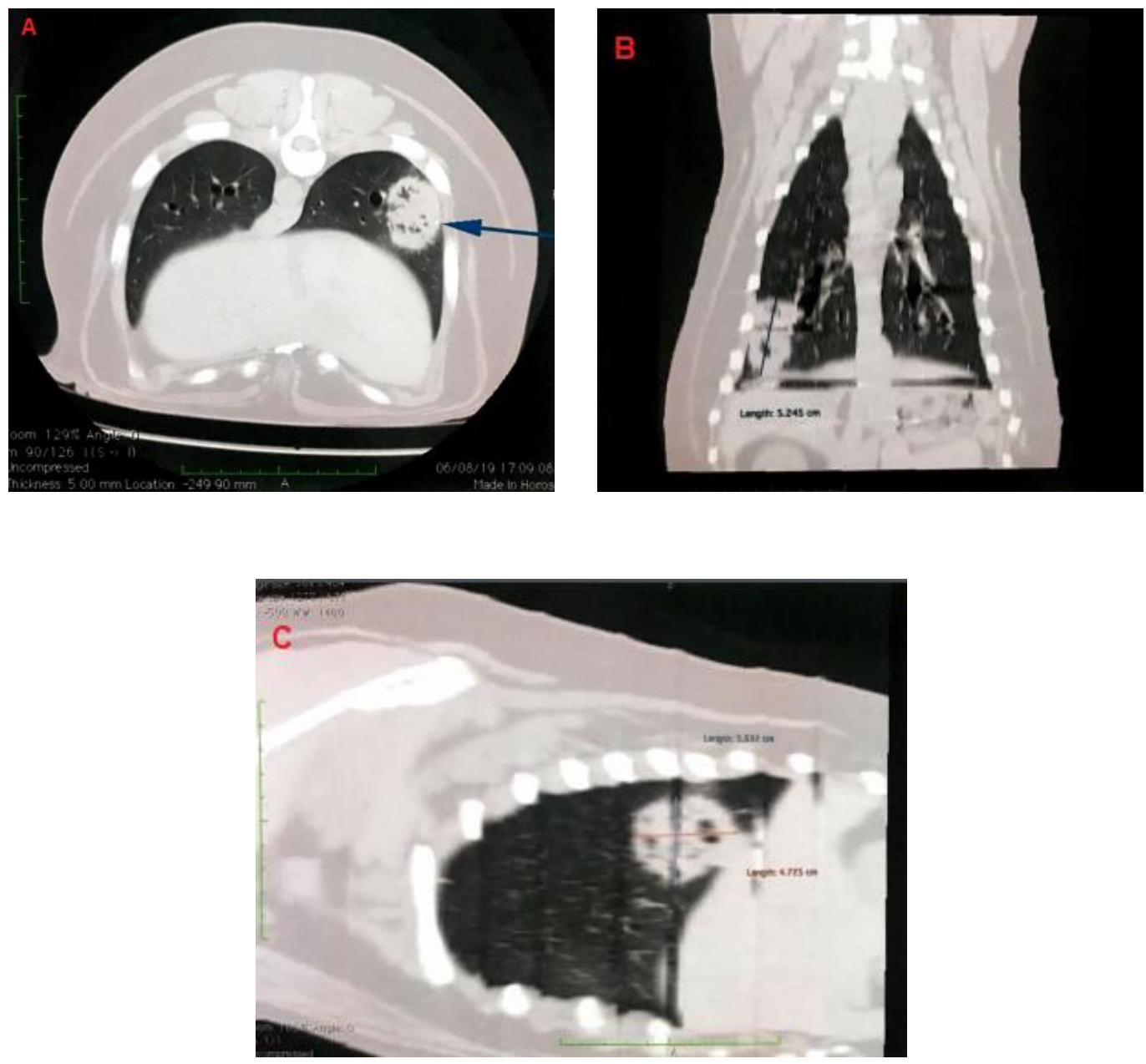

Posteriormente à retirada total do lobo caudal direito, foi realizado uma avaliação histopatológica do carcinoma pulmonar. Macroscopicamente, o exame avaliou lobectomia pulmonar medindo $8,5 \times 7,0$ × 2,5 cm, que apresentou um nódulo elevado medindo $6,0 \mathrm{~cm}$ no eixo maior, confirmando ser um fragmento neoplásico maligno invasivo no parênquima pulmonar, com epitélio característico de carcinoma - células médias e células grandes, cubóides, com núcleos hipercorados, moderado pleomorfismo, citoplasma pálido espumoso e áreas necrosadas.

Adenocarcinomas demonstram heterogeneidade, devida à origem embrionária, às múltiplas funcionalidades e às variações morfológicas dos tipos de células pulmonares (CARVALHO, 2009). Segundo Caprioli et al. (2018), os padrões histológicos encontrados nesses tumores alternam-se entre papilar, acinar, sólido e misto, substituindo o parênquima pulmonar. As células tumorais variam entre cubóides e colunares, de pleomorfismo discreto a moderado e, no interior da massa tumoral, podem ser encontradas áreas de necrose, 
mucina, hemorragia e trombose. Levando em consideração que tumores metastáticos podem apresentar características histológicas semelhantes às neoplasias primárias pulmonares, o que dificulta a determinação da origem das células neoplásicas apenas pelo exame histológico (Oliveira et al., 2019), é necessário o uso de imunohistoquímica para diferenciação e confirmação do diagnóstico definitivo, porém, devido ao alto custo de tratamento e exames, a sua realização pode ser proibitiva.

\section{CONCLUSÃO}

O carcinoma broncoalveolar é uma neoplasia cada vez mais comum e que apresenta altas taxas de mortalidade. A doença, por sua vez, está sendo cada vez mais reconhecida na clínica de pequenos animais, sendo um diagnóstico diferencial para os animais idosos, haja vista que os tutores dos animais relatam que seu pet apresenta tosse crônica. O sucesso do procedimento terapêutico vai depender da análise correta nas fases iniciais. Por fim, a utilização de métodos de imagem, como a tomografia, garantem um diagnóstico correto dessa neoplasia e um melhor prognóstico.

\section{REFERÊNCIAS}

OLIVEIRA, M. C.; COSTA, S. Z. R.; PIRES A. P. C. Adenocarcinoma pulmonar sólido primário em cão. Acta Scientiae Veterinariae. 2019 47: 440p.

RAFAELA A. CAPRIOLI et al. 2018. Achados patológicos e imuno-histoquímicos de neoplasias pulmonares primários em caninos na região metropolitana de Porto Alegre, Rio Grande do Sul. Pesquisa Veterinária Brasileira, Setor de Patologia Veterinária (SPV). 38(6): 1151 - 1158, junho 2018.

CARVALHO, L. 2009. Reclassificação do carcinoma broncopulmonar: Diferenciação do tipo histológico em biópsias por imuno-histoquímica. Rev Port Pneumol 2009; XV (6): 1101-1119, nov/ dez. 2009.

PINHEIRO, G. S. Adenocarcinoma papilífero anaplásico pulmonar em um cão relato de caso. 2017. Trabalho de conclusão de curso (Especialização)-Instituto de Produção e Saúde Animal, Universidade Federal Rural da Amazônia, Belém, 2017.

LUCENA, R. B. et al. Carcinoma bronquíolo-alveolar difuso em um cão: aspectos clínicopatológicos e imuno-histoquímicos. Ciência Rural, Santa Maria, v. 41, n. 1, 2011. 
DE NEGREIROS, A. P. S. Leiomiossarcoma uterino, feocromocitoma em adrenal e adenocarcinoma pulmonar concomitantes em um cão. 2019. Trabalho de conclusão de curso-Centro de Ciências Agrárias, Universidade Federal da Paraíba, Areia, 2019.

BASTOS, P. A. L. M. et al. Micção inapropriada em um gato doméstico: tratamento bem sucedido com fluoxetina. Pubvet, v. 14, n. 5, p. 1-6, mai. 2020.

LÓPEZ, A. Sistema Respiratório, Mediastino e Pleuras. In: Zachary, J. F.; McGavin, M. D. Bases da Patologia Veterinária. $6^{\mathrm{a}}$ Ed. Rio de Janeiro: Elsevier, 2018. p. 461-541.

MANIAM, R. et al. Pulmonary papillary adenocarcinoma with Aspergillus versicolor infection in a dog. Medical Mycology Case Reports, v. 19, p. 25-29, mar. 2018.

DE OLIVEIRA, F. M. Linfoma multicêntrico em cão - relato de caso. 2019. Trabalho de conclusão de curso-Centro de Ciências Rurais, Universidade Federal de Santa Catarina, Curitibanos, 2019.

PEREIRA, L. B. S. B. et al.. Aspectos clínicos, diagnósticos e tratamento do adenocarcinoma pulmonar canino: relato de caso. Medicina Veterinária (UFRPE), Recife, v. 13, n. 4, p. 514-520, 2019. 


\section{BEM-ESTAR ANIMAL: CONCEITOS E ATUALIZAÇÕES}

\section{Michelle Costa e Silva}

Universidade Estadual do Ceará, Faculdade de Medicina Veterinária (FAVET), Fortaleza - Ceará. http://lattes.cnpq.br/2140592626597725

https://orcid.org/0000-0003-3563-3812

\section{Annira Aquino Cortez}

http://lattes.cnpq.br/2260281716882676

\section{Isaac Neto Goes da Silva}

Universidade Estadual do Ceará, Faculdade de Medicina Veterinária (FAVET), Fortaleza - Ceará. http://lattes.cnpq.br/1191488997675957

https://orcid.org/0000-0002-6055-1790

\section{Aline Maia Silva}

Faculdade Terra Nordeste (Fatene), Faculdade de Medicina Veterinária, Caucaia - Ceará.

http://lattes.cnpq.br/1304524070155243

https://orcid.org/0000-0002-0925-0319

\section{Tiago Silva Andrade}

Universidade Estadual do Ceará, Faculdade de Medicina Veterinária (FAVET), Fortaleza - Ceará. http://lattes.cnpq.br/7161796048983496

\section{Jose Nailton Bezerra Evangelista}

Universidade Estadual do Ceará, Faculdade de Medicina Veterinária (FAVET), Fortaleza - Ceará. http://lattes.cnpq.br/3648513271604631

\section{Ricardo Toniolli}

Universidade Estadual do Ceará, Faculdade de Medicina Veterinária (FAVET), Fortaleza, Ceará. http://lattes.cnpq.br/4931712701458453

https://orcid.org/0000-0002-4277-3656

Informações sobre o

artigo:

Recebido em:

$05 / 08 / 2020$

Aceite em:

$17 / 08 / 2020$

Data de publicação:

$05 / 10 / 2020$

Palavras-chave:

Bem estar

Ciência

Espécie

\section{RESUMO}

O bem-estar animal (BEA) tem despertado nos últimos anos a preocupação de criadores, produtores, consumidores e da indústria de produtos de origem animal. Isso porque as condições em que os animais vivem além de causar problemas físicos e psicológicos aos animais individualmente, onde podemos citar os animais de companhia, também podem ocasionar em animais de produção a redução da produtividade, prolificidade e qualidade dos produtos provenientes desses animais. Isso já vem sendo cada vez mais documentado em amostras de leite e principalmente produtos cárneos. Por esta razão que o agronegócio tem investido em medidas que garantam melhor o bem-estar dos animais, onde a alteração na melhoria das condições de vida dos animais advém de estudos científicos sobre o BEA. Assim torna-se importante o conhecimento sobre como o BEA vem sendo estudado e avaliado nas diferentes espécies sob o ponto de vista da ciência e seu 
impacto para a sociedade mundial. Diante disso, este trabalho teve como objetivo realizar uma revisão sobre as definições, critérios de avaliação e atualizações acerca do bem-estar animal que vêm sendo estudados pela ciência.

\section{ANIMAL WELFARE: CONCEPTS AND UPDATES}

ABSTRACT
$\begin{aligned} & \text { Animal welfare (BEA) has aroused the concern of breeders, } \\ & \text { producers, consumers and the animal products industry in recent } \\ & \text { years. This is because the conditions in which animals live in } \\ & \text { addition to causing physical and psychological problems to } \\ & \text { individual animals, where we can cite companion animals, can also } \\ & \text { cause production animals to reduce productivity, prolificacy and } \\ & \text { quality of products from these animals. This has been increasingly } \\ & \text { documented in samples of milk and mainly meat products. For this } \\ & \text { reason, agribusiness has invested in measures that better guarantee } \\ & \text { the welfare of animals, where the change in improving the living } \\ & \text { conditions of animals comes from scientific studies on the BEA. } \\ & \text { Thus, it becomes important to know how BEA has been studied } \\ & \text { and evaluated in different species from the point of view of science } \\ & \text { and its impact on world society. Given this, this work aimed to } \\ & \text { carry out a review of the definitions, evaluation criteria and updates } \\ & \text { on animal welfare that have been studied by science. }\end{aligned}$
Science
Welfare

\section{INTRODUÇÃO}

O bem-estar de um indivíduo é seu estado em relação às suas tentativas de adaptarse ao seu ambiente (BROOM; MOLENTO, 2004). Nos últimos anos os animais de companhia vem estabelecendo uma relação familiar com os seres humanos, muitas vezes sendo utilizados em programas terapêuticos. Nessas relações a preocupação com a qualidade de bem-estar envolve a atenção com a posse responsável e o respeito com a saúde física e mental desses animais (SILVA et al., 2018).

Além disso, em vários países a sociedade civil vem desempenhando um papel crucial no desenvolvimento do conceito de BEA, devido à sua importância também nas relações comerciais. Os produtos oriundos de sistemas de mais alto grau de BEA apresentam valores agregados, de ordem econômica e ética (VERBEKE, 2009).

A introdução de melhorias nas etapas de produção se constitui numa excelente oportunidade para que as indústrias ampliem seus negócios com destaque no mercado de produtos de origem animal, se antecipando às novas demandas e exigências de mercado e 
aliando também a reflexão sobre a ética das ações que preservam o sofrimento animal (PEDRAZZANI et al., 2007).

Os produtores de proteína animal têm sofrido a pressão da sociedade (OLIVEIRA et al., 2008), a qual passou a exigir que as práticas com os animais sejam abordadas cientificamente (DIAS et al., 2015). Essa preocupação pública acaba estimulando mudanças nos sistemas de produção, acarretando na produção de alimentos de origem animal com maior competitividade e sustentabilidade (CORNISH et al., 2016; SMITH et al., 2019).

A preocupação cada vez maior com o BEA por parte de governantes, produtores e consumidores no mundo inteiro se deve muito ao crescente consumo de carne, laticínios, ovos e peixes que estão forçando o mundo a enfrentar os desafios interligados de como sustentar de forma sustentável uma população que se espera 9 bilhões até 2050, controlando também o impacto da produção de alimentos no planeta, nas pessoas e nos animais. Embora tenha melhorado nos últimos anos, há convincente evidência de que a compreensão do público em geral sobre o bem-estar animal ainda é fraca (CORNISH et al., 2016).

Por esta razão tem se tornado cada vez mais necessária a compreensão dos conceitos e principais atualizações sobre os estudos de bem-estar animal.

\section{CONCEITOS DE BEM-ESTAR ANIMAL}

As primeiras tentativas de definir o bem-estar se referiam a indivíduos em harmonia com a natureza, mas a primeira definição utilizável incorporava sentimentos e saúde como parte das tentativas de lidar com o meio ambiente (BROOM, 2011).

As abordagens iniciais para definição do bem-estar animal (BEA) foram baseadas principalmente na exclusão de estados negativos, negligenciando o fato de que durante a evolução os animais otimizaram sua capacidade de interagir e se adaptar ao seu ambiente. (OHL; VAN DER STAAY, 2012).

Independente das definições, mundialmente é aceito como indicador de BEA o princípio das cinco liberdades criado pelo Farm Animal Welfare Council desde 1979 (FAWC, 2010), que determinam para o bem-estar animal: livres de dor, injúrias e doenças, livres de fome e sede, livres de desconforto, livres para expressar o comportamento natural e livres de medo e estresse.

Uma definição simplista de BEA pode ser como o animal se sente agora. Embora experiências afetivas, incluindo emoções, por serem estados subjetivos que não podem ser medidos diretamente em animais, índices fisiológicos e comportamentais indiretos podem 
ser usados com cautela para interpretar tais experiências emocionais (HEMSWORTH et al., 2014).

Os animais desenvolveram sistemas cognitivo-emocionais ("necessidades assistenciais") para lidar com um ambiente variável. Não apresentam apenas as chamadas necessidades fisiológicas, como a necessidade de comida, água e conforto térmico. O valor do bem-estar positivo está relacionado à forma como os animais se inclinam a comportar-se em condições naturais. O valor negativo do bem-estar está relacionado ao estresse, frustração, comportamento anormal, agressividade e redução da capacidade física (BRACKE e HOPSTER, 2006).

Os animais podem ser mantidos como animais de companhia, de trabalho ou para a produção de alimentos, fibra ou para fins científicos ou educacionais. A OIE reconhece que esses propósitos são legítimos e implicam uma responsabilidade ética para garantir que eles sejam tratados corretamente apenas como é definido em padrões internacionais de bemestar da OIE, em reconhecimento dos animais como seres senscientes (OIE, 2017). É possível explorar oportunidades de bem-estar animal orientadas para o produtor, entender o relacionamento entre bem-estar, produtividade, crescimento sustentável e características do produto ou da produção, respeitando ainda o controle climático, enriquecimento ambiental e necessidades específicas de cada espécie e exigências de BEA da sociedade de cada país (AVERÓS et al., 2013).

\section{ANIMAIS DE COMPANHIA}

Os animais de companhia desempenham papéis importantes para as pessoas em todo o mundo, incluindo como companheiros e animais de assistência (WSAVA, 2018). Para muitos veterinários, o bem-estar animal é uma questão de saúde. Enquanto um animal é saudável, também é feliz (LADEWIG, 2008). No entanto, comportamentos indesejáveis são comuns em cães e indicam comprometimento do bem-estar a partir de motivações emocionais subjacentes para o comportamento (por exemplo, ansiedade) ou dos métodos usados pelos proprietários para resolver o problema. Nesse sentido, o adestramento positivo em cães é bastante eficaz no tratamento de distúrbios comportamentais de ansiedade, por promover o bem-estar, uma relação saudável dos animais com seus tutores, com o ambiente que os cercam e a interação com outras pessoas e animais (LINHARES et al., 2018). Em estudo realizado na Inglaterra entre os anos de 2009 e 2014 verificou-se que os cães com menos de três anos de idade estão em um risco proporcionalmente alto de morte devido a 
comportamentos indesejáveis $(33,7 \%)$ em comparação com outras causas específicas de morte (BOYD et al., 2018).

No caso dos felinos domésticos, o manejo na criação e no atendimento médico veterinário desses animais têm apresentado mudanças significativas no sentido de se estabelecer o bem-estar para estes animais, respeitando-se às suas particularidades. Isto porque os felinos domésticos apresentam inúmeras peculiaridades fisiológicas e comportamentais que não podem ser ignoradas quando se procura realizar um bom atendimento a esses animais. Fatores estressantes podem causar impactos na saúde dos felinos, podendo muitas vezes levar alguns animais à eutanásia ou abandono por parte dos tutores, em função da falta de compreensão da complexidade destes (RODAN, 2016).

Nesse sentido, surgiram o Cat-Friendly-Clinic/Cat-Friendly-Practice, criados pela Internacional Society of Feline Medicine (ISFM) e American Association of Feline Practitioners (AAFP), os quais estabelecem um guia de abordagem do paciente felino que qualifica ambientes especializados no atendimento de gatos, a partir de técnicas que compreendem maneiras ideais de transportar o gato até a clínica e na volta para casa, assim como postura do veterinário em relação ao paciente ao longo da consulta (SILVA, 2017). No entanto, para que clínicas, hospitais ou instituições sejam considerados ambientes catfriendly é necessário que estes possuam, no mínimo, um profissional membro da AAFP, além de terem seu cadastro atualizado e aprovado a cada dois anos para manterem a prática. Os estabelecimentos com práticas Cat-Friendly utilizam selos (ouro ou prata) disponibilizados pela ISFM e AAFP (Figura 2) e são listados em websites para que os tutores possam buscar esse tipo de atendimento personalizado (CANNON et al., 2016). No Brasil, atualmente há 26 clínicas certificadas como Cat-Friendly-Practice (AAFP, 2020).

Figura 1. Selos Cat-Friendly-Clinic e Cat-Friendly-Practice disponibilizados pela Internacional Society of Feline Medicine (ISFM) e American Association of Feline Practitioners (AAFP).

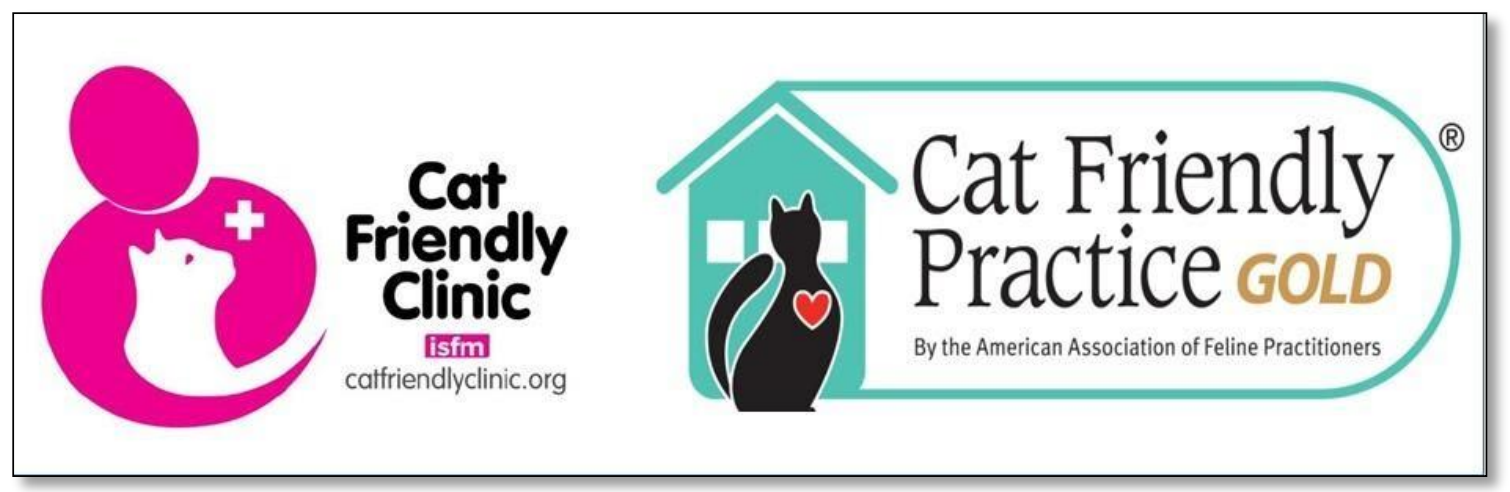

Fonte: SILVA (2017). 
Em cães, o enriquecimento ambiental tem sido uma estratégia comumente utilizada, incluindo o enriquecimento através de interações com humanos e outros animais, classificado como enriquecimento ambiental animado, ou ainda através de brinquedos, estimulação auditiva e olfativa, classificado como enriquecimento ambiental inanimado (Wells, 2004). É importante destacar a importância dessa abordagem uma vez que a expansão das relações homem-animal aumenta as chances de problemas comportamentais dos animais (Chávez e Ubilla, 2014)

\section{ANIMAIS SELVAGENS}

A influência do homem sobre o BEA também tem relevante importância ao se abordar as atividades humanas que privam os animais selvagens de seus requisitos de vida, destruindo ou empobrecendo seu entorno. Infelizmente ainda há falhas em se estabelecer um fundamento ético bem aceito e aplicado para a conservação de animais silvestres. A destruição do habitat priva os requisitos da espécie de vida, causando traumas, sofrimento prolongado e, por fim, a morte (PAQUET; DARIMONT, 2010). O uso de interações sociais positivas e do enriquecimento ambiental, uma ferramenta que possibilita aos animais oportunidades de escolha atrvés do aumento da complexidade ambiental, elevando a expressão de comportamentos naturais, tem sido implementadas para garantir o melhor bem-estar desses animais (AZEVEDO; BARÇANTE, 2018; WILLIAMS et al., 2018).

\section{ANIMAIS DE PRODUÇÃO}

Embora o BEA seja referido como a qualidade de vida de um animal individualmente, em animais de fazenda a avaliação das condições de vida destes deve ocorrer também ao nível da população.

Em 2012, a Organização Mundial de Saúde Animal adotou os 10 "Princípios Gerais para o Bem-Estar dos Animais nos Sistemas de Produção Pecuária", visando orientar o desenvolvimento de padrões de bem-estar animal. Os Princípios Gerais baseiam-se em meio século de pesquisa científica relevante para o bem-estar animal no que diz respeito: (1) seleção genética do comportamento e o temperamento dos animais; (2) influência do ambiente no comportamento e no desenvolvimento de patologias; (3) gestão de grupos para minimizar 
conflitos e permitir contato social positivo entre os animais; (4) efeitos da qualidade ambiental; (5) conforto dos animais; (6) acesso a rações e água de forma adequada; (7) prevenção e controle de doenças, com eutanásia humanitária se necessário; (8) prevenção e tratamento da dor; (9) criação de relações positivas entre humanos e animais e (10) assegurar habilidade e conhecimento adequados entre manipuladores de animais (FRASER et al., 2013). Atendendo a esses princípios, é relevante destacar que o BEA deve ser avaliado e reformulado de acordo com as necessidades de cada espécie.

Os bovinos são animais cujas necessidades podem ser fornecidas com relativa facilidade. A aplicação de boas práticas de gestão é uma ferramenta fundamental para alcançar a melhoria na eficiência do sistema de produção por reduzirem os riscos e melhorar o bem-estar do gado em diferentes etapas da cadeia de produção. Alguns dos riscos mais evidentes nos sistemas tradicionais de produção de carne bovina são: problemas no parto, morbidade e mortalidade de bezerros, falta de sombra nas pastagens, infraestrutura inadequada e más práticas de manejo durante o processamento de rotina (marcação, castração, vacinação, descorna). Outros fatores de risco estão relacionados ao alojamento, o tipo de piso, o número de dispensadores de água, as instalações de manuseio e a falta de movimentação específica. As condições microclimáticas podem ser críticas, dependendo da raça e localização da criação, quando o gado pode sofrer por estresse. O plano de alimentação adotado pode ser outro fator que afeta negativamente o bem-estar desses animais, devido ao baixo conteúdo de volumoso aumentando o risco de acidose metabólica (COZZI et al., 2009; DA COSTA e MORALES, 2011; M'HAMDI et al., 2012).

Apesar dos caprinos serem considerados animais rústicos, do ponto de vista bioclimático, a associação entre elevadas temperaturas, umidade e radiação solar pode acarretar alterações fisiológicas, hematológicas, hormonais, reprodutivas e produtivas (DE LIMA; FILHO, 2013). Assim, para aumentar a produtividade em regiões tropicais, é recomendada a criação de raças que apresentem maior potencial genético de adaptabilidade para uma condição climática adversa, sendo capazes de sobreviver, reproduzir e produzir em situações de estresse térmico. Promover a adequação das práticas de manejo em horários do dia e período do ano mais favorável quanto ao clima, considerando além da produtividade, constitui-se em medida essencial para manutenção do bem-estar para essa espécie (SOUZA et al., 2012).

Quanto à espécie ovina, o mercado de carne apresenta-se em crescimento, especialmente nos países em desenvolvimento. Ao lado de mercados estabelecidos, esses consumidores têm exigido uma melhor qualidade dos produtos e estão cientes de como os 
animais são criados e abatidos. Assim como em outras espécies de produção uma série de circunstâncias anteriores ao abate podem ser estressantes e causarem alterações fisiológicas levando a um efeito prejudicial sobre a qualidade final da carne ovina, com a perda de componentes que afetam a cor e textura da mesma. Características específicas do comportamento ovino, como a presença de lesões e vocalizações são associadas à diminuição das condições de bem-estar (MOURA et al., 2017).

No que diz respeito ao setor avícola, a produção de frangos cresceu em todo o mundo ao longo do século XX, se tornando uma das três principais proteínas de origem animal consumidas mundialmente ao lado da carne suína e bovina (ABPA, 2019). Em criações de galinhas poedeiras e frangos de corte, embora os animais pertençam à mesma espécie, Gallus gallus domesticus, diferenças nas pressões de seleção genética, sistemas típicos de alojamento e idade de abate resultam em diferentes questões de bem-estar social. Em frangos, o bem-estar depende não apenas da saúde física, mas também da saúde psicológica, por isso a dificuldade de avaliação e a necessidade da observação de vocalizações e posturas comportamentais (NEWBERRY; TARAZONA, 2011). Um estudo ao avaliar a sujidade das aves como indicador de bem-estar das galinhas (Gallus gallus domesticus) verificou que a dermatite de contacto na área das patas e do abdomen são dois indicadores que podem ser correlacionados aos riscos de problemas relevantes da carcaça, os quais podem ser identificados em escalas de comprometimento para avaliar o bem-estar dos frangos de corte, uma vez que são problemas prevalentes e que exigem medições aceitáveis (SOUZA et al., 2018).

$\mathrm{Na}$ suinocultura, a Europa gerou os principais estudos sobre o bem-estar suíno, estabelecendo tradição de política pública sobre o assunto, que é um dos principais intervenientes no mercado de carne suína, tornando suas normas referências para muitos países. Por estas razões, a Europa fornece o melhor modelo de estudo para o estabelecimento do bem-estar na suinocultura do Brasil (DIAS et al., 2015), onde vários parâmetros são avaliados em conjunto e auxiliam na padronização de critérios para melhoria do manejo de suínos ao longo de toda a cadeia produtiva (BRANDT; AASLYNG, 2015).

A maioria dos estudos nessa espécie sobre o bem-estar, referem-se às condições de alojamento desses animais em várias fases da produção. Ao se mensurar aspectos do bemestar de porcas gestantes alojadas em grandes grupos ou em gaiolas convencionais, verificouse que o estresse de fêmeas suínas alojadas em gaiolas era maior, encontrando-se uma maior incidência de claudicação e alterações hematológicas de estresse a partir da $9^{\mathrm{a}}$ semana de gestação (KARLEN et al., 2007). 
Em todos os animais de produção de carne, o bem-estar animal no dia do abate é uma preocupação crescente para as autoridades e consumidores (BRANDT; AASLYNG, 2015), já que o momento pré-abate gera alterações de bem-estar, principalmente com relação às formas de condução dos animais ao abate propriamente dito (GRANDIN, 2014). Por isso que estratégias para reduzir o estresse pré-abate têm sido estudadas a fim de beneficiar a qualidade da carcaça e da carne (VELARDE et al., 2015). Instalações adequadamente projetadas para carga e descarga de animais, assim como pessoal bem treinado no manuseio destes em frigoríficos desempenham um papel fundamental na determinação dos efeitos do estresse pré-abate em suínos. Melhorias na padronização de ferramentas de manipulação juntamente com o modelo das instalações e dos caminhões, ajudariam a garantir melhor bemestar de animais direcionados ao abate (GOUMON; FAUCITANO, 2017).

Além disso, os animais não devem permanecer nas baias de espera por mais de 3 horas (SANTIAGO et al., 2012) e durante esse período é necessária a utilização de sistema intermitente de aspersão de água, com intervalos de 30 minutos, respeitando o binômio temperatura e umidade relativa do ar, garantindo melhor bem-estar animal (CENTURIÓN, 2012). A preocupação com esta fase se refere aos casos de mortalidade, a qual pode chegar e suínos a 64,5\%, dependendo da estação do ano (JÜHLICH, 2016).

Por esta razão que a Organização Mundial de Sanidade Animal (OIE) define os padrões mínimos básicos de bem-estar sobre o transporte e abate de animais para controle de doenças, que cada país deve seguir. A pontuação numérica é usada tanto pela indústria privada quanto por alguns governos para acessar o bem-estar animal em plantas de abate. As cinco variáveis medidas são: 1) percentual de animais efetivamente atordoados na primeira tentativa, 2) percentual insensível, 3) percentual que vocaliza (mugido, guincho) durante o manejo e atordoamento, 4) percentual de animais que caem durante o manuseio e 5) percentual movido com um aguilhão elétrico. Um bom sistema de auditoria de bem-estar animal pró́be práticas como arrastar, derrubar, arremessar e içar animais vivos antes do procedimento de abate (GRANDIN, 2017).

A preocupação com o bem-estar não se restringe somente aos animais produtores de carne. Segundo o Australian Animal Welfare Standards and Guidelines (2014), em maio de 2008, a indústria australiana de lã começou a ser orientada por um Código de Boas Práticas para o Bem-Estar na Produção de Lã, a fim de especificar os padrões mínimos de manejo para manter o bem-estar de ovelhas alojadas para a produção de lã e fornecer diretrizes da indústria para produtores. Ovelhas mantidas presas têm prejuízo ao bem-estar, já que se 
tornam incapazes de se exercitarem o suficiente e são tipicamente isoladas de outros animais do rebanho.

$\mathrm{Na}$ piscicultura, a densidade de animais e a qualidade da água se constituem em fatores imprescindíveis na determinação do bem-estar e no desenvolvimento de peixes, onde concentrações altas de nitrogênio e nitrato são associadas a doenças crônicas que comprometem o bem-estar desses animais (DAVIDSON et al., 2014). Já na produção de salmão do Atlântico em sistemas de recirculação observa-se que a manutenção de temperaturas em torno de $13{ }^{\circ} \mathrm{C}$, bem como $>85 \%$ de saturação de oxigênio dissolvido e velocidade da água, são condições imprescindíveis para a taxa de sobrevivência, crescimento e indicadores fisiológicos de bem-estar (KOLAREVIC et al., 2014).

\section{BEM-ESTAR ANIMAL E SEU IMPACTO NA CIÊNCIA}

A detecção automática de estados comportamentais relevantes associados ao comprometimento do bem-estar social tem recebido maior atenção mundialmente e tem sido tema de pesquisas nos últimos anos (MAPA, 2017; WINCKLER, 2019). Cientistas de vários setores da sociedade enfrentam o desafio comum de aplicar a ciência para orientar políticas e práticas para o Bem-Estar Animal (BEA), muitas vezes por questões empíricas e éticas (FRASER, 2010).

A ciência do bem-estar animal não só fornece informações sobre os aspectos fisiológicos e comportamentais. Sob o ponto de vista ético há diferenças em como as pessoas veem o valor moral dos animais, e que levarão a diferentes percepções de como os humanos devem tratá-los, sobre suas reais necessidades e os interesses das pessoas envolvidas que podem levar a dilemas éticos (WSAVA, 2018). Atividades de pesquisa e ensino de bem-estar animal vêm ganhando força à medida que as indústrias agrícolas e varejistas de alimentos redigem diretrizes e implementam programas de auditoria de BEA. Os etologistas que estudam o comportamento animal sob o ponto de vista científico, tem desempenhado um papel importante nos avanços dessas pesquisas (MENCH, 2008).

Nesse sentido, aliados aos resultados obtidos na pesquisa científica, a economia e outras ciências sociais também podem desempenhar um papel importante na determinação de projetos e medidas para a melhoria do BEA, como a utilização de rotulagem para melhor escolha de produtos pelo consumidor. Desta forma, análises econômicas com base na 
opinião pública, podem orientar normas de legislação, de modo a definir padrões mínimos decentes de BEA (CHRISTENSEN et al., 2019).

Com o aumento da demanda por alimentos de origem animal um fator importante a ser considerado são as doenças endêmicas em sistemas de produção e que podem ter um impacto negativo sobre o bem-estar dos animais de fazenda, representando uma barreira à aceitação pelo consumidor. Essa realidade faz com que haja uma necessidade crescente em desenvolver políticas relativas à sanidade na produção animal, intensificação sustentável e bem-estar animal que atendam às prioridades do consumidor (CLARK et al., 2017).

Esquemas de certificação que visam fornecer uma garantia de BEA têm sido desenvolvidos em muitos países, mas não há um mecanismo acordado para o reconhecimento da equivalência dos regimes de bem-estar animal ao nível internacional. A falta de padronização nessa certificação de animais criados em níveis especificados de bemestar é uma complicação no comércio internacional (MAIN et al., 2014). É provável que o BEA quando é integrado dentro de um conceito mais amplo como garantia de qualidade ou esquemas de sustentabilidade seja melhorado e os produtos mais valorizados pelos consumidores (VERBEKE, 2009).

No Brasil, a maioria dos consumidores não possui conhecimento suficiente sobre as questões relacionadas ao bem-estar dos animais, porém acreditam que uma criação diferenciada pode resultar em melhorias no produto final.

O maior conhecimento sobre as questões que envolvem o BEA vem aumentando rapidamente nos últimos anos e tem sido objeto de considerável atenção da mídia internacional e principalmente tem gerado encontros em países da Europa e conferências na América Latina para discutir as atualizações sobre o tema, já que nesses países há a presença dos três principais sistemas de produção animal reconhecidos no mundo: o industrial ou intensivo (aves, suínos e em menor escala outras espécies); o de pastar com seus grandes fins (extensivo, semi-intensivo e rotacional); e sistemas mistos que combinam agricultura, manejo florestal e outros ecossistemas naturais com atividades pecuárias (EUROPEAN COURT AUDITORS, 2018).

\section{CONSIDERAÇÕES FINAIS}

O aumento dos estudos acerca do bem-estar animal em todo mundo reflete não só a preocupação com as condições de saúde física e mental a que os animais de companhia são 
submetidos como também dos animais de produção. No caso destes há uma repercussão negativa não só para a vida desses animais individualmente, em coletivo e também sob o ponto de vista da interferência na produtividade e qualidade de alimentos de origem animal.

No entanto, muitos estudos ainda são necessários a fim de conhecer as melhores condições de bem-estar para cada espécie animal, para que se possam principalmente definir ações que permitam alterações benéficas na forma de criação e convivência saudável, respeitando as características e necessidades específicas dos animais.

\section{REFERÊNCIAS}

AZEVEDO, C.S.; BARÇANTE, L. Enriquecimento ambiental em zoológicos brasileiros: em busca do bem-estar animal. Zoociências 19 (2): p15-34, 2018.

WELLS, D.L. The influence of toys on the behaviour and welfare of kennelled dogs. Animal Welfare., 13, pp. 367-373, 2004.

CHÁVEZ, G.; UBILLA, M.J. Conceptos generales y epidemiología de los problemas de comportamiento en perros. In: Chávez, G. (Ed.), Etología clínica veterinaria del perro. Guía práctica de abordaje para médicos veterinarios, Viña del Mar, Chile. En RIL editores, pp. 27 e $25,2014$.

ASSOCIAÇÃO BRASILEIRA DE PROTEÍNA ANIMAL (ABPA). A História da Suinocultura no Brasil. Disponível em : http://abpa-br.com.br/setores/suinocultura. Acesso em fevereiro de 2019.

AUSTRALIAN ANIMAL WELFARE STANDARDS AND GUIDELINES - SHEEP DECISION REGULATION IMPACT STATEMENT. 2014. 127p. $1 \circ$ ed. Disponível em: http://www.animalwelfare standards.net.au. Acesso em: 15 de dezembro de 2018.

AVERÓS, X; APARICIO, M.A.; FERRARI, P; GUY, J.H.; HUBBARD, C.; SCHMID, O; ILIESKI, V.; SPOOLDER, H.A.M. The Effect of Steps to Promote Higher Levels of Farm Animal Welfare across the EU. Societal versus Animal Scientists' Perceptions of Animal Welfare. Animals, v.3, p.786-807, 2013.

BOYD, C; JMCGREEVY, P.D.; HEATH, S; CHURCH, D.B; BRODBELT, D.C; O'NEILL, D.G. Mortality resulting from undesirable behaviours in dogs aged under three years attending primary-care veterinary practices in England. Animal Welfare, v.27, n.3, p.251-262(12), 2018.

BRACKE, M. B. M; HOPSTER, H. Assessing the Importance of Natural Behavior for Animal Welfare. Journal of Agricultural and Environmental Ethics, v.19, n.1, p.77-89, 2006.

BRANDT, P; AASLYNG, M.D. Welfare measurements of finishing pigs on the day of slaughter: A review. Meat Science, v.103, p. 13-23, 2015. 
BROOM, D.M.; MOLENTO, C.F.M. Bem-estar animal: conceito e questões relacionadas Revisão. Archives of Veterinary Science, v.9, n.2, p.1-11, 2004.

BROOM, D. M. Bem-estar animal. In: Comportamento Animal, 2a ed., Yamamoto, M.E. and Volpato, G.L., Natal; Editora da UFRN, 2011: 457-482.

CANNON, MARTHA; RODAN, ILONA; The Cat in the Veterinary Practice. In: HEATH, SARAH; RODAN, ILONA. Feline Behavorial Wealth and Welfare. 3251 Riverport Lane/St. Louis, Missouri: Elsevier, p. 102-111, 2016.

CENTURIÓN, R. A. O. Ambiente térmico e bem-estar de suínos no período de descanso pré-abate. 2012. 47p. Dissertação ((Mestrado em Zootecnia) - Universidade Federal da Grande Dourados, Dourados, MS, 2012.

CHRISTENSEN, T; DENVER, S; SANDØE, P. How best to improve farm animal welfare? Four main approaches viewed from an economic perspective. Animal Welfare, v. 28, n.1, p.95-106 (12), 2019.

CLARK, B; STEWART, G. B; PANZONE, L. A; KYRIAZAKIS, I; FREWER, L.J. Citizens, consumers and farm animal welfare: A meta-analysis of willingness-to-pay studies. Food Policy, v.68, p.112-127, 2017.

CORNISH, A; RAUBENHEIMER, D; MCGREEVY, P. What We Know about the Public's Level of Concern for Farm Animal Welfare in Food Production in Developed Countries. Animals. v.6, p.1-15. 2016.

COZZI, G; BRSCI, M; GOTTARDO, F. Main critical factors affecting the welfare of beef cattle and veal calves raised under intensive rearing systems in Italy: a review. Ital. J. Anim. Sci., v. 8 (Suppl. 1), p.67-80, 2009.

DA COSTA, M.J.R.P; MORALES, A.M.T. Practical approach on how to improve the welfare in cattle. Rev. Colomb. Cienc. Pecu 2011: 24:3, p. 347-359, 2011.

DAVIDSON, J; GOOD, C; WELSH, C; SUMMERFELT, S. T. Comparing the effects of high vs. low nitrate on the health, performance, and welfare of juvenile rainbow trout Oncorhynchus mykiss within water recirculating aquaculture systems. Aquacultural Engineering, v. 59, p. 30-40, 2014.

DE LIMA, L.R; FILHO, J.A.D.B. Impacto do manejo pré-abate no bem-estar de caprinos e ovinos. J Anim Behav Biometeorol, v.1, n.2, p.52-60, 2013.

DIAS, C.P; DA SILVA, C.A; MANTECA, X. The brazilian pig industry can adopt european welfare standards: a critical analysis Ciência Rural Santa Maria, v.45, n.6, p.1079-1086, 2015.

EUROPEAN COURT AUDITORS (ECA). Animal welfare in the EU: closing the gap between ambitious goals and practical implementation. 68p, 2018. Disponível em: https://www.eca.europa.eu/Lists/ECADocuments/SR18 31/SR ANIMAL WELFARE _EN.pdf. Acesso em: 22 de janeiro de 2019.

FARM ANIMAL WELFARE COUNCIL (FAWC). Annual Review 2009-2010. UK., 2010. 
FRASER, D. Toward a synthesis of conservation and animal welfare science. Animal Welfare, v.19, n.2, p.121-124, 2010.

FRASER, DAVID; DUNCAN, I.J.H.; EDWARDS, S. A.; GRANDIN, T; GREGORY, N. G; GUYONNET, V; HEMSWORTH, P. H; HUERTAS, S. M.; HUZZEY, J. M; MELLOR, D. J; MENCH, J. A; ŠPINKA, M; WHAY, H. R. General Principles for the welfare of animals in production systems: The underlying science and its application. The Veterinary Journal, v. 198, n.1, p.19-27, 2013.

GOUMON, S; FAUCITANO, L. Influence of loading handling and facilities on the subsequent response to pre-slaughter stress in pigs. Livestock Science, v.200, p.6-13, 2017.

GRANDIN T. Animal welfare and society concerns finding the missing link. Meat Science. v.98, p.461-469, 2014.

GRANDIN, T. On-farm conditions that compromise animal welfare that can be monitored at the slaughter plant. Meat Science, v. 132, p. 52-58, 2017.

HEMSWORTH, P.H; MELLOR, D.J; CRONIN, G.M; TILBROOK, A.J. Scientific assessment of animal welfare. New Zealand Veterinary Journal, v.63, n.1, p. 24 -30, 2015.

HEMSWORTH, P.H; MELLOR, D.J; CRONIN, G.M; TILBROOK, A.J. Scientific assessment of animal welfare. New Zealand Veterinary Journal, v.63, n.1, p. 24 -30, 2015.

JÜHLICH, L. M. Causas de morte em suínos no período pré-abate. 2016. 50p. Dissertação (Programa de Pós-Graduação em Ciências Veterinárias), Universidade Federal do Rio Grande do Sul, Porto Alegre, 2016.

KARLEN, G. A. M; HEMSWORTH, P. H, GONYOU, H. W; FABREGA, E. Strom A D, Smits R J. The welfare of gestating sows in conventional stalls and large groups on deep litter. Applied Animal Behaviour Science. v.105, p.87-101, 2007.

KILBRIDE, A. L; MENDL, M; STATHAM, P; HELD, S; HARRIS, M; MOIRA \& MARCHANT-FORDE, J.N; BOOTH, H; GREEN, L. E. Risks associated with preweaning mortality in 855 litters on 39 commercial outdoor pig farms in England. Preventive Veterinary Medicine v.117, p. 189-199, 2014.

KOLAREVIC, J; BAEVERFJORD, G; TAKLE, H; YTTEBORG, E; REITEN, B. K. M; NERGÅRD, S; TERJESEN, B. F. Performance and welfare of Atlantic salmon smolt reared in recirculating or flow through aquaculture systems. Aquaculture, v. 432, p. 15-25, 2014.

LADEWIG, J. The role of the veterinarian in animal welfare. Acta Veterinaria Scandinavica v.50 (Suppl 1): S5, p. 10-11, 2008.

LINHARES, V.L.V; SILVA, M.C.; SILVA, A.M.; BEZERRA, D.R. O adestramento positivo como tratamento em cães com distúrbios comportamentais de ansiedade: Relato de casos. PUBVET v.12, n.4, a61, p.1-9, 2018

M'HAMDI, N; FROUJA, S; BOUALLEGUE, M; ALOUlOU, R; BRAR, S. K; HAMOUDA, M. B. In: Milk Production an up to date overview of animal nutrition 
management and health. Chapter 14, p. 289-308, 2012. Disponível em:< https://www.intechopen.com/books/milk-production-an-up-to-date-overview-of-animalnutrition-management-and-health/dairy-cattle-welfare-status-measured-by-animal-linkedparameters-under-tunisian-rearing-conditions > . Acesso em: 20 de janeiro de 2019.

MAIN, A. D.C.J; MULLAN, S; ATKINSON, C; COOPER, M; WRATHALL, J.H.M; BLOKHUIS, H.J. Best practice framework for animal welfare certification schemes. Trends in Food Science \& Technology v.37, p.127-136, 2014.

MENCH, J.A. Farm animal welfare in the U.S.A.: Farming practices, research, education, regulation, and assurance programs. Applied Animal Behaviour Science, v.113, n.4, p. 298-312, 2008.

MEYER-HAMME, S.E.K; LAMBERTZ, C.; GAULY, M. Assessing the welfare level of intensive fattening pig farms in Germany with the Welfare Quality ${ }^{\circledR}$ protocol: does farm size matter? Animal Welfare (12), v.27, n.3, p.275-286, 2018.

MINISTÉRIO DA AGRICULTURA PECUÁRIA E ABASTECIMENTO (MAPA). Coordenação de Boas Práticas de Bem-Estar Animal, p.1-2, 2017. Disponível em: <http: www.agricultura.gov.br/assuntos/boas-/praticas-e-bem-estar-animal. Acesso em: 07 de março de 2019.

MIRANDA-DE LA LAMA, G. C; ESTÉVEZ-MORENO, L.X; SEPÚLVEDA, W. S; ESTRADA-CHAVERO, M.C; RAYAS-AMOR, A.A; VILLARROEL, M; MARÍA, G. A. Mexican consumers' perceptions and attitudes towards farm animal welfare and willingness to pay for welfare friendly meat products. Meat Science, vol. 125, p. 106-113, 2017.

MIRANDA-DE LA LAMA, G. C; SEPÚLVEDA, W. S; VILLARROEL, M; MARÍA, G. A. Attitudes of meat retailers to animal welfare in Spain. Meat Science, v. 95, n.3, p. 569$575,2013$.

MOURA, S. V; FELIX, S. R; SILVA, E. F. Correlation of sheep welfare and behavior with meat quality: a review. Science and Animal Health, v.5, n.1, p. 57-70, 2017.

NEWBERRY, R. C; TARAZONA, A. M. Behavior and welfare of laying hens and broiler chickens. Rev. Colomb. Cienc. Pecu 24: 301-302, 2011.

OHL, F; VAN DER STAAY, F.J. Animal welfare: At the interface between science and society. The Veterinary Journal, v. 192, n.1, p. 13-19, 2012.

OLIVEIRA, C. B; BORTOLI, E. C; BARCELLOS, J. O. J. Diferenciação por qualidade da carne bovina: a ótica do bem-estar animal. Ciência Rural. v.38, n.7, p.2092-2096, 2008.

ORGANIZAÇÃO MUNDIAL DE SANIDADE ANIMAL (OIE). Estratégia Mundial de Biene Estar Animal de La OIE, 2017. Disponível em: <http:www.oie.int/bienestaranimal.com>. Acesso: 18 de dezembro de 2018.

PAQUET, P.C; DARIMONT, C.T. Wildlife conservation and animal welfare: two sides of the same coin? Animal Welfare v.19, p. 177-190, 2010. 
PEDRAZZANI, A S, MOLENTO, C. F. M, CARNEIRO, P. C. F; CASTILHO, M. F. Senciência e bem-estar de peixes: uma visão de futuro do mercado consumidor. Panorama da aquicultura. 2007: p. 24-29.

QUEIROZ, M. L. V; FILHO, J. A.D. B; ALBIERO, D; BRASIL, D. F; MELO, R. P. Percepção dos consumidores sobre o bem-estar dos animais de produção em Fortaleza, Ceará. Revista Ciência Agronômica, v. 45, n. 2, p. 379-386, 2014.

RODAN, I. Importance of Feline Behavior in Veterinary Practice. In: HEATH, SARAH; RODAN, ILONA. Feline Behavorial Health and Welfare. St. Louis Missouri: Elsevier, p. 2-08, 2016.

ROSE, N. A; SNUSZ, G. H; BROWN, D. M; PARSONS, E. C. M. Improving Captive Marine Mammal Welfare in the United States: Science-Based Recommendations for Improved Regulatory Requirements for Captive Marine Mammal Care. Journal of International Wildlife Law \& Policy, v.20, n.1, p.38-72, 2017.

SANTIAGO, J. C; CALDARA, F. R; SANTOS, V. M; SENO, L. O; GARCIA, R. G; ALMEIDA PAZ, I. C. Incidência da carne PSE (pale, soft, exsudative) em suínos em razão do tempo de descanso pré-abate e sexo. Arquivo Brasileiro de Medicina Veterinaria e Zootecnia, v.64, p. 1739-1746, 2012.

SILVA, D.S. Monografia apresentada à faculdade de Veterinária como requisito parcial para obtenção da Graduação em Medicina Veterinária (2017). Universidade Federal do Rio Grande do Sul. 45p.

SILVA, L.F; MENEZES, J. V. D.T; DOS SANTOS, T. M.B. Protocolo para avaliação do bem-estar de cães terapeutas. In: $55^{\circ}$ Reunião Anual da Sociedade Brasileira de Zootecnia. Centro de Convenções PUC-Goiania, p. 1-5, 27 a 30 de agosto de 2018.

SMITH, R P, CORREIA-GOMES, C.; WILLIAMSON, S.; MARIER, E.A.; GILSON, D.; TONGUE, S.C. Review of pig health and welfare surveillance data sources in England and Wales. Veterinary Record. 2019; p.1-12, 2019.

SOUZA, A; SORIANO, V.S; SCHNAIDER, M.A; RUCINQUE, D.S; MOLENTO, C.F.M. Development and refinement of three animal-based broiler chicken welfare indicators. Animal Welfare, v.27, n.3, p.263-274(12), 2018.

SOUZA, P. T; SALLES, M. G. F; DE ARAÚJO, A. A. Impacto do estresse térmico sobre a fisiologia, reprodução e produção de caprinos. Ciência Rural, v.42, n.10, p.1888-1895, 2012.

TÖNEPÖHL, B.; APPEL, A. K. ; VOSS, B.; BORSTEL, U. K. VON; GAULY, M. Interaction between sows' aggressiveness post mixing and skin lesions recorded several weeks later. Applied Animal Behaviour Science, v. 144, n.3-4, p. 108-115, 2013.

VELARDE, A; FÀBREGA, E; BLANCO-PENEDO, I; DALMAU, A. Animal welfare towards sustainability in pork meat production. Meat Science v.109, p. 13-17, 2015.

VERBEKE, W. Stakeholder, citizen and consumer interests in farm animal welfare. Animal Welfare v.18, p. 325-333, 2009. 
WILLIAMS, E; CHADWICK, CL; YON, L; ASHER, L. A review of current indicators of welfare in captive elephants (Loxodonta africana and Elephas maximus). Animal Welfare, v.27, n.3, p. 235-249(15), 2018.

WINCKLER, C. Assessing animal welfare at the farm level: do we care sufficiently about the individual? Animal Welfare, v.28, n.1, p. 77-82(6), 2019.

WSAVA Global Veterinary Community. Animal Welfare Guidelines for companion animal practitioners and veterinary teams. 80p. 2018. Disponível em: https://www.wsava.org/WSAVA/media/Documents/General\%20PDFs/WSAVA Anim al Welfare Guidelines.pdf. Acesso em: 20 de janeiro de 2019.

ORGANIZAÇÃO MUNDIAL DE SANIDADE ANIMAL (OIE). Código Sanitário de Animais

http:/ /www.oie.int/index.php?id=169\&L=0\&htmfile=chapitre_aw_land_transpt.htm $>$ Acesso em: 15 novembro 2018. 


\section{BEM ESTAR ANIMAL NO TRANSPORTE DE BOVINOS}

\section{Andressa Tronquini Rossi}

Universidade Cândido Mendes, Pós-Graduação do Ifope Educacional, Rio de Janeiro, Rio de Janeiro

\section{Loana Rangel Bertolino}

Fiscal Agropecuária do Instituto Mineiro de Agropecuária, Belo Horizonte, Minas Gerais

\section{Lina Raquel Santos Araújo}

Universidade Estadual do Ceará, Faculdade de Veterinária, Fortaleza, Ceará http://lattes.cnpq.br/7591378438576586

Informações sobre o

artigo:

Recebido em:

$30 / 08 / 2020$

Aceite em:

$31 / 08 / 2020$

Data de publicação:

$05 / 10 / 2020$

Palavras-chave:

Comportamento

Estresse

Inibidores

Manejo

\section{RESUMO}

O crescimento da agricultura no Brasil com a valorização do bemestar em animais de produção é um tema que está diariamente conectado com a sociedade. O transporte é uma etapa muito importante que afeta a saúde dos animais e a qualidade do produto final. Assim a perfeição no manejo durante o deslocamento rodoviário está diretamente engajada com a preocupação do bemestar. As ações como embarque, transporte e desembarque são fatores importantes como prevenção da boa saúde, pois as condições físicas e psicológicas dos animais são essenciais para manter uma boa qualidade e integralidade da carcaça. Os animais devem expressar seu comportamento de forma natural em todo o trâmite. Esta revisão bibliográfica tem o propósito de apresentar os principais conceitos e alguns indicadores relacionados ao bemestar animal, mais especificadamente ao grupo dos bovinos.
Keywords:

Behavior

Indicators

Management

Stresses

\section{WELFARE OF CATTLE DURING TRANSPORT}

\section{ABSTRACT}

The growth of agriculture in Brazil with the enhancement of welfare in farm animals is a theme that is daily connected with society. Transport is a very important step that affects the health of animals and the quality of the final product. Perfection in handling during road transport is directly involved with the concern for well-being. Actions such as boarding, transport and disembarkation are important factors in preventing good health, as the physical and psychological conditions of the animals are essential to maintain a good quality and integrity of the carcass. Animals must express their behavior in a natural way throughout the procedure. This bibliographic review aims to present the main concepts and some indicators related to animal welfare, more specifically to the group of cattle. 


\section{INTRODUÇÃO}

De acordo com a Organização Mundial da Saúde Animal (OIE, 2017), o bem-estar animal pode ser definido como a preocupação e conscientização do homem acerca das condições nas quais o animal está sendo criado, o bem-estar visa a melhorias fisiológicas nos animais desde a entrada nos sistemas de produção até o abate. É considerado que o animal encontra-se em bem-estar quando este tem boa saúde, conforto, está adequadamente nutrido, seguro e seja capaz de expressar seu comportamento inato, além da ausência de sofrimento, dor, medo e angústia.

Para atingir o bem-estar animal ideal é necessário que os profissionais da saúde animal trabalhem continuamente na promoção da prevenção de doenças, na utilização de tratamentos veterinários apropriados, que os animais sejam abrigados e manipulados em locais seguros e adequados, recebam alimentação e água de qualidade e que o abate ou sacrifício sejam realizados de forma humanitária. As práticas de saúde e bem-estar devem estar ligadas diretamente ao estado físico e moral do animal, ou seja, qualquer tratamento dado em espécies como bovinos, suínos, bubalinos, caprinos, ovinos e aves, devem ser propiciados através do tratamento humanitário (OIE, 2017).

Os bovinos são animais rotineiros, dotados de uma boa memória e capazes de reconhecer seus tratadores e apresentar reações específicas a cada tipo de tratamento recebido (PARANHOS DA COSTA, 2002). O embarque de bovinos deve ser realizado de forma segura precavendo e reduzindo a possibilidade de contusões e lesões físicas, que ocorrem principalmente nos membros inferiores (BERTOLONI et al. 2012). Também deve ser observado o tipo de manejo local para que não apresente qualquer irregularidade. $\mathrm{O}$ uso inadequado de cães condutores ou chicotes elétricos pode acarretar mal estar, gerando contusões e crises emocionais aos animais. Toda mudança inadequada de ambiente pode causar estresse aos bovinos e se manipulados de forma rude, acarreta má qualidade de suas carcaças e pode reduzir o tempo de prateleiras de seus produtos (BURNS, 2019). Neste sentido, o presente estudo tem como objetivo abordar o transporte de bovinos, discutindo as problemáticas que envolvem a atividade pecuária do embarque até frigoríficos ou fazendas. 


\section{O BEM-ESTAR: AS 5 LIBERDADES}

O Bem-estar animal é um termo que diz respeito tanto ao físico quanto ao mental. Os princípios de bem-estar animal começaram a ser abordados oficialmente em 1965, no Reino Unido, por uma comissão técnica multidisciplinar nomeada pelo governo britânico de Comitê Brambell, que estabeleceu as cinco liberdades (COELHO et al., 2017):

1. Liberdade fisiológica: ausência de fome e sede. A alimentação à disposição do animal deve ser suficiente, tanto em quantidade quanto em qualidade, permitindo crescimento, vigor e saúde normais.

2. Liberdade ambiental: ausência de desconforto, térmico ou físico. As instalações e/ou edificações devem ser adaptadas, fazendo com que o ambiente não seja excessivamente quente ou excessivamente frio, nem impeça o descanso e atividades normais.

3. Liberdade sanitária: ausência de injúrias e doenças. As instalações devem apresentar-se de forma a minimizar o risco de doenças, fraturas e machucados e quaisquer casos que ocorram devem ser reconhecidos e tratados sem demora.

4. Liberdade comportamental: possibilidade para expressar padrões de comportamento normais. O ambiente deve permitir e oferecer condições para que o animal expresse seus instintos e comportamentos normais, inerentes à sua espécie.

5. Liberdade psicológica: ausência de medo e ansiedade. O animal não deve ser exposto a situações que lhe provoquem angústia, ansiedade, medo ou dor.

Esses cinco itens procuram oferecer uma abordagem para a compreensão do bemestar como ele é percebido pelo próprio animal (e não como definido por seu criador ou mesmo pelo consumidor) e servem como um ponto de partida para avaliar os aspectos bons e ruins de um sistema de criação (WEBSTER, 1987).

\section{INDICADORES DE ESTRESSE}

Os animais podem sofrer de estresses psicológicos, seja por medo de embarcar ou desembarcar de um veículo, ou por restrição alimentar, passando fome, sede, ou por constante manuseio ocasionando fadiga, lesões ou até mesmo elevação temperatura corporal, ocasionando negativas ao bem-estar animal. O indicador mais apropriado de bem-estar animal seria a ausência de estresse e sofrimento. Muitas vezes, os padrões de comportamento 
são reflexos das tentativas do animal de se libertar ou escapar de agentes e estímulos estressantes (GLASER, 2003).

O bem-estar pode ser avaliado por meio de características fisiológicas e comportamentais, assim diante da elevação de fatores estressores poderão ser observadas alterações fisiológicas e comportamentais (GLASER, 2003). O mesmo estudo reafirma a existência de fatores exógenos provedores de estresses, como calor, frio, umidade, fome, sede, infecções, parasitas, injúrias físicas, ambiente inadequado, dor, elevada densidade populacional, isolamento, situações que levam ao medo e/ou ansiedade, entre outros.

O fator de manejo é um importante ponto para o equilíbrio e conforto de bovinos nos sistemas de produção e outro fator que merece destaque é a densidade populacional, que está intimamente relacionada ao espaço vital e a reestruturação da hierarquia social quando se misturam lotes de diferentes origens em uma mesma baia geram situações estressantes. Em relação ao espaço de vida e a zona de fuga, ambos são proporcionalmente opostos ao aumento da densidade populacional, ou seja, um número elevado de bovinos em um determinado espaço torna-se um ponto negativo ao seu desenvolvimento, rendimento, produção e até mesmo sendo incompatível a manutenção de um período saudável de vida (POLLI et al., 1995).

Dessa forma, a expressão comportamental é de extrema importância na produção de bovinos de corte, pois tem um papel fundamental nas adaptações e funções biológicas (PAJOR et al., 2000). Um dos aspectos do comportamento bovino é a reatividade, avaliada pelas reações dos animais a diferentes situações de manejo, sendo tais reações associadas a estímulos ocasionados pela presença humana (BOIVIN et al., 1992). A reatividade é um dos aspectos do temperamento e define-se pela qualidade ou estado daquele que protesta ou luta, sendo sua expressão dependente de vários componentes como, por exemplo, a intensidade do estímulo e o significado do estímulo para o indivíduo, a motivação e a intensidade de resposta (PIOVEZAN, 1998).

Os níveis de estresse, como já citados, são utilizados como o principal parâmetro para avaliar o bem-estar animal. Se estes animais desenvolverem estresses terão mecanismos de resposta, e sua homeostasia estará ameaçada, e assim o animal irá precisar de novos mecanismos para adaptação fisiológica, de forma a adequar-se em um novo ambiente (GRANDIN, 1998). Para tal avaliação, alguns parâmetros fisiológicos como temperatura retal e corporal, frequência respiratória, frequência cardíaca e pH são importantes serem mensurados para observar a adaptação do animal àquele sistema de produção. 
A manutenção da temperatura corporal é determinada pelo equilíbrio entre a perda e o ganho de calor. A referência fisiológica dessa variável é obtida mediante a mensuração da temperatura retal, que pode variar de $38,1{ }^{\circ} \mathrm{C}$ a $39,1{ }^{\circ} \mathrm{C}$ para animais das raças de corte especializadas, de $38,0{ }^{\circ} \mathrm{C}$ a $39,3{ }^{\circ} \mathrm{C}$, para animais leiteiros (ROBINSON, 1999). A referência fisiológica para essa variável está entre 38,0 e $39,5^{\circ} \mathrm{C}$ sob condições termo neutras (DUPREEZ, 2000). A temperatura retal pode mostrar a adaptação fisiológica do animal ao ambiente, pois seu aumento indica que os mecanismos de liberação de calor tornaram-se insuficientes para manter a homeotermia (MOTA, 1997). Bacari Jr. (1987) afirmou que o calor necessário para manter a temperatura corporal dos animais deriva do metabolismo e da absorção da radiação solar, direta ou indireta, enquanto a temperatura corporal depende do equilíbrio entre o calor produzido e o liberado para o ambiente.

Outro indicativo é a frequência respiratória, com o aumento do calor e uma vez que o bovino fica ofegante, pode ocorrer menor volume do ar inspirado, o que dificultaria a troca de calor pela evaporação. (ROBERTSHAW, 2006) A frequência respiratória normal em bovinos adultos tem uma variação entre 24 e 36 movimentos respiratórios por minuto. Diante de uma condição estressante, a frequência respiratória começa a elevar-se antes da temperatura retal, e observa-se taquipneia em bovinos em ambientes com temperatura elevada (FERREIRA et al., 2006).

A frequência cardíaca para bovinos adultos, situa -se em 60 a 70 batimentos por minuto (ROSSAROLLA, 2007). Se o estresse for confirmado, e estiver com uma intensidade moderada, a frequência cardíaca será reduzida em resposta a dilatação periférica dos vasos (CERUTTI et al., 2013).

Ainda existem formas de avaliar o estresse sofrido pelo animal na fase ante mortem, como pela medição do $\mathrm{pH}$, que é mais comum e universalmente aceita como indicador da qualidade final da carne. A queda do $\mathrm{pH}$ muscular é uma das mais significantes mudanças post-mortem que ocorrem no processo de conversão do músculo em carne. Este processo envolve uma série de alterações no metabolismo e que estão relacionadas com os níveis de glicogênio muscular, que promove alterações com a queda do $\mathrm{pH}$ ou acidificação, a desnaturação de proteínas, queda da temperatura e a produção de ácido lático (COSTA et al., 2005). O que determina o valor do $\mathrm{pH}$ é a quantidade de ácido lático post mortem da carne produzido a partir do glicogênio muscular durante a glicólise anaeróbia, e isto pode ser impedido se o glicogênio for consumido por fadiga, inanição, ou pelo medo e estresse do animal antes do abate (ROÇA, 2001). Segundo Del Campo (2016), se houver um manejo inadequado aos bovinos, a carcaça, pode resultar em carnes dos tipos DFD (Dura, Firme e 
Escura) e PSE (Pálida, Mole e Exsudativa), o que leva a má aceitação por parte do mercado consumidor.

\section{CUIDADOS E BOAS PRÁTICAS NO TRANSPORTE PARA OS BOVINOS}

O transporte rodoviário de animais inclui embarque do seu local de origem, o transporte propriamente dito e o desembarque em seu destino (TARRANT; GRANDIN, 2000). O transporte inadequado é um dos fatores determinantes para o nível dos estresses dos bovinos. Chen et al. (2015) relatam que existem alguns fatores que podem contribuir para essa resposta ao estresse, incluindo interações homem-animal imediatamente antes e depois do transporte. Como o embarque e o transporte não fazem parte da rotina animal, o transporte e o manejo no frigorífico são considerados os eventos mais estressantes, o que pode afetar diretamente a qualidade da carne (GOMIDE et al., 2006).

O maior problema durante o embarque é a falta de conhecimento sobre os princípios básicos de bem-estar. Durante o manuseio e o transporte, uma pessoa pode causar altos níveis de estresse nos bovinos, enquanto outra pessoa que faz o mesmo trabalho pode causar pouco ou nenhum estresse nos animais. O tratador ou o motorista são responsáveis pelo manejo dos animais até a entrada no caminhão, e muitas vezes, a ausência de treinamento e conhecimentos básicos sobre como tratá-los, são fatores estressores aos animais. A exemplo muitos condutores utilizam ferrões e choque elétrico na tentativa de os animais subirem na rampa mais rapidamente, o que pode resultar em machucados, prejudicando a carcaça com a liberação de hormônios relacionados ao estresse na etapa ante mortem. Esse procedimento estressante pode resultar em dor, sofrimento, contusão e edemas (BARBOSA FILHO et al., 2004).

Segundo Nielsen (2011), o estresse de animais destinados ao abate se inicia justamente no momento do embarque, uma vez que, os animais saem do ambiente de criação. O transportador deve observar se os animais estão em jejum alimentar, sendo que a restrição dos alimentos pode ser considerado outro fator estressante na rotina do animal. A continuidade do processo eleva os níveis sanguíneos de cortisol, dentre outros fatores, como a alta densidade da carga, as inspeções durante o transporte, o tempo de percurso, as paradas durante o período da viagem e o descarregamento. Ao chegar no destino serão submetidos a um check list para registrar observações como presença de lesões, animais caídos, seguridade do veículo, dentre outros. 
No embarque os bovinos são estimulados a se deslocarem quando visualizam outros animais em movimentos, assim ocorra, torna-se necessário que os corredores sejam bem dimensionados proporcionando as movimentações em lotes se os corredores forem inadequados, ou muito estreitos e construídos com mudanças de direção em ângulos fechados, escuros e muito longos, isso irá dificultar o manejo dos bovinos. Lembrando que os pisos devem conter antiderrapantes para promover os deslocamentos dos animais com segurança de forma a evitar escorregões e quedas (LUDTKE et al., 2012a).

A escolha do veículo é imprescindível para que alguns problemas possam ser evitados como: carrocerias com pontas de madeira, ripas, pregos ou parafusos expostos, pisos escorregadios, altura e paredes das carrocerias inadequadas; rampa com inclinação imprópria para o transporte e condições inadequadas de ventilação (PARANHOS DA COSTA, 2000). Há alguns tipos de veículos que se diferenciam principalmente em relação aos compartimentos de carga, são eles:

1. Veículo não articulado com três eixos, geralmente conhecido como caminhão truck; com capacidade média para 18 animais (BERTOLONI et al., 2012);

2. Veículo articulado, conhecido como carreta, com um (27 animais) ou dois pisos de compartimento de carga (double deck) com capacidade média para 42 animais divididos em 6 compartimentos distribuídos em dois pisos (BERTOLONI et al., 2012);

3. Veículo duplo-articulado, conhecido como bi-trem, composto por dois compartimentos de cargas independentes, ambos com um ou dois pisos.

4. Veículos não articulados com dois eixos (conhecidos como caminhões "toco") ou veículo menores para o transporte de apenas 3 ou 4 animais.

Carretas double deck têm sido utilizadas na tentativa de reduzir custos com o deslocamento dos animais, no entanto, tal prática pode gerar efeitos negativos sobre a carcaça dos animais transportados como uma maior incidência de hematomas (BERTOLONI et al., 2012). É mais difícil embarcar e desembarcar bovinos em veículos com compartimentos de carga com dois pisos. Isto porque o acesso ao segundo piso é geralmente feito por rampas muito inclinadas, que dificultam a subida e descida dos animais. Nesses casos os procedimentos de embarque devem ser realizados com muito mais atenção e cuidado, de forma a minimizar os problemas (LUDTKE et al., 2012b).

Neste sentido, segundo Bertoloni et al. (2012), considerando condições e os indicadores de bem-estar animal e qualidade de carcaça avaliados, concluíram que o caminhão tipo truck e a carreta tipo baixa apresentam melhores resultados em comparação à carreta tipo double deck no transporte de bovinos. 
Os veículos deverão ter entrada de ar entre as linhas de grades dos compartimentos para promover uma ventilação suficiente para evitar o desconforto. Os veículos que são adaptados para fornecerem sombra e abrigo durante período de chuva ou mau tempo são os ideais, porém pouco utilizados nos países em desenvolvimento como o Brasil (BROOM, 2008). Outro aspecto que não podemos deixar de fora é o espaço que cada animal ocupa, ou seja, a densidade de carga. Esta pode ser classificada em alta, cuja densidade é de $600 \mathrm{~kg} / \mathrm{m}^{2}$, média $400 \mathrm{~kg} / \mathrm{m}^{2}$ e baixa $200 \mathrm{~kg} / \mathrm{m}^{2}$ (TARRANT et al., 1988).

Durante o transporte propriamente dito, se o motorista não for cauteloso e não prevenir acidentes com estes animais, podemos ter mortes, ou algum outro tipo de perda que será significativa. Estradas de chão batido e em más condições deverão ser evitadas na medida do possível, além de realizar paradas a cada 3 horas para alívio dos animais. Por isso, a forma de direção influencia a o bem-estar dos animais com melhora da qualidade da carne (GOMIDE et al., 2006)

O tempo de percurso é outro fator considerado importante, pois o tempo da viagem, de um local a outro, podem ocasionar perdas, alteração de $\mathrm{pH}$, alteração nos níveis de lactato, coloração, contusões e hematomas (BATISTA DE DEUS et al., 1999; GALLO et al., 2000; BURNS, 2019). Um maior tempo de viagem interfere no metabolismo post mortem, elevando o pH final e reduzindo os níveis de lactato no músculo 24 horas após o abate (BATISTA DE DEUS et al., 1999). Portanto o trajeto, seja pela distância ou pelo tempo na duração da viajem, pode impactar diretamente o bem-estar e a qualidade da carne bovina e seus derivados.

Não podemos esquecer do desembarque dos animais no seu destino, uma vez que, esse tipo de manuseio é mais propenso a sofrer lesões, contusões, traumas de quedas ou escorregões (BATTIFORA et al., 2000; CESAR; HUERTAS, 2014). Dessa forma, os procedimentos deverão ser basicamente os mesmos realizados durante o embarque na fazenda, ou seja, evitar o uso de bastões de choque ou ferrões para forçar os animais a descer do caminhão. É de extrema importância que logo após o desembarque no abatedouro, os animais sejam alojados no curral de espera, onde permanecerão por um tempo suficiente para que se acalmem e descansem da viagem, antes de prosseguirem para as próximas etapas do abate (PEREIRA, 2006)

E para tudo isso ser eficaz, as instalações de destino devem primeiramente proporcionar conforto e segurança aos animais, ser duradouras e econômicas, ou seja, devem ser projetadas levando em consideração as características da área, tipo de solo, topografia, disponibilidade de água e as necessidades dos animais. Uma construção eficaz, a manutenção 
e o uso correto dessas instalações além de proporcionarem condições que não coloquem em risco o bem-estar dos animais também apresentarão uma vida útil maior (OLIVEIRA FILHO, 2015).

\section{CONSIDERAÇÕES FINAIS}

O transporte tem influência significativa no bem-estar de bovinos de corte, podese então concluir que é de extrema importância que sejam utilizadas mão de obra qualificada (profissionais treinados), transporte de qualidade, escolha do tipo de caminhão, sem exposição ao calor e ao frio, utilização de materiais adequados que impeçam de feri-los ou não os leve a atingir qualquer nível de estresse. Constantes avaliações fisiológicas são de extrema importância para monitorar a qualidade de vida dos animais dentro dos sistemas de produção.

\section{REFERÊNCIAS}

BACCARI JÚNIOR., F. A temperatura corporal dos bovinos. Gado Holandês, n.51, p.1519, 1987.

BARBOSA FILHO, J.A.D.; SILVA, I.J.O da. Abate humanitário: ponto fundamental do bem-estar animal. Revista Nacional da Carne, São Paulo, v. 28, n. ju, p. 36-44, 2004.

BATISTA DE DEUS, J.C., SILVA, W.P. da; SOARES, G.J.D. Efeito da distância de transporte de bovinos no metabolismo post mortem. Revista Brasileira de Agrociência, v.5 no 152 2, 152-156. mai-ago,1999.

BATTIFORA, L.; ADAMA, J. Análise descritiva do manejo de bovinos de corte desde o seu embarque em diferentes províncias do Peru até a chegada e posterior processo nos centros de lucro em Lima. 2000. Disponível em: <http://www.hsi.org/assets/pdfs/manejo_ganado_peru.pdf> Acesso em: 21 ago. 2020.

BERTOLONI, W. et al. Bem-estar e taxa de hematomas de bovinos transportados em diferentes distâncias e modelos de carroceria no estado do Mato Grosso - Brasil. Revista brasileira de saúde e produção animal, v.3, n.3, p.850-859, 2012.

BOIVIN, X. et al. Influence of breed and early management on ease of handling and openfield behaviour of cattle. Applied Animal Behaviour Science, v.32, n.4 p.313-323, 1992. 
BROOM, D.M. The welfare of livestock during transport. In: M. APPLEBY, V. CUSSEN, L. GARCÉS, L. LAMBERT AND J. TURNER (Editors) Long Distance Transport and the Welfare of Farm Animals. Wallingford: CABI, 2008. p.157-181.

BURNS, L.V. Efeito da distância de transporte e condições climáticas sobre os indicadores fisiológicos de bem-estar dos bovinos. 2019. 91f. Tese (Doutorado em Ciência Animal Tropical) - Universidade Federal do Tocantins, Programa de Pós-Graduação em Ciência Animal Tropical, Araguaína, 2019.

CERUTTI, W. G et al. Respostas fisiológicas e produtivas de vacas holandesas em lactação submetidas ou não a sombreamento e aspersão na pré-ordenha. Revista Brasileira de saúde e produção animal, Salvador, v.14, n.3, p.406-412, 2013

CESAR, D.; HUERTAS, S. Bem-estar animal: Boas práticas de embarque e desembarque. $2014 . \quad$ Disponível em:

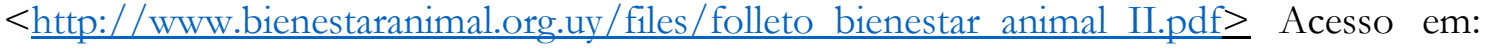
19 ago. 2020.

CHEN, Y. et al. Models and Methods to Investigate Acute Stress Responses in Cattle. Animals, v.5, p.1268-1295,2015

COELHO, A. S.; MAIA, R. B. M.; VIANA, R. B. Abate Humanitário em bovinos. Difusão e comunicação PETVet/Ufra PETVet Radar, v.1, n.5, p. 3, 2017.

COSTA, O. A. D.; LUDKE, J. V.; COSTA, M. J. R. P. Aspectos Econômicos e de Bem Estar Animal no Manejo dos Suínos da Granja até o Abate. IV Seminário Internacional de Aves e Suínos -Avesui, 2005

DUPREEZ, J.H. Parameters for the determination and evaluation of heat stress in dairy cattle in South Africa. Onderstepoort Journal of Veterinary Research, v.67, p.263-271, 2000 .

DEL CAMPO, M. Bem-estar animal como valor agregado nas cadeias produtivas de carne. Capítulo 10 -Bem-estar animal: Sistemas de produção, práticas de manejo e qualidade da carne. Jaboticabal. 2016.

FERREIRA, F. et al. Parâmetros fisiológicos de bovinos cruzados submetidos ao estresse calórico. Arquivo Brasileiro de Medicina Veterinária e Zootecnia, v.58, n.5, p.732-738, 2006.

GALLO, C. et al. Efectos del tiempo de transporte de novillos previo al faenamiento sobre el comportamiento, las pérdidas de peso y algunas características de la canal. Archives Medicina Veterinaria, v.32, p.157-170, 2000.

GOMIDE, L. A. DE. M.; RAMOS, E. M.; FONTES, P. R. Tecnologia de abate e tipificação de carcaças. Viçosa: UFV, p 370, 2006.

GLASER, F.D. Aspectos comportamentais de bovinos da raça angus a pasto frente à disponibilidade de recursos de sombra e água para imersão. Pirassununga, SP: [s.n], 2003. Originalmente apresentada como dissertação de mestrado, USP, 2003 
GRANDIN, T. The feasibility of using vocalization scoring as an indicator of poor welfare during cattle slaughter. Applied Animal Behaviour Science, v.56, n.2-4, p.121128, 1998.

LUDTKE, C. B. et al. Bem-estar animal no manejo pré-abate e a influência na qualidade da carne suína e nos parâmetros fisiológicos do estresse. Ciência Rural, p.532-537, 2012a.

LUDTKE, C.B. et al. Abate humanitário de bovinos. $1^{\text {a }}$ ed. Rio de Janeiro : WSPA, 2012b. $148 \mathrm{p}$.

MOTA, L. S. Adaptação e interação genótipo-ambiente em vacas leiteiras. 1997. 69f. Tese (Doutorado) - Faculdade de Medicina de Ribeirão Preto, Universidade de São Paulo, Ribeirão Preto, SP

NIELSEN, B. L., DYBKJÆR, L.; HERSKIN, M. S. Road transport of farm animals: effects of journey duration on animal welfare. Animal, v.5, n.3, p.415-427, 2011.

OLIVEIRA FILHO, A. Produção e Manejo de Bovinos de Corte. KCM Editora, 2015.

ORGANIZAÇÃO MUNDIAL DA SAÚDE ANIMAL (OIE). Introduction to the recommendations for animal welfare. In:__. Terrestrial Animal Health Code. 2019. Disponível em: <https://www.oie.int/en/standard-setting/terrestrial-code/accessonline/?htmfile=chapitre aw introduction.htm $>$ Acesso em 21 ago. 2020.

PAJOR, E. A.; RUSHEN, J.; DE PASSILÉ, A. M. B. Aversion learning techniques to evaluate dairy cattle handling practices. Applied Animal Behaviour Science, v. 69, p.89102, 2000.

PARANHOS DA COSTA, M.J.R. Ambiência na produção de bovinos de corte. In: ENCONTRO ANUAL DE ETOLOGIA, 18., Florianópolis, Palestras... Florianópolis, Sociedade Brasileira de Etologia, p.1-15. 2000

PARANHOS DA COSTA, M.J.R. . Ambiência e qualidade de carne. In: L.A. Josahkian (ed.) Ambiência e Qualidade da Carne Uberaba, pp. 170-174, 2002.

PEREIRA, A. S. C. Manejo pré abate e qualidade da carne. Programa Carne Angus Certificada,2006. Disponível em: <www.beefpoint.com.br $>$ Acesso em 28 abr. 2020.

POLLI, V.A.; RESTLE, J. Comportamento de bovinos e bubalinos em regime de confinamento - IL hierarquia social. Ciência Rural, Santa Maria, v.25, n.1, p.133-137, 1995.

PIOVEZAN, U. Análise de fatores genéticos e ambientais na reatividade de quatro raças de bovinos de corte ao manejo. 1998, 42f. Dissertação (mestrado) -Faculdade de Ciências Agrárias e Veterinárias do campus de Jaboticabal -UNESP, Campus Jaboticabal, São Paulo, Brasil.

ROBINSON, E.N. Termorregulação. In: CUNNINGHAM, J.G. Tratado de fisiologia veterinária. 2.e1d. Rio de Janeiro: Guanabara Koogan, 1999. cap.51, p.427-435.

ROBERTSHAW, D. Dukes, fisiologia dos animais domésticos: regulação da temperatura e o ambiente térmico. Rio de Janeiro: Guanabara Koogan, 2006. p 899-909 
ROÇA, R. O. Modificações pós-morte da carne, 2001. Disponível em: $<$ http://www.fca.unesp.br/Home/Instituicao/Departamentos/Gestaoetecnologia/Tes es/> Acesso em 14 mai. 2020.

ROSSAROLLA, G. Comportamento de vaca leiteiras da raça holandesa, em pastagem de milheto com e se sombra. 2007. 46f. Dissertação (mestrado em zootecnia) - Centro de Ciências Rurais, Universidade Federal de Santa Maria, 2007

TARRANT, P. V.; GRANDIN, T. Cattle transport. In T. Grandin (Ed.), Livestock handling and transport. Oxford: CAB International. pp. 109-1262000.

TARRANT, P.V.; KENNY, F.J.; HARRINGTON, D. The effect of stocking density during 4 hour transport to slaughter on behaviour, blood constituents and carcass bruising in Friesian steers. Meat Science, v.24, n.3, p.209-222, 1988.

WEBSTER, A.J.F. Meat and Right: Farming as if the Animal Mattered. The Canadian Veterinary Journal v. 28, n.8, p.462-465, 1987. 


\title{
CICLO ESTRAL EM MARRÃS SUÍNAS DE LINHAGEM HIPERPROLÍFICA
}

\author{
Julyanna Cordeiro Maciel
}

Universidade Estadual do Ceará, Faculdade de Veterinária, Fortaleza - Ceará http://lattes.cnpq.br/7544152774489906

\section{Lucas Paz Martins}

Universidade Estadual do Ceará, Faculdade de Veterinária, Fortaleza - Ceará http://lattes.cnpq.br/2982214663044540

\section{Mayra Ferreira Gonçalves}

Universidade Estadual do Ceará, Faculdade de Veterinária, Fortaleza - Ceará http://lattes.cnpq.br/7797463316646856

\section{Atirson Bruno Martins de Sousa}

Universidade Estadual do Ceará, Faculdade de Veterinária, Fortaleza - Ceará http://lattes.cnpq.br/9617806332597532

\section{Caio Vitor Oliveira Silva}

Universidade Estadual do Ceará, Faculdade de Veterinária, Fortaleza - Ceará http://lattes.cnpq.br/9888210306570180

\section{Deborah Marrocos Sampaio Vasconcelos}

Universidade Estadual do Ceará, Faculdade de Veterinária, Fortaleza - Ceará http://lattes.cnpq.br/0963785185263043

\section{Cibelle Mara Pereira de Freitas}

Universidade Estadual do Ceará, Faculdade de Veterinária, Fortaleza - Ceará http://lattes.cnpq.br/5941435633494996

\section{Érica Maria Sousa de Queiroz Campos}

Universidade Estadual do Ceará, Faculdade de Veterinária, Fortaleza - Ceará http://lattes.cnpq.br/6341986339492272

\section{Tiago Silva Andrade}

Universidade Estadual do Ceará, Faculdade de Veterinária, Fortaleza - Ceará http://lattes.cnpq.br/7161796048983496

\section{José Nailton Bezerra Evangelista}

Universidade Estadual do Ceará, Faculdade de Veterinária, Fortaleza - Ceará http://lattes.cnpq.br/3648513271604631

\section{Ênio Campos da Silva}

Universidade Estadual do Ceará, Faculdade de Veterinária, Fortaleza - Ceará http://lattes.cnpq.br/6829076136051055

\section{Lina Raquel Santos Araújo}

Universidade Estadual do Ceará, Faculdade de Veterinária, Fortaleza - Ceará http://lattes.cnpq.br/7591378438576586 
Informações sobre o

artigo:

Recebido em:

$26 / 08 / 2020$

Aceite em:

$31 / 08 / 2020$

Data de publicação:

$05 / 10 / 2020$

Palavras-chave:

Cio

Leitoa

Pro-estro

\section{RESUMO}

Objetivou-se descrever os principais eventos que ocorrem durante os primeiros estros de marrãs suínas de linhagem hiperprolífica. Observou-se o estro de um total de treze marrãs suínas Topigs ${ }^{\circledR}$ com idade aproximada de 154 dias e peso médio de 107,1 kg. As fêmeas foram mantidas em baias coletivas e os sinais de estro observados diariamente, duas vezes ao dia. Foram registrados início e fim das alterações anatômicas relacionadas ao ciclo estral, tais como: edema e hiperemia vulvar, presença de secreção vulvar e de reflexo de tolerância ao macho. O estro durou em média 45,5 horas e o intervalo médio entre cios foi de 20,5 dias e em apenas $31,5 \%$ detectou-se a presença de muco ao cio. Em relação aos três primeiros cios das marrãs não apresentaram diferenças entre si, no entanto, o primeiro cio caracterizou-se por uma curta duração pela presença de muco em $15,4 \%$ das marrãs, já nos demais esse valor variou de 30,8 a $50,0 \%$. O cio de marrãs é mais curto e o pro-estro quase sempre vem acompanhado de edema vulvar. A frequência de cios silenciosos ainda é alta entre as marrãs, e os sinais de estro devem ser valorizados, para que os dias improdutivos não aumentem.

\section{ESTROUS CYCLE IN GILTS OF HYPERPROLIFIC LINEAGE}

\section{ABSTRACT}

The objective was to describe the main events that occur during the oestrus of gilts of hyperprolific lineage. The estrus of a total of thirteen swine gilts Topigs ${ }^{\circledR}$ was observed, with an approximate age of 154 days and an average weight of $107.1 \mathrm{~kg}$. The females were kept in collective pens and the signs of estrus were observed daily, twice a day. The beginning and end of anatomical changes related to the estrous cycle were recorded, such as: edema and vulvar hyperemia, presence of vulvar secretion and reflex of tolerance to the male. Estrus lasted an average of 45.5 hours and the average interval between spans was 20.5 days and in just $31,5 \%$ the presence of mucus in heat was detected. In relation to the first three stages of gilts showed no differences between them, however, the first heat was characterized by a short duration due to the

Keywords:

Oestrus

Pig

Pro-estrus presence of mucus in $15.4 \%$ of gilts, whereas in the others, this value varied from 30.8 to $50.0 \%$. The heat of gilts is shorter and the proestrus is almost always accompanied by vulvar edema. The frequency of silent estrus is still high among gilts, and all signs of heat should be valued, so unproductive days do not increase. 


\section{INTRODUÇÃO}

O Brasil se tornou um grande destaque no mercado suinícola, sendo o $4^{\circ}$ maior produtor e exportador de carne suína do mundo, segundo dados de 2019 da Associação Brasileira de Proteína Animal (ABPA, 2020). As linhagens genéticas atuais têm apresentado altos níveis de prolificidade, o que vem despertando interesse em pesquisadores e produtores quanto ao manejo de marrãs, visto que um fator essencial na eficiência reprodutiva de um plantel suíno é a idade com que as fêmeas são cobertas pela primeira vez (KOKETSU, 2007).

O período em que a marrã de reposição permanece na granja da chegada até a primeira cobertura contribui com aproximadamente 30\% dos dias não produtivos de uma granja (FOXCROFT, 2001). Dessa forma, o período de preparação das marrãs é o que mais contribui com o aumento dos dias não produtivos do sistema de produção de suínos. Portanto uma adequada seleção dessas fêmeas mantém relação direta com a eficiência do processo de produção (BORTOLOZZO et al., 2018).

Atualmente para alcançar o máximo de eficiência produtiva, recomenda-se que as fêmeas suínas sejam cobertas ao $3^{\circ} \mathrm{ou} 4^{\circ}$ cio, com 120 a $140 \mathrm{~kg}$ de peso vivo e entre 230-240 dias de idade. Parâmetros adequados para o início da fase reprodutiva, em que a fêmea estará sexualmente madura e apresentará boa taxa de ovulação com oócitos viáveis para a fertilização (STANIC et al., 2013). Existindo assim, uma correlação positiva entre peso corporal e o total de complexos Cumulus oophorus, conforme o estudo de Neves et al. (2019), por isso é tão importante atender a esses requisitos.

Nesse contexto, a introdução de fêmeas jovens em uma granja organizada por lotes de cobrição causa muitas dúvidas quanto a definição do melhor cio de cobertura, logo há a necessidade de uma programação sistemática e precisa (CARBONE, 2002; FOXCORFT; AHENE, 2000), que pode ser facilmente preparada conhecendo a caracterização do ciclo estral. O objetivo deste trabalho é descrever os principais eventos que ocorrem durante o estro de marrãs.

\section{METODOLOGIA}

O experimento foi conduzido nas instalações da unidade experimental do Setor de Suínos da Faculdade de Veterinária da Universidade Estadual do Ceará. Foram observadas 
13 fêmeas híbridas F1 Landrace (L) x Large White (Z), da linhagem TN70 da Topigs Norsvin ${ }^{\circledR}$.

As marrãs foram adquiridas entre os meses de março e maio de 2018, com idade aproximada de 154 dias e peso médio de 107,1 kg. Ao chegar, passaram por um período adaptativo de 15 dias, onde nenhum tipo de manejo, além de arraçoamento, foi realizado.

As fêmeas tinham acesso à vontade à água em bebedouros do tipo chupeta e o arraçoamento era feito uma vez ao dia manualmente. Durante o período próprio de observação, foram fornecidos $2,5 \mathrm{~kg}$ de ração do tipo reposição a cada um dos animais até que atingissem aproximadamente 238 dias de idade (Figura 1). Logo em seguida, passaram por um período de flushing (15 dias), em que receberam 2,5 kg de ração do tipo lactação e por fim, foram inseminadas mantidas as condições de manejo empregadas normalmente na unidade, que consta no fornecimento de $2 \mathrm{~kg}$ de ração do tipo reprodução.

Figura 1. Fase de preparação de marrãs e perfil de arraçoamento até o início da vida reprodutiva evidenciando o período de observação dos sinais de cio.

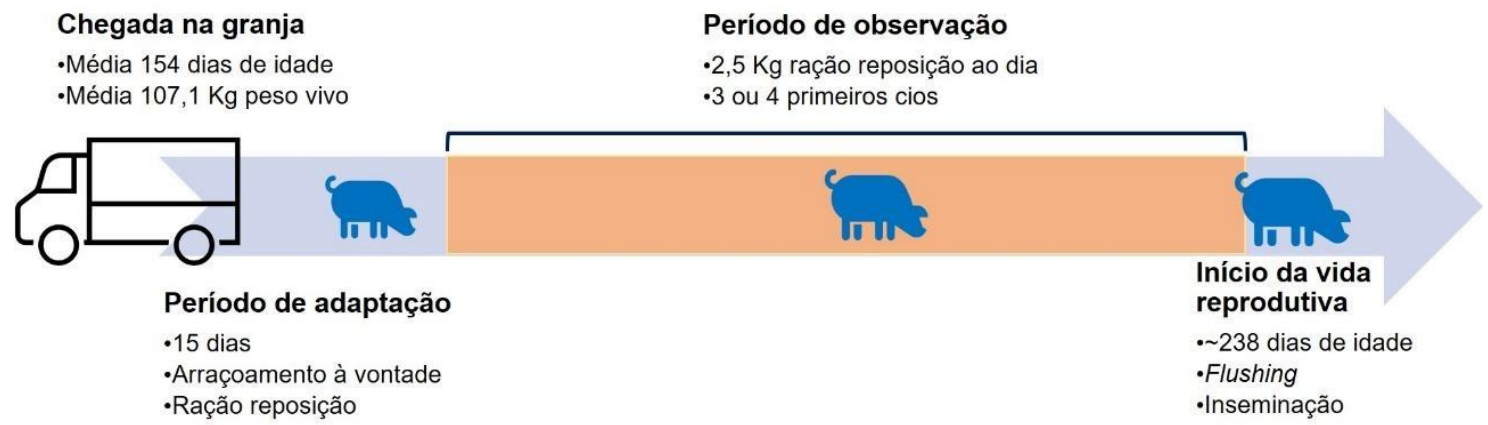

Fonte: Elaborada pelos autores

Todas as marrãs estudadas foram agrupadas em baias coletivas com 2 a 3 marrãs cada, tendo manifestado sintomas de estro em pelo menos uma oportunidade (Figura 2). Durante quatro períodos de estro consecutivos, nenhuma das marrãs foi inseminada natural e ou artificialmente, perfazendo em média 143 dias de observação. 
Figura 2. Marrãs alojadas em baias coletivas com comedouro de alvenaria e paredes vazadas permitindo contato visual com outras marrãs.

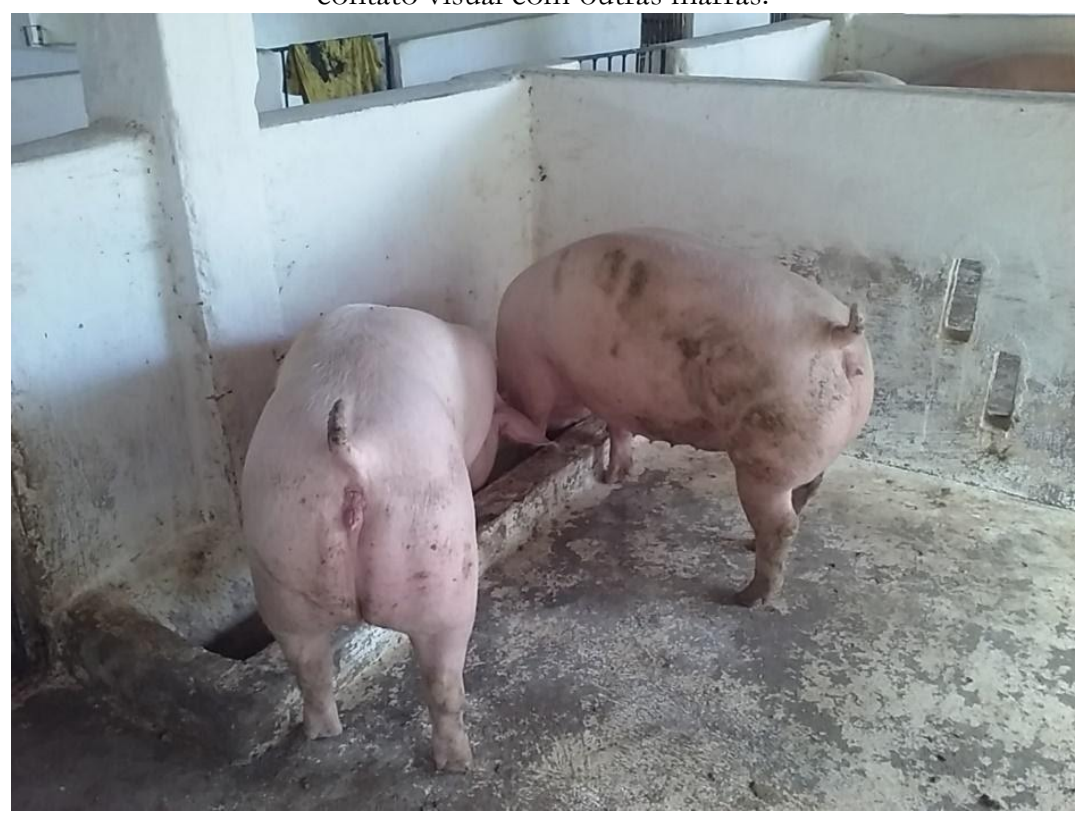

Fonte: Acervo próprio.

No período experimental, os sinais estrais foram observados diariamente sempre no mesmo horário, às 07:00 e às 17:00. Nos dias que antecederam a data prevista do estro, eram levadas ao cachaço maduro. Sendo registrados parâmetros estrais (Figura 3) como edema e hiperemia de vulva, presença de muco vaginal e reflexo de tolerância ao macho (RTM). Para calcular os intervalos, registrou-se a data de início dos sinais e adotou-se como data final do evento avaliado (estro ou edema de vulva) o próximo horário em que o evento não estava mais presente. Os dados observados foram compilados em planilha Excel ${ }^{\circledR}$ e submetidos a análise de variância (ANOVA) e as médias das variáveis de cada ciclo estral foram comparadas pelo teste de Tukey a 5\% utilizando o Programa Estatístico R. Para comparação do percentual de fêmeas que apresentaram secreção vulvar utilizou-se o Teste do Qui-quadrado.

Figura 3. Identificação de parâmetros estrais em marrãs frente ao macho.

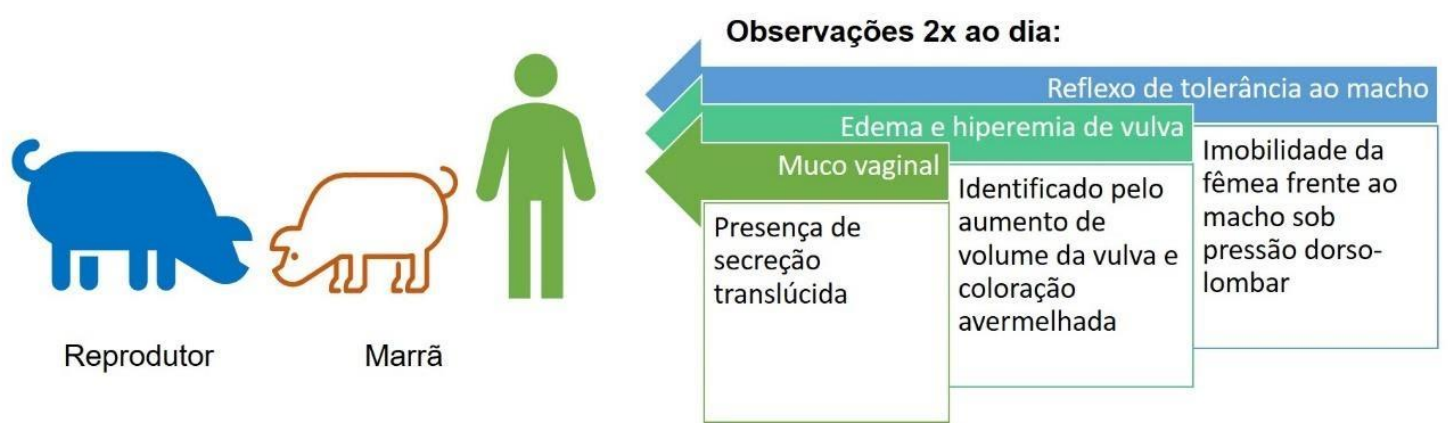

Fonte: Elaborada pelos autores 


\section{RESULTADOS E DISCUSSÃO}

$\mathrm{Na}$ tabela 1 estão apresentados os parâmetros do ciclo estral das marrãs nos primeiros cios após a chegada na granja. Os sinais indicativos do pro-estro, como o edema de vulva, foi observado em 90,6\% dos estros, com duração média de 2,4 dias. Além disso, em apenas duas fêmeas foi observado o ato de montar sobre outras ou sobre as divisórias da baia e a presença de muco foi registrada em apenas $31,5 \%$ dos cios observados.

Tabela 1. Parâmetros do ciclo estral de marrãs ao $1^{\circ}, 2^{\circ}, 3^{\circ}$ e a partir do $4^{\circ}$ cio.

\begin{tabular}{lccccc}
\hline & $\begin{array}{c}\text { Idade ao } \\
\text { cio }\end{array}$ & $\begin{array}{c}\text { Duração do edema } \\
\text { vulva (dias) }\end{array}$ & $\begin{array}{c}\text { Presença de muco } \\
(\%)\end{array}$ & $\begin{array}{c}\text { Duração do cio } \\
\text { (horas) }\end{array}$ & $\begin{array}{c}\text { Intervalo entre estros } \\
\text { (dias) }\end{array}$ \\
\hline $1^{\circ}$ cio & 184,5 & 2,0 & 15,4 & 40,3 & 19,6 \\
$2^{\circ}$ cio & 201,2 & 2,2 & 30,8 & 53,6 & 21,0 \\
$3^{\circ}$ cio & 229,1 & 2,4 & 50,0 & 48,0 & 21,3 \\
$>4^{\circ}$ cio & 255,4 & 2,5 & 31,3 & 43,2 & 19,9 \\
\hline Média & & 2,4 & 31,5 & 45,5 & 20,5 \\
DP & 0,6 & - & 12,6 & 2,5 \\
CV (\%) & 27,1 & - & 26,5 & 12,1 \\
Valor de & 0,321 & 0,324 & 0,967 & 0,781 \\
P & & & & &
\end{tabular}

DP: desvio padrão; CV: coeficiente de variação. Médias não diferiram pelo Qui-quadrado e Teste de Tukey.

A duração do edema de vulva não diferiu entre os ciclo estrais observados $(\mathrm{P}>0,05)$, apresentou em média 2,4 dias, correspondendo ao período de pró-estro que, de acordo com a literatura consultada, possui duração de 1 a 3 dias (BORTOLOZZO et al., 2007). O primeiro estro foi detectado aos 184,5 dias acompanhado de uma menor frequência de secreção vulvar (muco). Com o aumento da idade, a presença de muco durante o cio tornouse mais frequente. Esse resultado sugere que com o passar dos cios, a fêmea além de mais velha e com maior peso vivo, está também mais madura sexualmente, evidenciando de maneira mais clara os sinais estrais. Estas observações corroboram com Britt (1998), que relata que o primeiro estro da marrã ocorre entre o 6 e 7 mês de idade, estando associado à maturação do eixo hipotálamo-hipófise que é fortemente influenciado pela genética, idade, peso corporal, estado metabólico, estação do ano, temperatura, sociabilidade, exposição ao macho, manejo e outros (HUGHES, 1982). Quanto aos primeiros ciclos das marrãs, podese observar que não houve diferenças quanto a duração dos mesmos $(\mathrm{P}<0,05)$, embora o intervalo entre o $1^{\circ}$ e $2^{\circ}$ tenha apresentado menor duração que os demais. 
A detecção de cio sempre gera dúvidas entre os iniciantes na suinocultura, por vezes o edema e a hiperemia vulvar podem ser confundidos com sinais de que a fêmea está em cio, por representarem os sinais mais prevalentes no estro de marrãs (BORTOLOZZO et al., 2006). No entanto, o edema e hiperemia vulvar (Figura 4A) não definem o início do estro, correspondem a alterações anatômicas relacionadas aos elevados níveis de estrógeno que ocorrem no pro-estro (BORTOLOZZO et al., 2007). Tais alterações podem vir acompanhadas de alterações comportamentais como o ato das fêmeas saltarem sobre outras (Figura 5) ou de se interessarem pelo macho (Figura 6).

Por outro lado, o estro se inicia quando a marrã apresenta reflexo de imobilização ou reflexo de tolerância ao macho, que também pode ser visualizado na Figura 5, na fêmea que se deixa ser montada. As alterações anatômicas (Figura 4B), como edema e hiperemia vulvar, tornam-se menos intensas nesta fase, extinguindo-se totalmente nas fases de metaestro e diestro (Figura 4C), que duram em média 2-3 dias e 7 a 10 dias respectivamente (BORTOLOZZO et al., 2007). Neste estudo a duração do cio das marrãs variou de 34 a 72 horas. É sabido que a duração do cio das marrãs é mais curta que em porcas, e que o cio detectado com o auxílio do cachaço apresenta uma maior duração quando comparada àquela na ausência do macho (ZANELLA, 2003).

Figura 4. Vista posterior de marrã mostrando diferenças anatômicas na vulva em diferentes fases do ciclo estral.
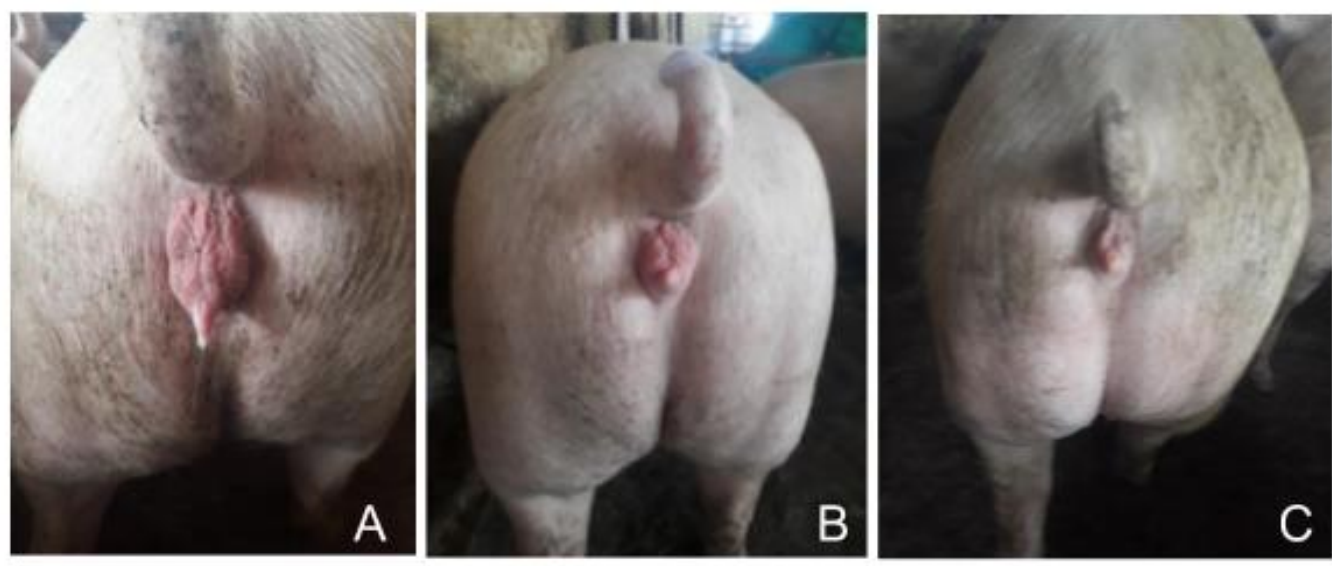

(A) Marrã em pro-estro apresentando edema, hiperemia e secreção vulvar; (B) Marrã no estro apresentando edema e hiperemia vulvar menos intensa; (C) Marrã após o período de estro apresentando vulva com tamanho e coloração normal. Fonte: Acervo próprio. 
Figura 5. Marrã em pro-estro apresentando comportamento de saltar sobre outras fêmeas e marrã em estro

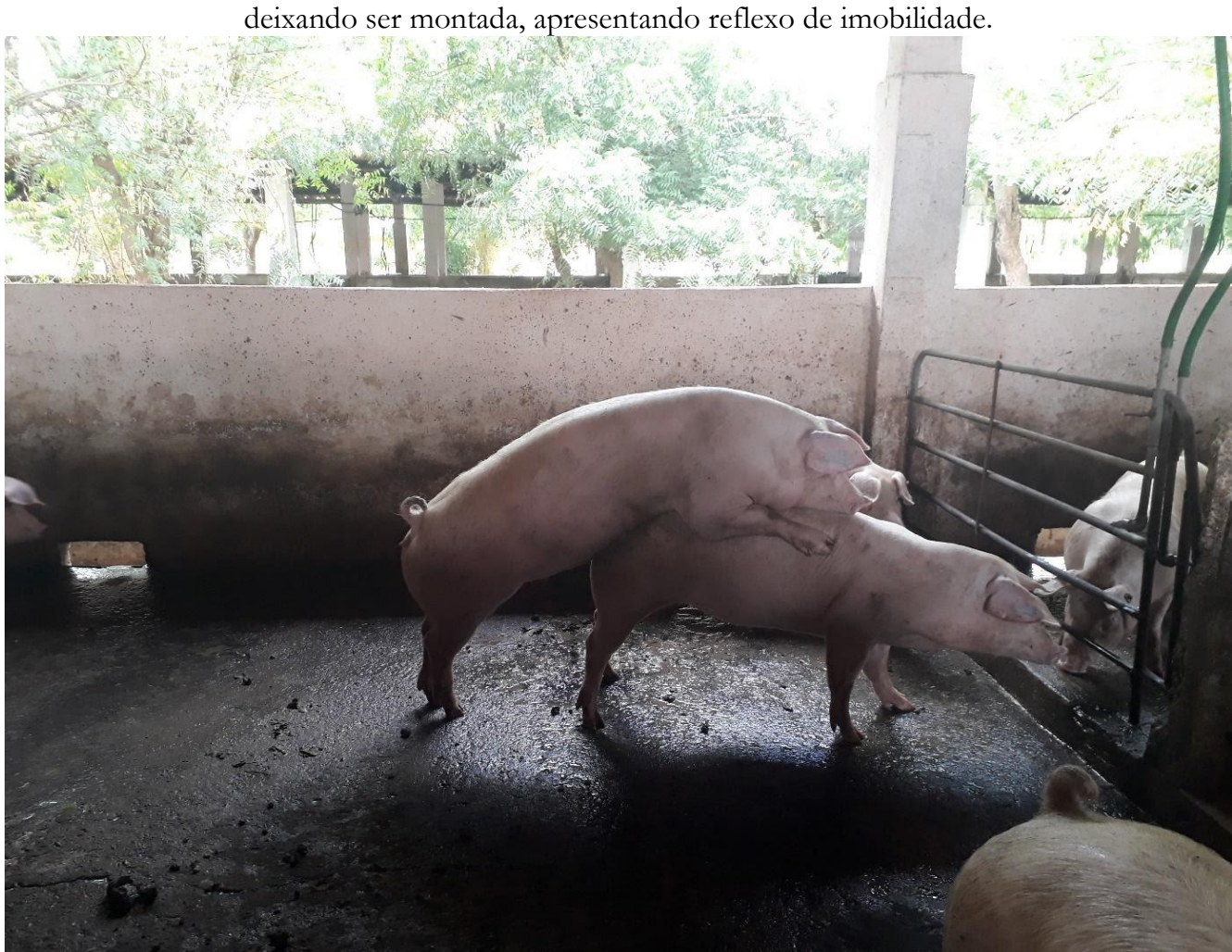

Fonte: Acervo próprio.

Figura 6. Marrã em pro-estro apresentando interesse pelo macho, saltando sobre a mureta.

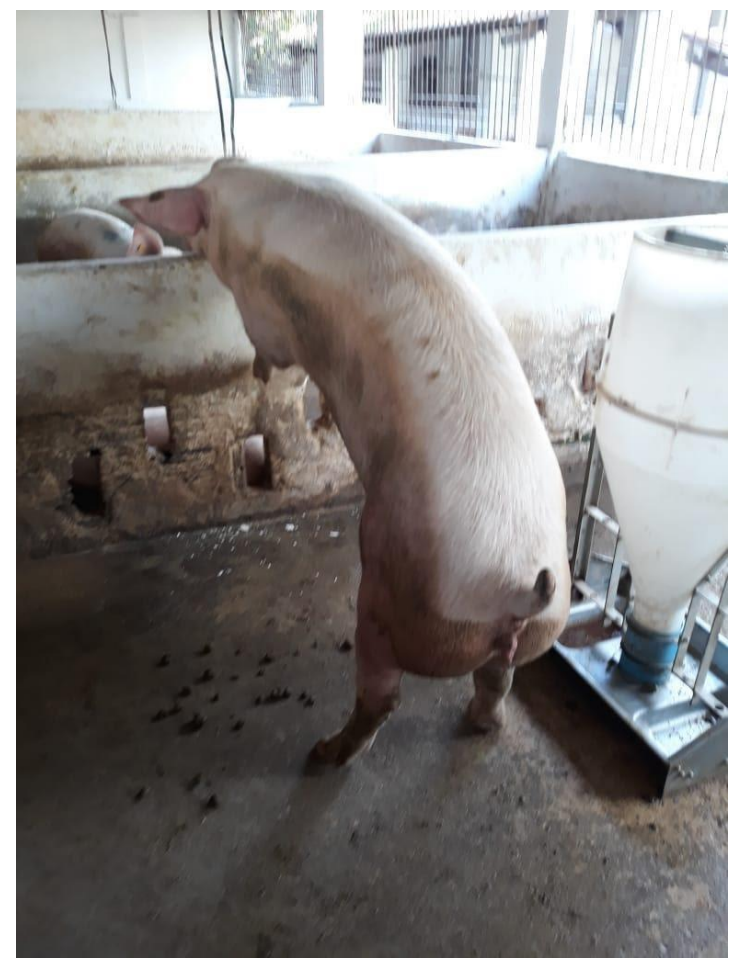

Fonte: Acervo próprio. 
Segundo Frare et al. (2013) a duração do estro em leitoas dura em média 26 a 36 horas e segundo Bortolozzo et al. (2007) a duração média do estro em fêmeas suínas é de 50 a 80 horas, corroborando com este estudo, em que o cio em marrãs detectado na presença do cachaço apresentou duração média de 45,5 horas. As marrãs observadas apresentaram intervalo entre ciclos próximo ao que é amplamente divulgado na literatura, 21 dias (CONNOR, 1989; ANDERSON, 2000). O intervalo entre estros, ou seja, a duração do ciclo estral, é um dado importante no manejo de fêmeas de reposição. Dada a ciclicidade e a regularidade do cio das marrãs o intervalo entre estros é utilizado para programar manejos como detecção de cio, flushing, vacinação e primeira inseminação. No entanto, o criador ainda pode enfrentar dificuldades nessa prática de manejo, pois algumas marrãs podem apresentar cio silencioso.

Geralmente fêmeas jovens (leitoas e primíparas) apresentam maiores incidências de cio silencioso (SILVEIRA; WENTZ; BARROS, 1985; SILVEIRA; WENTZ, 1986). Dos ciclos estrais observados, em 13,2\% as fêmeas apresentavam sinais de cio, como edema de vulva ou presença de muco, entretanto, não apresentavam o reflexo de tolerância ao macho, tampouco ao homem, prejudicando a determinação real do início de cio. Segundo Paterson (1982), leitoas jovens podem apresentar edema de vulva sem estro ou ovulação após o manejo com o macho, nessas fêmeas o crescimento folicular é interrompido não alcançando a ovulação, provavelmente devido ao um déficit no feedback positivo do estradiol na secreção de LH. Neste sentido a idade com a qual as fêmeas recebem os primeiros estímulos é importante para o efeito macho, para tanto recomenda-se que o contato com o macho se inicie entre 150 e 170 dias de idade, conforme adotado neste estudo (BORTOLOZZO et al., 2006).

\section{CONSIDERAÇÕES FINAIS}

O cio de marrãs é mais curto e o pro-estro quase sempre vem acompanhado de edema vulvar, sendo observadas diferenças sutis entre os cios subsequentes. A frequência de cios silenciosos ainda é elevada entre marrãs, devendo ser valorizado os sinais de cio, para que não ocorra o aumento de dias não produtivos. 


\section{REFERÊNCIAS}

ANDERSON, L. L. Pigs. In: HAFEZ, B.; HAFEZ, E.S.E. (Eds.), Reproduction in farm animals. 7 ed. Philadelphia: Lippincott Williams \& Wilkins. 2000. pp. 182-191.

ASSOCIAÇÃO BRASILEIRA DE PROTEÍNA ANIMAL, ABPA. Relatório Anual de atividades 2020. ABPA, 2020. Disponível em: <http://abpa-br.org/relatorios/>Acesso em: 02 ago.2020.

BORTOLOZZO, F.P.; WENTZ, I.; BERNARDI, M.L.; MELLAGI, A.P.G.; AMARAL FILHA, W.S.; PANZARDI, A.; VARGAS, A.J.; KUMMER, R.; WILLIAMS, N. Suinocultura em ação 4: A fêmea suína gestante. Porto Alegre: Gráfica da UFRGS, 2007. $150 \mathrm{p}$.

BORTOLOZZO, F.P.; WENTZ, I.; BERNARDI, M.L.; KUMMER, R.; AMARAL FILHA, W.S.; MELLAGI, A.P.G.; FURTADO, C.S.D. Suinocultura em ação 4: A fêmea suína de reposição. Porto Alegre: Gráfica da UFRGS, 2006. 128p.

BORTOLOZZO FP, OLIVEIRA G, WALTER MP, MELLAGI APG, ULGUIM RR. Leitoas com baixo ganho de peso diário na seleção tem comprometimento reprodutivo subsequente? In: Anais do XI Simpósio Internacional de Suinocultura, Porto Alegre, Rio Grande do Sul, p.107-122, 2018.

BRITT, J.H. Manipulation of the porcine estrous cycle. In: Controlled breeding en gilts and sows improving reproduction and litter size in sows. In: MEMORIAIS CONGRESSO AMVEC’98, 1998, León, Guanajuato. Proceedings... Guanajuato: AMVEC, 1998.

CARBONE, A. Emprego de gonadotrofinas exógenas na indução e sincronização da puberdade em marrãs. 2002. 60 f. Dissertação (Mestrado em Reprodução Animal) Faculdade de Medicina Veterinária e Zootecnia, Universidade de São Paulo, 2002. Disponível em: https://repositorio.usp.br/item/001234258

CONNOR J.F. Reproductive problems in swine breeding herds: making the field diagnosis. Food Animal Practice. v.5, p.318-327, 1989.

FOXCORFT, G.; AHERNE, F. Manejo de marrã de reposição e da porca de de primeiro parto: Parte II. Selecionando marrãs para uma melhor vida reprodutiva. In: VII Simpósio Internacional de Reprodução e Inseminação Artificial em Suínos, 2000, Foz do Iguaçu. Anais... Foz do Iguaçu, 2000, p.91-98.

FOXCROFT GR. Técnicas de indução da puberdade e sincronização para atingir as metas de cobrição do lote de leitoas de reposição. In: Anais do Congresso Latino Americano de Suinocultura I, Foz do Iguaçu, Paraná, p.3-13, 2001.

FRARE, A. L.; PONTILI, A. D.; BINI, D.; JACOBOVSKI, D. A.; TEIXEIRA, E.; MALHERBI, G.; MEIRELlES, C. Ciclo Estral em Suínos. Faculdade Assis Gurgacz, Cascavel, 2013. $\quad$ p. 2013.2 Disponível em: https://www.academia.edu/8068571/CICLO_ESTRAL_EM_SUINOS 
HUGES, P.E. Factors affecting the natural attainment of puberty in the gilt. In: COLE, D. J. A.; FOXCROFT, G.R. (Ed.) Control of pig reproduction. London: Butterwoths, 1982, p. 117-138.

KOKETSU, Y. Longevity and efficiency associated with age structures of female pigs and herd management in commercial breeding herds. Journal of Animal Science, v.85, p.10861091, 2007.

NEVES, A.C.; MARCONDES, G., SILVA, I.C.; LODDI, M.M.; KAROLEWSK, L.S.L. Avaliação morfométrica ovariana e recuperação de complexos Cumulus oophorus de fêmeas suínas pré-púberes por aspiração folicular e secção dos ovários. Archives of Veterinary Science v.24, n.3, p.12-21, 2019.

PATERSON, A.M. The controlled induction of puberty. In: COLE, D.J.A.; FOXCROFT, G.R. Control of Pig Reproduction. cap 7, p. 139-159. 1982.

SILVEIRA, P. R. S.; WENTZ, I. Anestro e cio silencioso em porcas desmamadas. Comunicado técnico EMBRAPA-CNPSA, v. 104, p. 1-2, 1986.

SILVEIRA, P. R. S.; WENTZ, I.; BARROS, S. S. Leitoas que não entram em cio: observações do trato genital após o descarte. Comunicado técnico EMBRAPACNPSA, n. 88, p. 1-2, 1985.

STANIC, P., HLAVATI, V., GELO, N., BALDANI, D.P., GOLDŠTAJN, M.Š., RADAKOVIĆ, B., KASUM, M., STRELEC, M., ŠIMUNIĆ, V., VRČIĆ, H. Vitrified oocytes and embryos: contribution to cumulative pregancy rate in an infertility program where only a limited number of oocytes be inseminated per cycle. 2013. Disponível em: https://www.bib.irb.hr/634191

ZANELLA, E. L.; SILVEIRA, P. R. S. da; ALVARENGA, M. V. F.; VIANNA, W. L; GRIEDER, W; BARIONI JÚNIOR, W. A sincronização do cio em leitoas sexualmente maduras utilizando regumate. In: Congresso Brasileiro de Veterinários Especialistas em Suínos, 11., 2003. Goiânia. Anais... Goiânia, ABRAVES, 2003, p. 167 


\section{Dirofilaria immitis EM CÃES: REVISÃO DE LITERATURA}

\section{Letícia Soares Holanda}

Centro Universitário Maurício de Nassau (UNINASSAU), Centro de Saúde, Fortaleza - Ceará http://lattes.cnpq.br/1931616014306144

https://orcid.org/0000-0002-9411-6885

\section{Camila Castelo Trajano}

Universidade de Fortaleza (UNIFOR), Centro de Saúde, Fortaleza - Ceará

http://lattes.cnpq.br/2663658854443435

https://orcid.org/0000-0002-1967-7842

\section{Máyra Carvalho Petelinkar}

Universidade de Fortaleza (UNIFOR), Centro de Saúde, Fortaleza - Ceará

http://lattes.cnpq.br/5981111350891482

https://orcid.org/0000-0002-7499-4226

\section{Francisco Humberto Marques Sampaio Júnior}

Universidade Estadual do Ceará (UECE), Faculdade de Veterinária, Fortaleza - Ceará

http://lattes.cnpq.br/9353106029410768

https://orcid.org/0000-0002-8939-2869

\section{José Ryan Ribeiro Tavares}

Centro Universitário Maurício de Nassau (UNINASSAU), Centro de Saúde, Fortaleza - Ceará http://lattes.cnpq.br/8956703680664291

https://orcid.org/0000-0002-4293-4739

\section{Julia Carrah Colares}

Universidade Estadual do Ceará (UECE), Faculdade de Veterinária, Fortaleza - Ceará

http://lattes.cnpq.br/4433314772251051

https://orcid.org/0000-0001-6056-763X

\section{Victor Hugo Vieira Rodrigues}

Centro Universitário Maurício de Nassau (UNINASSAU), Centro de Saúde, Fortaleza - Ceará http://lattes.cnpq.br/2226604565550002

https://orcid.org/0000-0003-2974-8015

Informações sobre o

artigo:

Recebido em:

28/08/2020

Aceite em:

$31 / 08 / 2020$

Data de publicação:

$05 / 10 / 2020$

\section{RESUMO}

A dirofilariose é uma doença causada por vermes do gênero Dirofilaria, sendo a espécie mais relevante a Dirofilaria immitis. Objetivou-se neste trabalho realizar uma revisão literária a respeito da dirofilariose canina, devido à sua importância na clínica médica, diagnóstica e epidemiológica em pequenos animais. A transmissão ocorre através da picada dos mosquitos dos gêneros Cullex, Aedes e Anopheles, por liberarem larvas que alcançam a circulação sanguínea do hospedeiro definitivo. Quando adultos, os vermes acometem a artéria pulmonar e o coração. Os principais sinais clínicos observados em cães são: dispneia, tosse, convulsões, diarreia, vômitos, letargia, taquicardia, anorexia, síncope e morte súbita. O diagnóstico da doença é através do Ensaio de 


\begin{tabular}{|c|c|}
\hline $\begin{array}{l}\text { Palavras-chave: } \\
\text { Dirofilariose } \\
\text { Parasito } \\
\text { Pequenos animais }\end{array}$ & $\begin{array}{l}\text { Imunoabsorção Enzimática (ELISA), ecocardiograma, } \\
\text { eletrocardiograma e raio-X, e o tratamento, de acordo com a } \\
\text { Sociedade Americana de Dirofilariose, é realizado administrando- } \\
\text { se Melarsomina e Prednisona. Desta forma, é importante ter o } \\
\text { conhecimento sobre as características da dirofilariose, bem como } \\
\text { seus aspectos epidemiológicos e o emprego de diagnósticos para } \\
\text { que seja estabelecido um tratamento eficaz e, consequentemente, } \\
\text { promover o bem-estar do animal. }\end{array}$ \\
\hline $\begin{array}{l}\text { Keywords: } \\
\text { Dirofilariasis } \\
\text { Parasite } \\
\text { Small animals }\end{array}$ & $\begin{array}{l}\text { DIROFILARIA IMMITIS IN DOGS: LITERATURE } \\
\text { REVIEW } \\
\text { ABSTRACT } \\
\text { Dirofilariasis is caused by worms of the genus Dirofilaria, the most } \\
\text { relevant species being Dirofilaria immitis. This paper aims to } \\
\text { perform a literature review on canine heartworm, given its } \\
\text { importance in the clinic, diagnostic and epidemiology of small } \\
\text { animals. Transmission occurs through the bite of mosquitoes of } \\
\text { the genera Cullex, Aedes and Anopheles, that inoculates larvae in the } \\
\text { blood circulation of the definitive host. As adults, the worms infect } \\
\text { the pulmonary artery and the heart. The main clinical signs } \\
\text { observed in dogs are: dyspnea, cough, convulsions, diarrhea, } \\
\text { vomiting, lethargy, tachycardia, anorexia, syncope and sudden } \\
\text { death. The diagnosis is obtained through Enzyme-linked } \\
\text { Immunosorbent Assay (ELISA), echocardiogram, microfilaria } \\
\text { tests, electrocardiogram and radiography, and the treatment, } \\
\text { according to the American Heartworm Society, is accomplished by } \\
\text { administering Melarsomine and Prednisone. Therefore, it is } \\
\text { important to have knowledge about the characteristics of } \\
\text { dirofilariasis, as well as its epidemiological aspects and diagnostics } \\
\text { in order to establish an effective treatment and, consequently, } \\
\text { promote the animal's well-being. }\end{array}$ \\
\hline
\end{tabular}

\section{INTRODUÇÃO}

A dirofilariose é uma parasitose causada por nematoides do gênero Dirofilaria, sendo uma das espécies mais relevantes a Dirofilaria immitis, a qual é responsável por alterações no hospedeiro definitivo, como em cães, gatos e, raramente, humanos. Possui uma relação simbiótica com a bactéria Wolbachia pipientis que lhe confere patogenicidade através da interação com o sistema imunitário do hospedeiro definitivo (SILVEIRA, 2018), ocorrendo com maior prevalência em regiões litorâneas tropicais e subtropicais no Brasil, pois o ambiente é propício para o desenvolvimento desses vetores (DELLING, 2019).

A transmissão ocorre através do repasto sanguíneo realizada pelos culicídeos dos gêneros Cullex, Aedes e Anopheles que liberam larvas as quais se deslocam através dos tecidos 
até alcançarem algum vaso sanguíneo para serem transportadas aos pulmões e ao coração. Os vermes quando adultos alcançam a artéria pulmonar, ocasionando um processo de inflamação na parede dos vasos pulmonares, resultando em resistência vascular ou hipertensão pulmonar. Estes, também, se alojam no coração, podendo ocorrer hipertrofia do lado direito do coração (FREITAS, 2017).

Um dos principais sinais clínicos que podem ser observados em cães são: dispneia, tosse e letargia. Para avaliar o caso de uma forma mais segura, recomenda-se realizar o diagnóstico desta enfermidade através do Ensaio de Imunoabsorção Enzimática (ELISA) que apresenta uma alta sensibilidade para a Dirofilaria immitis (SILVEIRA, 2018).

Devido à importância dessa doença na rotina clínica médica de pequenos animais, objetivou-se em realizar uma revisão bibliográfica sobre a dirofilariose canina, apresentando os aspectos morfológicos da Dirofilaria immitis, bem como o ciclo de vida, os vetores biológicos, a epidemiologia, a patogenia e o diagnóstico para elucidar estas características no emprego de um tratamento eficaz.

\section{DESENVOLVIMENTO}

\subsection{Classificação sistemática}

De acordo com Silveira (2018), o gênero Dirofilaria é dividido no subgênero Dirofilaria, que tem como espécie a Dirofilaria immitis, e no subgênero Nochtiella, que tem como espécies a Dirofilaria repens, a Dirofilaria tenuis e a Dirofilaria ursi.

O parasito Dirofilaria immitis pertence ao filo Nematelmintes, à classe Sercenentea, à subclasse Filaruidea, família Filariidae, gênero Dirofilaria e espécie Dirofilaria immitis (FREITAS, 2017).

\subsection{Morfologia}

Morfologicamente, as microfilárias, fase larvária da Dirofilaria immitis, na circulação sanguínea, medem aproximadamente 285 a $325 \mu \mathrm{m}$ de comprimento e 5,0 a 7,5 $\mu \mathrm{m}$ de diâmetro (DELLING, 2019). Além disso, possuem extremidade cefálica afiliada e extremidade caudal estendida. (CICARINO, 2009). 
$\mathrm{Na}$ fase adulta, esse parasito é um verme que apresenta o corpo filiforme, longo e com a extremidade anterior arredondada. (CICARINO, 2009). Também possui cor cinza esbranquiçada, com uma camada transparente revestindo-o. Ele mede aproximadamente de 15 a $30 \mathrm{~cm}$ nessa fase, sendo as fêmeas medindo o dobro de comprimento dos machos (FREITAS, 2017; DELLING, 2019). Os machos, por sua vez, possuem a cauda em formato espiral, ao contrário das fêmeas que possuem a cauda arredondada (CICARINO, 2009). Essa diferença entre os sexos do parasito pode ser observada na Figura 1.

Figura 1. Dirofilaria immitis fêmea (superior) e macho (inferior). Fonte: Pacheco (2016).

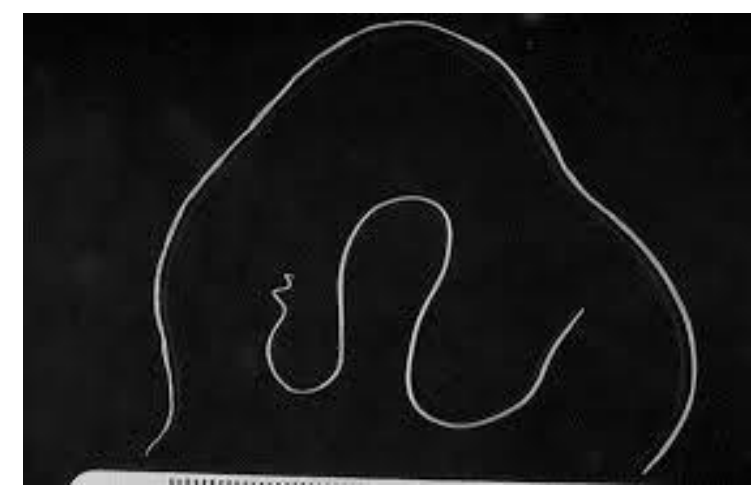

\subsection{Ciclo de vida}

O ciclo de vida do verme Dirofilaria immitis é heteroxeno, ou seja, o parasito possui mais de um hospedeiro, no caso um hospedeiro intermediário obrigatório e um hospedeiro definitivo. O hospedeiro intermediário obrigatório nesse ciclo é um artrópode picador da família Culicidae. As larvas de Dirofilaria apresentam uma baixa especificidade em relação ao seu hospedeiro definitivo, afetando inúmeras espécies, especialmente os canídeos domésticos (Canis familiaris) e os canídeos selvagens, tais como os lobos (Canis lupus), as raposas vermelhas (Vulpes vulpes) e os chacais (Canis aureus) (MEIRELES, 2014; SILVEIRA, 2018).

Esse parasito possui um ciclo de vida dividido em cinco estágios larvais, os três primeiros ocorrem no hospedeiro intermediário obrigatório invertebrado e os dois últimos em um hospedeiro definitivo vertebrado (ALHO et al., 2014). Os hospedeiros definitivos, apesar de serem principalmente canídeos domésticos, podem vir a ser felídeos e humanos, e, assim como os outros hospedeiros definitivos, funcionam como reservatórios da doença, infectando os mosquitos vetores (SILVEIRA, 2018; TRANCOSO, 2020).

A transmissão ocorre através de mosquitos dos gêneros Culex, Aedes e Anopheles que transportam a larva infectante (larvas do terceiro estágio de desenvolvimento), atuando, 
portanto, como vetores biológicos. O mosquito do sexo feminino se infecta ao alimentar-se do sangue de um hospedeiro definitivo que apresente microfilárias (larvas no primeiro estágio de desenvolvimento, larva 1 ou L1) em sua circulação sanguínea (MEIRELES, 2014). No organismo do mosquito, as microfilárias atingem os túbulos de Malpighi após cerca de 24 horas e lá se desenvolvem, passando para o segundo estágio de desenvolvimento, larva 2 ou L2 cerca de nove dias depois. Por fim, as larvas sofrem mudança novamente após três dias, passando para o terceiro estágio de desenvolvimento, larva 3 ou L3, assumindo a forma infectante. As L3 migram para o aparelho bucal do inseto, onde permanecem até a próxima refeição deste, quando penetram nos tecidos do hospedeiro definitivo por meio da solução de continuidade provocada pela picada (MEIRELES, 2014; SILVEIRA, 2018).

No organismo do hospedeiro definitivo, as larvas vão para o quarto estágio de desenvolvimento, larva 4 ou L4 por volta de seis a 10 dias após a infecção. Após a metamorfose, as L4 migram do tecido muscular e do tecido subcutâneo para a cavidade abdominal e a cavidade torácica. Por fim, após 40 a 60 dias, as larvas mudam para o quinto estágio desenvolvimento, larva 5 ou L5, o último estágio larval, e penetram nas veias, indo até o coração, motivo pelo qual são comumente chamadas "verme do coração" ou, em inglês, “beartworm” (SILVEIRA, 2018).

As larvas atingem maturidade sexual por volta dos 120 dias após a infecção, localizadas na artéria pulmonar e no ventrículo direito. Quando as larvas L5 chegam aos pulmões, estas são forçados pela pressão sanguínea na direção de pequenas artérias pulmonares e, conforme o tamanho de Dirofilaria immitis aumenta, posteriormente vão para as artérias de maiores dimensões (MEIRELES, 2014). Entre seis a nove meses após a infecção, as fêmeas iniciam a liberação de microfilárias. A vida dos adultos dura cerca de sete anos, enquanto as das microfilárias duram cerca de dois anos (MEIRELES, 2014; SILVEIRA, 2018). Esse ciclo biológico está ilustrado na Figura 2. 
Figura 2. Ciclo de vida da Dirofilaria immitis. Fonte: Adaptado de CICARINO (2009).

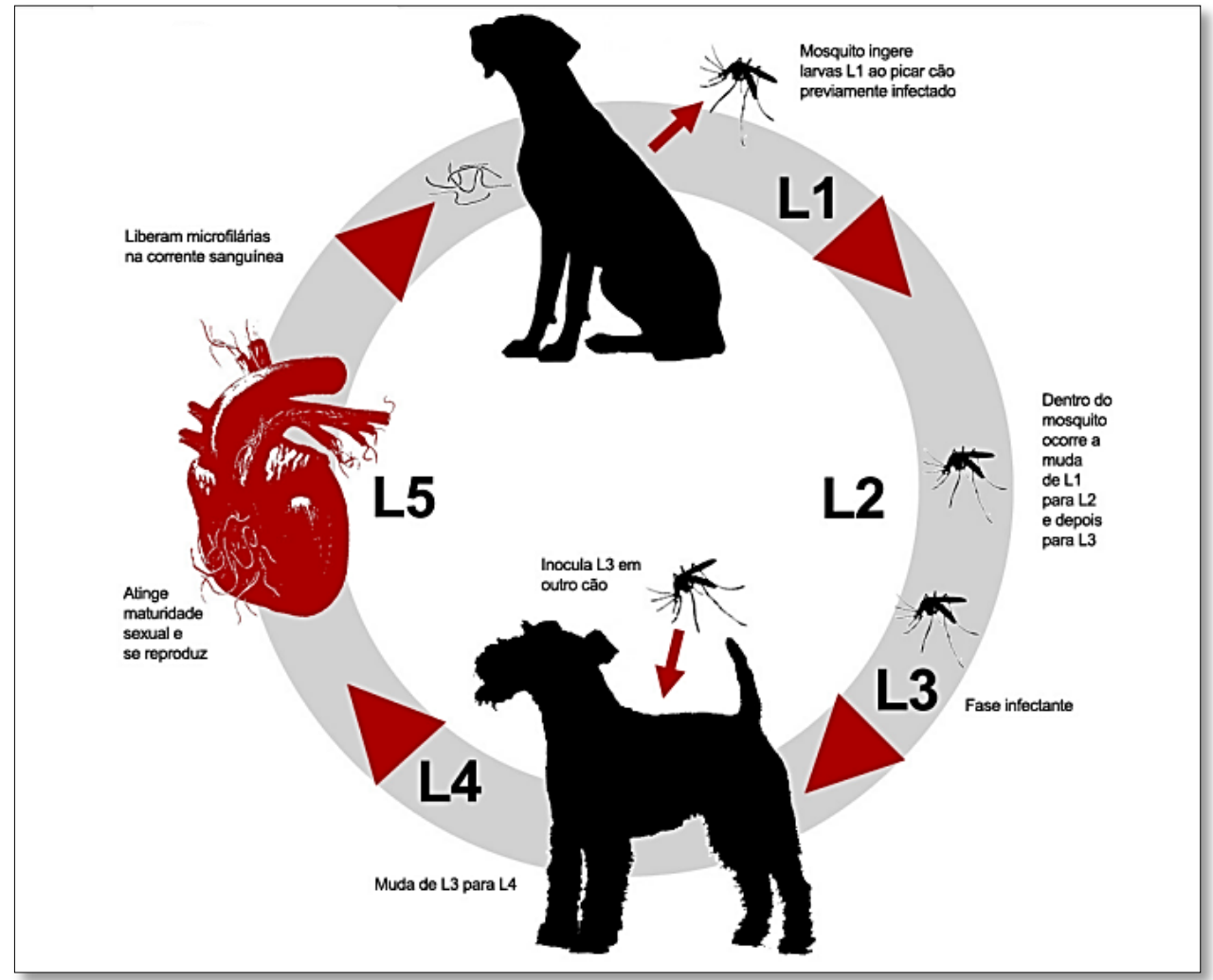

\subsection{Vetores biológicos}

A transmissão da Dirofilaria immitis é realizada por culicídeos pertencentes à ordem Diptera, família Culicinae e subfamílias Culicinae e Anophelinae. Destas, os gêneros que normalmente realizam o repasto sanguíneo no hospedeiro definitivo e, caso estes estejam contaminados, acometem o animal são os dos gêneros Cullex, Aedes e Anopheles. Ao realizarem o repasto sanguíneo, esses vetores liberam larvas L3 que se deslocam para a corrente sanguínea, chegando aos pulmões e ao coração do hospedeiro definitivo (FREITAS, 2017; SILVEIRA, 2018). Esses vetores desenvolvem-se em temperaturas superiores a $15^{\circ} \mathrm{C}$ e elevada umidade relativa. Além disso, as espécies dos gêneros Cullex são ativas exclusivamente durante a noite, enquanto as dos gêneros Aedes e Anopheles, dependendo da espécie, são ativas ao amanhecer, durante o dia ou ao anoitecer (SILVEIRA, 2018).

\subsection{Epidemiologia}

A dirofilariose está presente no mundo inteiro, sendo endêmica em zonas de clima temperado, tropical e subtropical, as quais são áreas favoráveis para o desenvolvimento dos 
hospedeiros intermediários, os mosquitos vetores (CICARINO, 2009). A maturação no interior dos mosquitos pausa em temperaturas abaixo de $14{ }^{\circ} \mathrm{C}$, causando uma redução da transmissão de dirofilariose em meses de inverno (AHS, 2014).

A expansão imobiliária em áreas de baixa incidência da doença e em áreas não endêmicas têm provocado uma maior dispersão e um aumento da prevalência de dirofilariose, devido à alteração no sistema de drenagem dos terrenos naturais, formando-se novas fontes de água nos recentes aglomerados urbanos e, concomitantemente a isso, havendo modificações ambientais, como as modificações naturais, as migrações ou o trânsito de animais que aumenta o potencial de infecção por Dirofilaria immitis (AHS, 2018). Além disso, a expansão urbana levou ao desenvolvimento de "ilhas de calor", consequência de edifícios e estacionamentos que retém calor durante o dia, locais que possuem potencial para o desenvolvimento de larvas de dirofilariose em mosquitos vetores durante os meses mais frios, aumentando, desta forma, o tempo de transmissão (DELLING, 2019).

\subsection{Patogenia}

A severidade da doença associa-se com a carga parasitária, o tamanho do hospedeiro definitivo e a sua capacidade de resposta à infecção (NELSON e COUTO, 2014). Dessa forma, a patogenia está relacionada com a presença de parasitas adultos nas artérias pulmonares, as quais produzem lesões vasculares reativas, desencadeando hipertensão pulmonar e reações inflamatórias, principalmente no ventrículo direito (TAYLOR, 2017).

As células endoteliais são também lesionadas, devido à irritação mecânica desses parasitas, isso faz com que ocorra a aderência de leucócitos ativados e plaquetas. Além disso, fatores tróficos são liberados para estimularem a migração e a proliferação de células musculares lisas, as quais originam as vilosidades endoteliais que causam o estreitamento do lúmen das artérias pulmonares. Logo, este processo inicia um desenvolvimento de trombose e uma reação tecidual perivascular, podendo ocasionar fibrose e lesões pulmonares parenquimatosas (JERICÓ, 2015).

\subsection{Exames laboratoriais}

De acordo com Ettinger e Feldman (2004), os resultados de hemograma, bioquímico e urinálise de cães infectados, em sua maioria, não apresentaram alterações, isso 
pode ser explicado por mudanças transitórias referentes a diferentes estágios da infecção. Alguns dos achados comuns em animais acometidos incluem eosinofilia, basofilia, anemia moderada a crônica, concentração sérica baixa de ferro e trombocitopenia relacionada à morte dos vermes que causam coagulação intravascular disseminada. Caso o animal apresente afecções renais oriundas da doença, hipoalbuminemia e proteinúria podem estar presentes (ETTINGER E FELDMAN, 2014).

\subsection{Diagnóstico}

O diagnóstico de dirofilariose pode ser alcançado mediante a observação dos sinais clínicos e a combinação de diferentes testes, como a pesquisa de microfilárias em amostra de sangue, visualizadas no microscópio através do teste de Knott modificado ou de filtro, a busca por antígenos presentes na circulação, oriundos do trato reprodutivo de larvas adultas fêmeas pelo ensaio imunoadsorvente ligado às enzimas (ELISA) que pode ser feito por meio de kits comerciais ou de testes laboratoriais, e a diferenciação das espécies de microfilária por Reação em cadeia da polimerase (PCR) ou por coloração histoquímica (SILVEIRA, 2018), pois as microfilárias devem ser distinguidas de Aelurostrongylus abstrusus ou Acanthocheilonema reconditum.

Falsos negativos no diagnóstico podem ocorrer dependendo do período de infecção, baixa quantidade de fêmeas adultas e possíveis complexos antígeno-anticorpo que dificultam a detecção de antígenos (AMERICAN HEARTWORM SOCIETY, 2020). Alterações sugestivas de dirofilariose também podem estar presentes em exames de imagem, como a radiografia e o ecocardiograma que, além de prover a avaliação da gravidade da doença, podem complementar o método diagnóstico. No exame radiográfico da porção torácica, a artéria pulmonar pode apresentar-se aumentada e tortuosa, podem ser evidentes modificação do parênquima pulmonar de aspecto difuso e cardiomegalia de lado direito (ETTINGER E FELDMAN, 2014), alterações visualizadas, por exemplo, na radiografia da porção torácica de um cão, representada pela Figura 3. A ecocardiografia pode apresentar caráter diagnóstico quando duas linhas hiperecóicas paralelas estão presentes no ventrículo direito ou na artéria pulmonar e fornece, também, uma análise das lesões causadas pela doença (SILVEIRA, 2018). A eletrocardiografia de cães com dirofilariose, em sua maioria, não demonstram alterações, mesmo na presença de hipertrofia ventricular direita e hipertensão pulmonar (ETTINGER E FELDMAN, 2014), como demonstrado na Figura 4. 
O exame post mortem configura importante método de estudo das lesões a fim de esclarecer o processo patológico da dirofilariose, além de promover um diagnóstico definitivo (CICARINO, 2009). Achados de necropsia em um animal acometido podem incluir áreas hemorrágicas do tecido subcutâneo, presença de líquido livre na cavidade abdominal de caráter serosanguinolento e órgãos congestos. Além disso, são descritos, também, danos ao pulmão, como áreas enfisematosas, edema, hemorragias difusas e vasos com sinais de tromboembolismo. As filárias podem ser encontradas nas artérias pulmonares ou no lado direito do coração (AL-SALIHI et al., 2019). A figura 5 representa um corte transversal do coração de um canino, onde é possível visualizar no ventrículo direito os vermes.

Figura 3. Radiografia de cão acometido por dirofilariose. Aumento de lado direito do coração (formato de D invertido). Fonte: Adaptado de American Heartworm Society (2020).

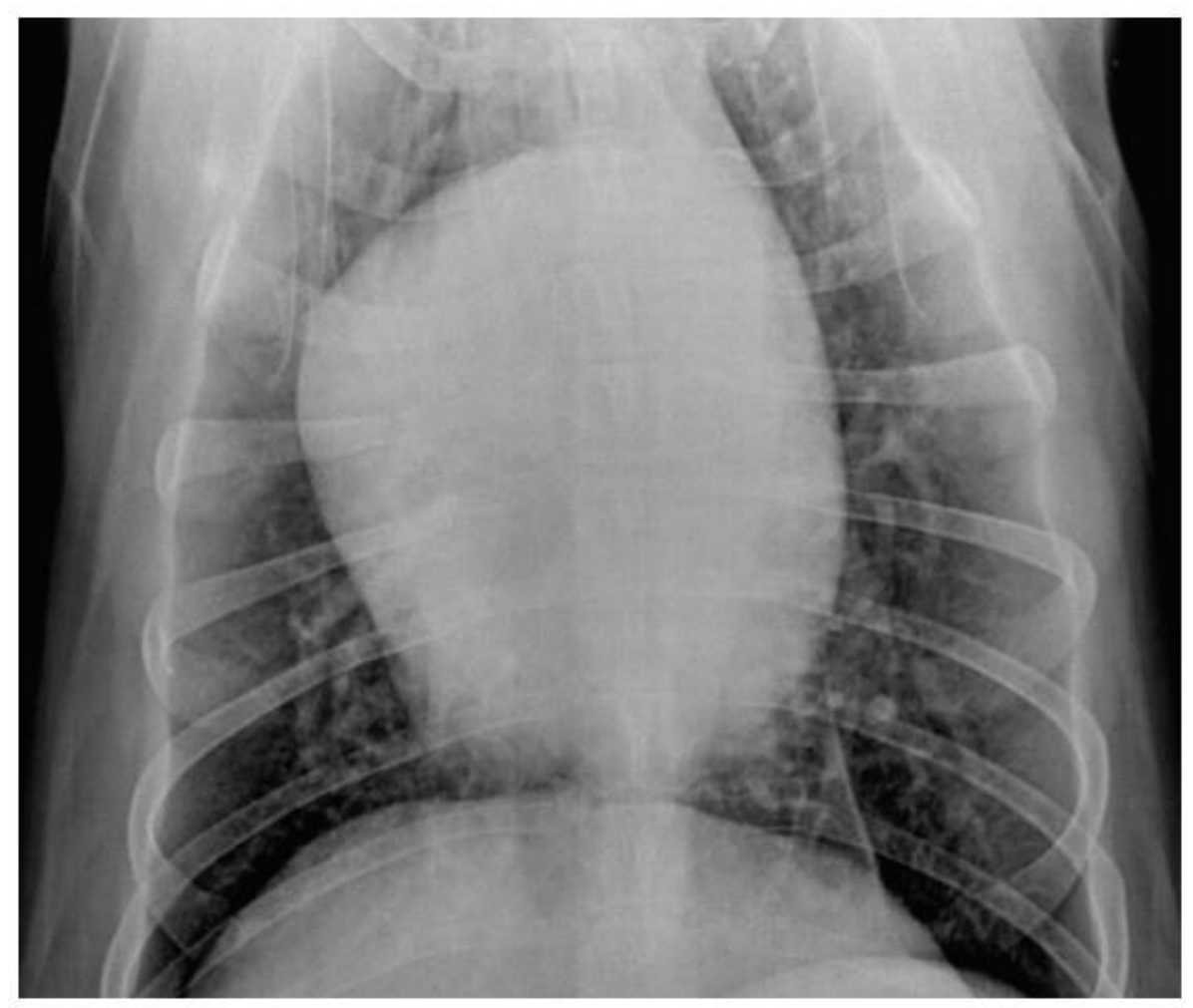


Figura 4. Ecocardiograma apresentando duas linhas paralelas hiperecóicas na artéria pulmonar e válvula tricúspide, indicativo de dirofilariose. LA (átrio esquerdo), LV (ventrículo esquerdo); RV (ventrículo direito); PA (artéria pulmonar). Fonte: Adaptado de American Heartworm Society (2020).

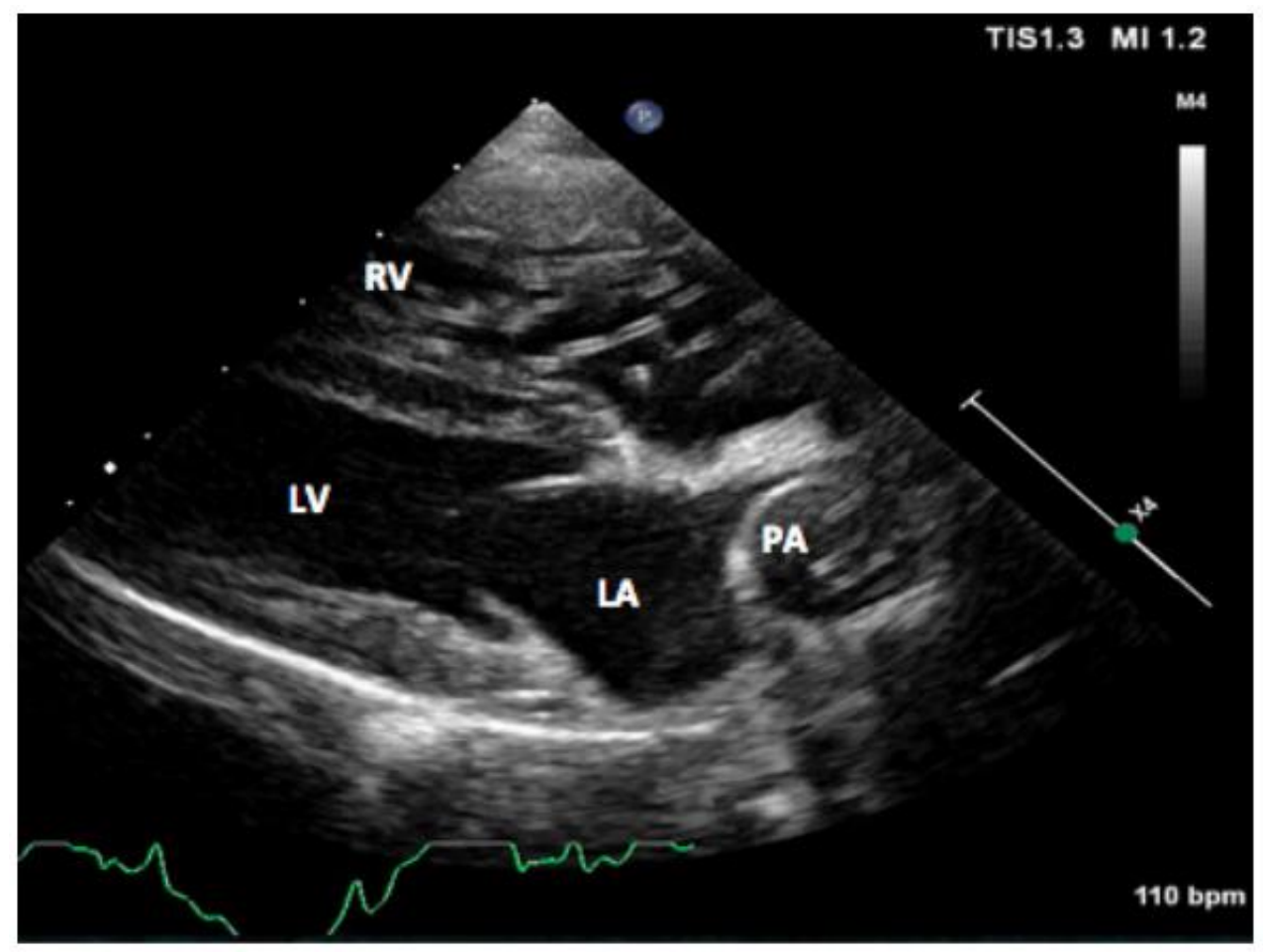

Figura 5. Corte transversal do coração de cão, apresentando exemplares de Dirofilaria immitis no ventrículo direito. Fonte: Adaptado de Almeida (2014).

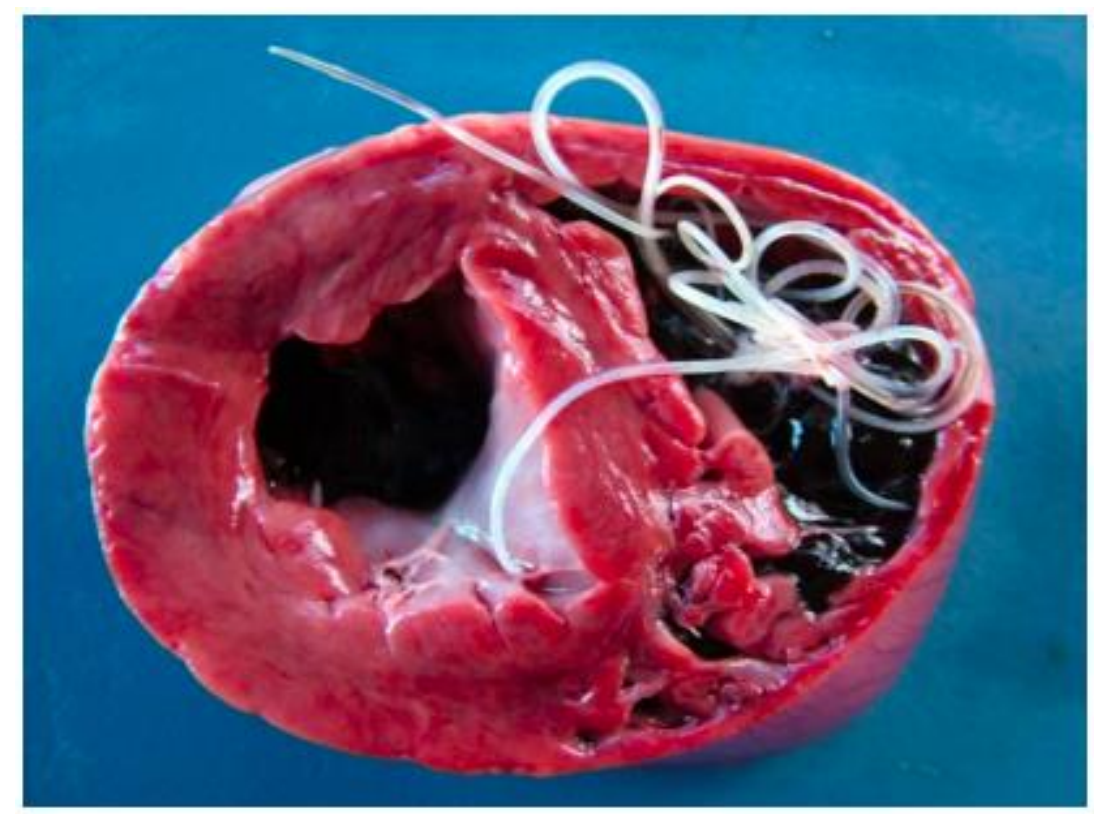




\subsection{Tratamento}

É recomendado como tratamento adulticida de dirofilariose com a associação de uma lactona macrocíclica mensal - 28 dias de $10 \mathrm{mg} / \mathrm{Kg}$ de Doxiciclina oral duas vezes ao dia e três doses de $2,5 \mathrm{mg} / \mathrm{Kg}$ de injeções intramusculares de Dicloridrato de Melarsomina (AMERICAN HEARTWORM SOCIETY, 2020).

A doença é considerada evitável com a administração de lactonas macrocíclicas seguras e eficazes - Ivermectina, Milbemicina, Moxidectina e Selamectina (DIXONJIMENEZ, 2018). As lactonas macrocíclicas servem como removedoras das microfilárias (AMERICAN HEARTWORM SOCIETY, 2020).

A remoção cirúrgica dos vermes adultos é indicada em casos de síndrome da veia cava cranial ou também quando, mesmo não se encaixando na definição da síndrome, o animal possui vermes no coração, pois a remoção cirúrgica é útil para diminuir o volume da infecção, evitando, assim, a síndrome e reduzindo o risco de terapia adulticida subsequente (AMES, 2020).

\section{CONSIDERAÇÕES FINAIS}

A dirofilariose é causada principalmente pela espécie Dirofilaria immitis, haja vista que acomete o hospedeiro definitivo com diversas alterações sintomatológicas e físicas. A transmissão ocorre pela picada de culicídeos dos gêneros Cullex, Aedes e Anopheles infectados por microfilárias. Em vista disso, é importante atentar-se para as áreas endêmicas, as quais são as zonas de clima temperado, tropical e subtropical. Esse verme acomete principalmente a artéria pulmonar e o coração do animal, causando dispneia, tosse e letargia, em geral. O tratamento indicado é a administração de adulticida de dirofilariose com a associação de uma lactona macrocíclica mensal e, em casos de vermes no coração do cão, o tratamento cirúrgico. Portanto, é importante saber sobre essa doença, seus vetores biológicos e os sinais clínicos que o cão pode apresentar, para que, dessa maneira, seja realizado um tratamento adequado em prol do bem-estar do animal. 


\section{REFERÊNCIAS}

ALHO, A. M. et al. Dirofilariose canina e felina, uma parasitose em evolução (I) - Etiologia, Biologia e Epidemiologia. Revista Clínica Animal, v. 2, p. 20-25, 2014.

ALMEIDA, L. M. M. de. Ocorrência de Dirofilaria immitis em cães no semiárido da Paraíba. Monografia (Grau de Médico Veterinário) - Centro de Saúde e Tecnologia Rural, Patos, 2014.

AL-SALIHI et al. Dirofilaria immitis infestation in imported police (K-9) dogs in Iraq: clinicopathological and molecular investigations study, Infecção por Dirofilaria immitis em cães policiais importados no Iraque: estudo clínico-patológico e de investigações moleculares. Brazilian Journal of Veterinary Research and Animal Science, v. 56, n. 2, e152987, 2019.

AMERICAN HEARTWORM SOCIETY. Current Canine Guidelines for the Prevention, Diagnosis, and Management of Heartworm (Dirofilaria immitis) Infection in Dogs. Wilmington, 2020.

AMES, M. K.; ATKINS, C. E. Treatment of dogs with severe heartworm disease. Veterinary Parasitology, v. 283, p. 109-131, 2020.

CICARINO, C. Dirofilariose Canina. Trabalho de Conclusão de Curso (Graduação em Medicina Veterinária) - Centro Universitário das Faculdades Metropolitanas Unidas, São Paulo, 2009.

DELLING, G. F. Dirofilariose em cão da raça pinscher no município de Joinville SC: Relato de caso. Trabalho de Conclusão de Curso (Graduação em Medicina Veterinária) - Centro de Ciências Rurais, Universidade Federal de Santa Catarina, Curitibanos, 2019.

DIXON-JIMENEZ, A. C. et al. Approaches to Canine Heartworm Disease Treatment Among Alumni of a Single College of Veterinary Medicine. Journal of the American Animal Hospital Association, v. 54, n. 5, p. 246-256, 2018.

ETTINGER, S. J.; FELDMAN, E. C. Tratado de medicina interna veterinária doenças do cão e do gato. 5 ed. v. 2. Rio de Janeiro: Guanabara Koogan, 2014.

FREITAS, E. C. B. de. DIROFILARIOSE. REVISTA CONEXÃO ELETRÔNICA, v. 14, p. 314-321, 2017.

JERICÓ, M. M.; DE ANDRADE NETO, J. P.; KOGIKA, M. M. TRATADO DE MEDICINA INTERNA de Cães e Gatos. 1 ed. Rio de Janeiro: Roca, 2015.

MEIRELES, J.; PAULOS, F.; SERRÃO, I. Dirofilariose canina e felina. REVISTA PORTUGUESA DE CIÊNCIAS VETERINÁRIAS, p. 70-78, 2014.

NELSON, R. W., COUTO, C. G. et. al. MEDICINA INTERNA DE PEQUENOS ANIMAIS. Editora Mundial, 5a edição - Elsevier, Rio de Janeiro - RJ, 2015. 
TAYLOR, M. A.; COOP, R. L. WALL, R. L. Parasitologia Veterinária. 4 ed. Rio de Janeiro: GUANABARA KOOGAN, 2017.

PACHECO, A. C. Caracterização da resposta imunoinflamatória na coinfeção Dirofilaria spp. - Wolbachia spp. no cão. Dissertação (Mestrado em Ciências Biomédicas em especialidade em Parasitologia Médica) - Universidade Federal Nova de Lisboa, Instituto de Higiene e Medicina Tropical, Lisboa, 2016.

TRANCOSO, T. A. L. et al. Detecção de Dirofilaria immitis utilizando técnicas microscópicas, imunológicas e moleculares em cães de Cabo Frio, RJ. Revista Brasileira de Parasitologia Veterinária, v. 29, n. 1, 2020. 
ENFERMIDADES E COMPLICAÇÕES PERINATAIS EM POTROS

\section{Julia Carrah Colares}

Universidade Estadual do Ceará (UECE), Faculdade de Veterinária, Fortaleza - Ceará

http://lattes.cnpq.br/4433314772251051

https://orcid.org/0000-0001-6056-763X

\section{José Ryan Ribeiro Tavares}

Centro Universitário Maurício de Nassau (UNINASSAU), Centro de Saúde, Fortaleza - Ceará http://lattes.cnpq.br/8956703680664291

https://orcid.org/0000-0002-4293-4739

\section{Maria Eduarda Magalhães de Souza}

Universidade Estadual do Ceará (UECE), Faculdade de Veterinária, Fortaleza - Ceará

http://lattes.cnpq.br/6200467894630599

https://orcid.org/0000-0003-1280-9600

\section{Ana Beatriz dos Santos Mendes}

Universidade Estadual do Ceará (UECE), Faculdade de Veterinária, Fortaleza - Ceará http://lattes.cnpq.br/3799328282486199

https://orcid.org/0000-0002-3647-4465

\section{Letícia Soares Holanda}

Centro Universitário Maurício de Nassau (UNINASSAU), Centro de Saúde, Fortaleza - Ceará http://lattes.cnpq.br/1931616014306144

https://orcid.org/0000-0002-9411-6885

\section{Máyra Carvalho Petelinkar}

Universidade de Fortaleza (UNIFOR), Centro de Saúde, Fortaleza - Ceará

http://lattes.cnpq.br/5981111350891482

https://orcid.org/0000-0002-7499-4226

\section{Francisco Humberto Marques Sampaio Júnior}

Universidade Estadual do Ceará (UECE), Faculdade de Veterinária, Fortaleza - Ceará http://lattes.cnpq.br/9353106029410768

https://orcid.org/0000-0002-8939-2869

\section{Camila Castelo Trajano}

Universidade de Fortaleza (UNIFOR), Centro de Saúde, Fortaleza - Ceará http://lattes.cnpq.br/2663658854443435

https://orcid.org/0000-0002-1967-7842

\section{Juliana Gomes Vasconcelos}

Universidade Estadual do Ceará (UECE), Faculdade de Veterinária, Fortaleza - Ceará http://lattes.cnpq.br/6104509978041192

https://orcid.org/0000-0001-9739-7320

\section{Victor Hugo Vieira Rodrigues}

Centro Universitário Maurício de Nassau (UNINASSAU), Centro de Saúde, Fortaleza - Ceará http://lattes.cnpq.br/2226604565550002

https://orcid.org/0000-0003-2974-8015 
Informações sobre o

artigo:

Recebido em:

$12 / 08 / 2020$

Aceite em:

$17 / 08 / 2020$

Data de publicação:

$05 / 10 / 2020$

Palavras-chave:

\section{Equinos}

Neonatologia

Patologia

Periparto

\section{RESUMO}

Para que haja o sucesso reprodutivo em equinos, deve-se considerar uma série de influências antes, durante e após o parto, que incluem diversos fatores de risco materno, placentário e fetal. Este trabalho objetivou-se realizar uma revisão de literatura sobre as enfermidades e complicações que acometem os potros durante e após o nascimento, a partir de uma diversidade de artigos científicos e livros sobre o tema. Dessa forma, utilizou-se como método para a escolha da bibliografia dados e conceitos que abordassem sobre este assunto. Com isso, tem-se como resultados que os principais problemas apresentados foram a rejeição do potro, a prematuridade e a dismaturidade, a ressuscitação do neonato, os choques, como o séptico, o hipovolêmico e o cardiogênico, a síndrome de asfixia perinatal e a sepse. Conclui-se, portanto, que para evitar e tratar problemas perinatais em filhotes de equinos e em suas mães, é necessária uma análise qualitativa desde a gestação ao habitat do animal, tendo em vista, principalmente, a alimentação e a qualidade gestacional.

\section{PERINATAL DISEASES AND COMPLICATIONS IN FOALS}

\begin{tabular}{l|l} 
ABSTRACT \\
$\begin{array}{l}\text { In order for reproductive success to occur in horses, a series of } \\
\text { influences must be considered in the before, during and after } \\
\text { delivery, which includes several maternal, placental and fetal risk } \\
\text { factors. This paper aims to perform a literature review on the } \\
\text { diseases and complications that affect foals during and after birth, } \\
\text { out of a variety of scientific articles and books on the topic. } \\
\text { Therefore, data and concepts that addressed the subject were used } \\
\text { as bibliography. As a result, the main disorders presented were the } \\
\text { rejection of the foal, prematurity and dysmaturity, resuscitation of } \\
\text { the newborn, shock such as septic, hypovolemic and cardiogenic, } \\
\text { perinatal asphyxia syndrome and sepsis. Coming to the conclusion, } \\
\text { Equine } \\
\text { that in order to avoid and treat perinatal problems in young colts } \\
\text { and their mothers, a qualitative analysis is necessary from } \\
\text { Pathology } \\
\text { Peripartum } \\
\text { gestational quality. }\end{array}$ \\
\hline
\end{tabular}




\section{INTRODUÇÃO}

Para que haja o sucesso reprodutivo em equinos, deve-se considerar uma série de influências antes, durante e após o parto, que incluem diversos fatores de risco materno, placentário e fetal, como placentite, desnutrição, má formação perineal e lactação precoce, sendo importante avaliar e monitorar as alterações durante a prenhez, a fim de definir estratégias de tratamento voltado à redução desses riscos (AUSTIN, 2013; MCKENZIE, 2018).

Afecções que atinjam o neonato podem gerar complicações graves devido à condição do recém-nascido poder mudar rapidamente, sendo, também, motivada por fatores pré-natais, devendo-se observar a saúde materna placentária na avaliação do potro. Além disso, deve-se considerar, também, o próprio nascimento do neonato, um processo bastante estressante que pode afetar adversamente a saúde deste. Dessa forma, destaca-se que cada complicação é relevante nas formas de problemas clínicos observados no recém-nascido e na sua apresentação (ORSINI, 2011).

Justifica-se este trabalho em virtude da importância da clínica veterinária na prevenção e no tratamento das patologias abordadas e no manejo adequado do animal. Assim sendo, objetivou-se apresentar e discutir os principais problemas que ocorrem no período imediato após o parto, explanando o desenvolvimento dessas enfermidades, bem como as possibilidades terapêuticas a serem adotadas de forma a ampliar os estudos na área da neonatologia equina.

\section{METODOLOGIA}

Para a realização da revisão, utilizou-se como bibliografia periódicos, trabalhos de conclusão de curso e livros, publicados nacional e internacionalmente, no período de 2005 a 2020. A preferência para as fontes escolhidas fora em virtude de estas apresentarem temas que abordaram complicações em equinos neonatos logo após o parto. 


\section{RESULTADOS E DISCUSSÃO}

\subsection{Rejeição do potro}

A rejeição da égua ao potro é caracterizada como uma falha na habilidade materna de reconhecer sua cria e é capaz de se apresentar de diversas formas, por exemplo: a égua pode rejeitar o potro, pode não proteger nem amamentar este ou, ainda, manter uma postura agressiva com o neonato (MCCUE, 2009). Essas problemáticas não são comuns, mas podem trazer diversos prejuízos ao potro, como o atraso ou a ingestão inadequada de colostro, um trauma severo ou o óbito. Assim, geralmente, os potros devem ser separados da égua que os pariu e serem submetidos a um manejo intenso para criá-los e socializá-los ou deve-se encontrar uma égua que os adotem. Segundo Moura (2013), a rejeição de potros representa 9\% das perdas perinatais na raça Crioula, por falha na aquisição da imunidade passiva dos neonatos e nas suas consequências, como sepse e choque.

Acredita-se que o processo de reconhecimento materno do potro inicia-se no parto, quando a égua começa a cheirar o fluido corioalantóide e a placenta, consolidando-se logo após o mesmo quando a mãe começa a lamber o neonato e as membranas fetais, fazendo com que ela consiga o distinguir dos demais e, também, impeça que potros estranhos se aproximem para mamar. McKinnon (2011) acredita que o período crítico para que ocorra essa habilidade materna de reconhecimento da cria é nas primeiras seis horas pós-parto. Dessa forma, a intervenção humana excessiva imediata pode causar alteração no cheiro do filhote (após uso de medicamentos com DMSO, por exemplo), ocasionando, assim, problemas que impeçam a mãe de realizar seu comportamento natural, fato que pode ocorrer em cesarianas e distocias (VAALA, 2011).

Segundo Vaala (2011), a rejeição pode ser dividida em dois grupos: (1) éguas que simplesmente exibem comportamento ambivalente com o potro, devido à inexperiência, problemas no reconhecimento ou anormalidades no neonato; e (2) as que têm medo ou estão ansiosas perto do filhote, principalmente ao amamentar, podendo esse comportamento ser resultado de desconforto devido ao úbere repleto ou a fortes contrações uterinas. Os fatores de risco que predispõem a rejeição materna são a falta de experiência materna (éguas primíparas), histórico de multíparas que já rejeitaram dois ou mais potros, éguas da raça árabe e as que não tiveram contato com potros durante seu desenvolvimento (HOUPT, 2009).

Quando a mãe dá sinais de rejeição ao potro, o importante é garantir a segurança deste enquanto se investiga a causa e a possível reversibilidade do comportamento anormal 
da égua, além de mantê-lo nutrido e hidratado. Se não for possível o potro mamar, deve-se oferecer uma quantidade de leite equivalente a $10 \%$ do peso corporal do animal por dia, sendo preferencial o uso da mamadeira por estimular o comportamento de sucção (VAALA, 2011).

Reintroduzir a placenta a certas éguas pode estimular a resposta olfativa que inicia o processo de reconhecimento, principalmente se o parto foi anormal ou demorado. As éguas que apresentam desconforto devido ao parto devem receber terapia com drogas analgésicas e anti-inflamatórias, como Flunixin Meglumine - 0,5 - 1,0 mg/Kg, por terapia intravenosa (IV) - para aliviar a dor e permitir que a égua volte sua atenção para o potro. Quando o desconforto é proveniente do úbere repleto, além do anti-inflamatório, pode-se realizar compressas frias e uma baixa dose de ocitocina - 5 UI por terapia intravenosa (IV) ou injeção intramuscular (IM) - para facilitar a ejeção do leite durante a ordenha. Em casos mais complicados, pode-se fazer uso de tranquilizantes, como a Acepromazina $(0,03$ - 0,066 $\mathrm{mg} / \mathrm{Kg}$ IV/IM), que também tem potencial de estimular a lactação através da liberação de prolactina.

Uma vez que a égua esteja calma, deve-se observar seu comportamento realizando um teste simples de colocar o potro em um lugar, fora da baia, para que ela não consiga vêlo. Se com essa separação ela ficar ansiosa e vocalizar é um bom sinal de que aceitará o filhote (VAALA, 2011).

Algumas medidas podem ser tomadas para tentar evitar a rejeição pós-parto, como acostumar a égua ao local do parto algumas semanas antes, disponibilizar um ambiente tranquilo sem trânsito de pessoas e que não tenha contato visual com outros cavalos e, por fim, evitar intervenção humana desnecessária nas primeiras horas após o parto (VAALA, 2011; MCKINNON, 2011).

Vaala (2011), defende o uso de terapia hormonal preventiva em éguas que já apresentam histórico de rejeição a potros. O protocolo do autor inclui o uso de uma combinação de drogas por três a cinco dias: Altrenogest $(0,044 \mathrm{mg} / \mathrm{Kg}$ oral a cada 12 - 24 horas), Benzoato de Estradiol (10 mg IM a cada 24 horas) e Domperidona (1.1 mg/Kg oral a cada 12 - 24 horas). Berlin e Raz (2018) observaram que a relação de estradiol:progesterona aumentou de um a três dias após o parto em éguas que rejeitaram potros. 


\subsection{Prematuridade e dismaturidade}

O potro prematuro é aquele que nasce antes do período gestacional, já o dismaturo é aquele que atinge a idade gestacional adequada, porém apresenta sinais de imaturidade. Portanto, é importante notar que, apesar de existir uma média de 320 a 360 dias de gestação para a espécie equina, essa faixa varia bastante não só de acordo com a raça, mas também pode variar entre cada indivíduo. Dessa forma, se determinada égua tem histórico de gestações que durem por volta de 360 dias vier a parir um potro com 320 dias, apesar de ele estar teoricamente na faixa ideal, ele é um potro prematuro (PARADIS, 2006). Assim, é de extrema importância que se mantenha um acompanhamento da duração do parto das éguas (FEIJÓ, 2014).

O final da maturação do organismo do feto, em específico a maturação do córtex adrenal, ocorre durante as 72 horas pré-parto, devido ao pico de produção de cortisol que ocorre nesse período, que irá ativar a maturação dos sistemas do feto. Dessa forma, quanto mais próximo do tempo ideal de gestação, maior será a capacidade de resposta do neonato ao ambiente externo, já que ele irá apresentar órgãos maturados e prontos para reagirem a estímulos (FEIJÓ, 2014).

Os sinais clínicos de imaturidade neonatal serão condizentes com a falha da maturação final dos sistemas do feto. Dentre as principais características do potro imaturo estão: pequeno porte, pelagem curta e fina, baixo tônus muscular, cabeça acarneirada, persistência de cápsula decídua, hipoflexão dos membros e flacidez de orelhas, língua e lábios. Ainda, é comum que esses potros apresentem demora para ficar em estação, ausência de reflexo de sucção e alienação em relação à mãe (PARADIS, 2006; FEIJÓ, 2014).

A maioria dos potros prematuros ou dismaturos serão menores do que seus pares durante os primeiros 12 - 18 meses de vida, mas essa diferença física torna-se menos perceptível depois desse período (LESTER, 2011).

O manejo bem-sucedido do potro prematuro ou dismaturo requer antecipação e reconhecimento precoce dos problemas. A maioria experimentará algum grau de insuficiência pulmonar caracterizada por redução da capacidade de ventilação, taquipnéia, hipoxemia e vários níveis de hipercapnia, cuja gravidade está intimamente ligada à maturação do eixo hipotálamo-hipófise-adrenal (LESTER, 2011). O tratamento depende da gravidade da disfunção, mas a maioria dos potros beneficia-se do oxigênio umidificado intranasal. Potros prematuros e dismaturos são mais suscetíveis à hipotermia do que potros a termo. A 
temperatura corporal precisa de tratamento cuidadoso, pois o aquecimento rápido pode resultar em vasodilatação periférica e possível colapso cardiovascular (LESTER, 2011).

Embora alguns casos de prematuridade e dismaturidade tenham causa idiopática, a maior parte dos casos está associada a placentites e outras afecções que comprometam o útero e a placenta ou, ainda, por iatrogenia, seja por indução eletiva do parto feita precocemente, devido ao registro impreciso da data estimada para o parto ou por má interpretação de cólicas tardias (PARADIS, 2006; FEIJÓ, 2014).

O prognóstico de potros prematuros vai depender do motivo da prematuridade do parto, para que dessa forma o potro possa ter os cuidados específicos para seu caso, e de uma intervenção terapêutica precoce. Com cuidados intensivos, cerca de $80 \%$ dos casos apresentam resultados favoráveis, embora potros que apresentem alterações musculoesqueléticas geralmente não podem se tornar atletas (LESTER, 2005; PARADIS, 2006).

\subsection{Ressuscitação do potro}

Os primeiros 20 segundos após o nascimento são utilizados para avaliar a respiração do potro, pois este pode apresentar problemas cardiorrespiratórios. Os sintomas mais comuns são: alteração do estado mental, bradipneia $(<10 \mathrm{rpm})$ ou respiração irregular, midríase, terapia de ressincronização cardíaca prolongada, taquicardia ou taquiarritmias, pressão arterial média inferior a $40 \mathrm{mmHg}$, elevações significativas na concentração plasmática de lactato, anúria ou oligúria (FIELDING e MAGDESIAN, 2003). Para a realização da reanimação, o animal precisa estar em decúbito lateral na superfície plana e dura para que as compressões torácicas sejam realizadas adequadamente. Além disso, a cabeça deve estar ereta, evitando levantá-la. Se o equino apresentar costelas fraturadas o lado do decúbito deve ser correspondente a fratura.

Posteriormente, devem ser removidas as membranas fetais das vias nasais e da boca do animal, para que este respire de forma espontânea. $\mathrm{O}$ uso de toalhas na região do tórax também é válido para estimular a respiração. Se houver dificuldade para respirar, o potro precisa de uma ventilação através de intubação nasotraqueal, onde a sonda passa pela via nasal de forma cuidadosa para não haver complicações com o filhote. Se após duas tentativas de intubação nasotraqueal não serem bem-sucedidas, as próximas deverão ser realizadas pela boca (CORLEY e AXON, 2005). Após as ventilações, deve ser observado as condições 
respiratórias do animal, para observar se houve positividade no procedimento realizado no potro.

\subsection{Choque séptico, hipovolêmico e cardiogênico}

O choque é uma condição de inadequado abastecimento de oxigênio e substratos nutritivos para os tecidos, devido à instabilidade cardiovascular. Caracteristicamente, a hipotensão é induzida pelo choque resultando em hipoperfusão e disfunção orgânica. Sua classificação baseia-se na etiologia, sendo as principais em potros neonatos o choque hipovolêmico, o choque cardiogênico e o choque séptico ou síndrome da resposta inflamatória sistêmica (SIRS). Etiologias menos comuns incluem anemia grave, anafilaxia e choque neurogênico (MCKINNON, 2011).

O choque hipovolêmico pode resultar de redução de ingestão de líquidos, hemorragia ou perdas de líquidos e/ou plasma. O choque cardiogênico pode ocorrer devido a qualquer anormalidade cardíaca que diminua a capacidade de distribuição sanguínea, produzindo, assim, uma redução acentuada no débito cardíaco e hipotensão (MCKINNON, 2011). A SIRS é uma resposta inflamatória inata a uma série de graves insultos clínicos, como infecções bacterianas, infecções virais, endotoxemia, trauma, queimaduras, isquemia e hipóxia. Muitos mediadores estão envolvidos na SIRS e esta pode resultar no desenvolvimento de choque. SIRS causada por infecção é denominado sepse. Choque induzido por SIRS, devido a sepse e síndrome asfixial perinatal, são as causas mais comuns de distúrbios hemodinâmicos em potros neonatos (DELLINGER, 2013).

A resposta inicial do organismo a progressão do choque é a diminuição do débito cardíaco, como resultado de uma combinação de volume sanguíneo reduzido, pressão venosa diminuída, diminuição da pré-carga cardíaca e/ou redução na contratilidade miocárdica. A vasoconstrição venosa simpática reduz a capacitância da circulação periférica, resultando em um aumento do retorno venoso que inicialmente aumenta o débito cardíaco. Vasoconstrição arterial preserva inicialmente a pressão sanguínea através de um aumento da resistência, mas, como a perda de volume sanguíneo continua, a perfusão é desviada de áreas não essenciais como a pele e os rins. Como resultado, as extremidades periféricas esfriam, o tempo de preenchimento capilar aumenta e a oligúria se desenvolve. O sangue é também desviado da circulação esplâncnica, resultando no íleo paralítico e leve distensão abdominal (MCKINNON, 2011). 
A apresentação da maioria dos potros em choque será suprimida, devido à hipotensão e a uma progressiva redução da perfusão cerebral. Mudanças na frequência da amamentação podem ser aparentes apenas 2 - 3 horas após o início do choque cardiovascular. Os sinais clínicos de hipoperfusão incluem as extremidades frias, a baixa qualidade de pulso, o tônus arterial e o preenchimento arterial, a alteração de coloração de mucosa, o tempo prolongado de preenchimento capilar e a presença de petéquias ou equimoses (STERLING, 2015).

Taquicardia (frequência cardíaca $>120$ batimentos/min) pode ser identificada em potros em estado de choque, mas frequentemente a frequência cardíaca pode estar dentro da faixa normal (70 - 103 batimentos/min), apesar da hipoperfusão significativa. Bradicardia (frequência cardíaca < 60 batimentos/min) é geralmente associado à hipóxia. Taquipnéia (frequência respiratória $>40$ respirações $/ \mathrm{min}$ ) pode estar presente em resposta à hipoxemia e, também, como resposta respiratória compensatória, a acidose metabólica. A temperatura retal pode ser hipertérmica (temperatura retal $>39,2{ }^{\circ} \mathrm{C}$ ), normotérmica ou hipotérmica (temperatura retal $\left.<37,2^{\circ} \mathrm{C}\right)(\mathrm{CORLEY}, 2005)$.

O diagnóstico baseia-se na anamnese associada aos sinais clínicos e achados laboratoriais (MCKINNON, 2011). O tratamento do choque visa garantir a perfusão para leitos vasculares essenciais (coronários, cerebrais, hepáticos e renais) e prevenir ou corrigir anormalidades metabólicas decorrentes de hipoperfusão celular. O oxigênio intranasal é administrado inicialmente a taxas de 5 a $10 \mathrm{~L} / \mathrm{min}$ para maximizar a concentração de oxigênio no sangue, compensando possíveis incompatibilidades de ventilação-perfusão. A perda de calor deve ser minimizada pela secagem manual do potro com toalhas. Para aumentar a pré-carga ventricular, o volume sistólico e, portanto, débito cardíaco na hipovolemia, fluidos intravenosos (cristalóides e colóides) são comumente administrados. Se a hipotensão persistir antibióticos, produtos derivados de sangue e vasoconstritores devem ser considerados. O objetivo final é restaurar a perfusão e oxigenação dos tecidos (WONG, 2018).

\subsection{Síndrome da asfixia perinatal}

Síndrome da asfixia perinatal (PAS), trata-se de uma série de sinais clínicos decorrentes da falta de oxigenação celular, tendo como causa hipoxemia, juntamente com isquemia (RIZZONI e MIYAUCHI, 2012). A PAS pode acometer potros desde o terço final 
da gestação até trinta dias de vida, sendo que a maioria dos potros acometidos são afetados durante o nascimento (RIZZONI e MIYAUCHI, 2012; CAMILLO, 2016).

Os fatores maternos mais comumente associados à patologia são aqueles que alteram o fluxo sanguíneo uteroplacentário, como insuficiência placentária, muitas vezes acompanhada por anemia, hipoproteinemia e endotoxemia. Já os fatores pós-parto, estão relacionados às doenças que causam interrupção da distribuição normal do fluxo sanguíneo (CAMILLO, 2016) e oxigenação do organismo, como afecções do aparato respiratório (hipoplasia pulmonar, pneumonia, disfunção de surfactante, edema ou congestão pulmonar, hérnia diafragmática e pleurites), alterações como a anemia, acidose e hipoglicemia, e também lesões do sistema nervoso central, atelectasia, insuficiência cardíaca e persistência da circulação fetal (RIZZONI e MIYAUCHI, 2012).

Os principais sinais clínicos observados em potros acometidos pela síndrome são: desproporção entre cabeça e corpo, sintomatologia neurológica comportamental, como incapacidade de encontrar o úbere, perda de afinidade com a égua, baixa resposta a estímulos externos, sonolência, que pode evoluir para depressão severa e coma. Os potros podem apresentar, ainda, sinais como hiperexcitação e inquietação, intercalados com a sonolência. Outros sinais clínicos comuns são: fraqueza, disfagia, cegueira, pouco tônus muscular nos membros e língua, incapacidade de termorregulação (CAMILLO, 2016).

O diagnóstico, normalmente, é bastante limitado, uma vez que em outras afecções, como sepse neonatal, hipoglicemia e prematuridade podem ocorrer os sintomas observados em potros essa síndrome. Desse modo, o diagnóstico deve-se basear no histórico do animal e identificação de déficits neurológicos, excluindo outras enfermidades do sistema nervoso central (GOLD, 2015). Vaala et al. (2009) cita alguns critérios de diagnóstico que englobam o histórico de anormalidades do periparto, desenvolvimento de déficits neurológico em potros nas primeiras 24 a 72 horas e observação de alguma outra causa de distúrbio no sistema nervoso central, como meningite séptica ou distúrbios eletrolíticos. O hemograma e bioquímico apresentam-se normais, a menos que haja sepse ou outro problema envolvido, assim como o líquido cefalorraquidiano, normalmente encontra-se normal, exceto em casos de trauma, em que pode haver xantocromia (KNOT'TENBELT, 2006). A acidose metabólica pode estar presente, com $\mathrm{pH}<7$, e a concentração sérica de bicarbonato pode se apresentar menor que $20 \mathrm{mEq} / \mathrm{L}$, além da concentração de creatinina acima de 3,5 mg/dL em casos de insuficiência placentária pré-parto, que pode estar associada à azotemia neonatal (VAALA et al, 2009). A tomografia computadorizada e a ressonância magnética são modalidades mais recentes utilizadas para avaliar lesões no sistema nervoso central (VAALA et al., 2009). 
A terapia indicada deve ser de suporte e depende dos múltiplos sistemas envolvidos. O tratamento de eleição envolve a manutenção de glicose, suporte de oxigênio, controle e manutenção da pressão sanguínea, assim como o uso de antioxidantes e neuroprotetores (GOLD, 2015). Mckinnon et al. (2011) indicam para o controle das convulsões o Midazolam $(0,1-0,2 \mathrm{mg} / \mathrm{Kg}$ ou 5 - $10 \mathrm{mg}$ a um potro de $50 \mathrm{Kg}$, IM ou IV) ou Diazepam (0,1 - 0,2 $\mathrm{mg} / \mathrm{Kg}$ ou 5 - $10 \mathrm{mg}$ para um potro de $50 \mathrm{Kg}$, IM ou IV) para controle de convulsões emergenciais e, em casos em que haja mais que duas convulsões, indica-se a substituição Diazepam por Fenobarbital (2 - $5 \mathrm{mg} / \mathrm{Kg}$, IV) ou a infusão de taxa constante de Midazolam (3 - $6 \mathrm{mg} / \mathrm{h}$ ). Além disso, para o controle do edema cerebral que se manifesta geralmente nos casos mais graves, pode-se utilizar Manitol $(0,25$ - 1,0 g/Kg, IV), realizando a administração com cautela, uma vez que pode exacerbar a hemorragia intracraniana e que doses excessivas podem provocar alterações significativas na osmolaridade plasmática, além do uso de Dimetilsufóxido (DMSO; 0,5 - 1,0 g/Kg, IV).

A hipoventilação e acidose respiratória, provocadas devido à hipóxia-isquemia, tornam necessária a realização de oxigênioterapia, administrada por tubo nasal, até que a pressão de oxigênio seja superior a $150 \mathrm{mmHg}$, devendo-se manter a sonda nasal. A fluidoterapia é essencial, porém deve ser realizada apenas de manutenção para evitar o agravamento do edema cerebral. Tendo em vista o alto risco de sepse por infecção uterina, translocação bacteriana intestinal e baixas concentrações de $\operatorname{IgG}$, é necessário a administração de antimicrobianos, como Amicacina (25 mg/Kg, IV), Penicilina (15 000 - 25 $000 \mathrm{IU} / \mathrm{Kg}$, IV), ou Ticarcilina (40 - $50 \mathrm{mg} / \mathrm{Kg}$ por IV) (TORIBIO, 2019).

O prognóstico para potros em que a afecção é reconhecida e tratada precocemente varia de bom a excelente, enquanto que para potros com tratamento tardio ou ineficaz e com problemas concomitantes, como sepse e prematuridade, o prognóstico reduz (MCKINNON et al., 2011). Além disso, o prognóstico para potros acometidos com traumas na cabeça ou pescoço depende da gravidade da lesão provocada (PARADIS, 2006).

\subsection{Sepse}

Segundo Mackinnon (2011), a sepse se trata de uma resposta inflamatória sistêmica associada a um processo infeccioso confirmado. A sepse resulta de uma falha na resposta imune inata do neonato contra a infecção, levando geralmente a disfunções nos órgãos, hipotensão, e infecções localizadas (MAGDESIAN, 2017), sendo caracterizada pelas seguintes manifestações clínicas: depressão, letargia, ausência ou diminuição do reflexo de 
sucção, desidratação, mucosas hiperêmicas, febre, taquicardia, taquipnéia ou hiperventilação, leucocitose, leucopenia e aumento do número de neutrófilos imaturos na circulação sanguínea (MCKINNON et al., 2011).

A sepse representa uma das causas mais significativas de enfermidade e óbito em potros neonatos (FIELDING e MAGDESIAN, 2015). A infecção dos neonatos pode ocorrer devido a vários fatores, tendo eles origem durante a gestação como enfermidades da égua durante a gestação, alterações no período gestacional, falha na transferência da imunidade passiva, condições sanitárias precárias, entre outras originadas no parto ou no pós parto (MCKINNON et al., 2011).

Existem alguns fatores que podem estar associados ao desenvolvimento de sepse em um neonato, e, por isso, devem ser observados. Os fatores relacionados ao momento pré-parto são a lactação prematura, a secreção vaginal, o aparecimento dos sinais de trabalho de parto antes do tempo, e as doenças maternas, como cólica e placentite. Durante o trabalho de parto, deve-se observar a duração de cada estágio, a presença de fluidos com aparência anormal e a aspiração do mecônio. Já após o parto, os fatores mais preocupantes são a demora para adotar posição esternal e para mamar, o comportamento anormal do potro e da égua e a contaminação do ambiente (FIELDING e MAGDESIAN, 2015).

Alguns fatores maternos, como a placentite, a distocia e a separação prematura da placenta podem predispor o neonato a uma infecção. O que ressalta a importância do acompanhamento do parto, a observação da placenta da placenta e a avaliação do potro na escala Apgar, e a avaliação da transferência da imunidade passiva. Um potro que nasce já debilitado é mais suscetível aos fatores ambientais e ao desenvolvimento de infecções (FIELDING e MAGDESIAN, 2015).

O ambiente em que o neonato se encontra no pós-parto está repleto de microrganismos que podem facilmente ganhar acesso à circulação sanguínea do potro, seja por inalação, ingestão ou por soluções de continuidade. Até mesmo a égua é uma possível fonte de contaminação, seja por contaminação via umbilical ou durante a amamentação e o parto pelo contato com os microrganismos da flora natural da égua (PARADIS, 2006).

O potro, apesar de nascer imunocompetente, ainda é incapaz de montar uma resposta imunológica rápida e eficiente contra os inúmeros patógenos no ambiente, se tornando suscetível, a menos que ocorra a ingestão de quantidade adequada de colostro. Dessa forma, a falha na transferência de imunidade passiva deve ser monitorada através da mensuração da quantidade de imunoglobulinas no soro do potro, que não devem estar abaixo de $800 \mathrm{mg} / \mathrm{dL}$ (MAGDESIAN, 2017). 
O exame físico feito pelo médico veterinário é essencial para observar a presença ou não de sinais associados à sepse e é também a forma mais confiável de reconhecer a afecção. Algumas alterações que podem ser detectadas são: articulações edemaciadas, umbigo aumentado, petéquias nas mucosas, baixa temperatura nas extremidades, alto tempo de preenchimento capilar, baixa frequência em urinar, entre outras (FIELDING e MAGDESIAN, 2015).

O padrão ouro para confirmação do diagnóstico de sepse é a hemocultura que permite a identificação da bactéria presente na corrente sanguínea. No entanto, na rotina veterinária não é possível esperar o resultado da cultura (48 - 72 horas) para iniciar o tratamento do neonato. A cultura microbiológica apresenta inúmeras limitações, sendo sua principal o tempo necessário para sua feitura, mas, também, a alta ocorrência de falsos negativos e a dificuldade de isolar alguns patógenos mais fastidiosos ou que precisem de condições bastante específicas para se proliferar (WONG et al., 2018).

Potros com suspeita de sepse devem receber terapia com antibióticos de amplo espectro que afetem tanto bactérias gram positivas como gram negativas. Fluidoterapia também é necessária, agindo de forma a restaurar a perfusão tecidual. O tratamento com anti endotoxinas é imprescindível para reverter a endotoxemia. Já a transfusão de plasma é uma boa opção para prover suporte imunológico (MCKINNON, 2011).

Por fim, é necessário garantir o suporte nutricional do potro, podendo ser necessária a nutrição parenteral se ele apresentar perda de reflexo e sucção. Ainda, alguns tratamentos específicos podem vir a ser necessários, como a lavagem de articulações acometidas com fluidos estéreis, oxigenioterapia e utilização tópica de antibióticos em casos de úlcera de córnea (MCKINNON, 2011).

Segundo McKinnon (2011), centros de referência em tratamento neonatal reportaram uma taxa de $50 \%$ a $80 \%$ de sobrevivência em casos de sepse em potros. O prognóstico de potros acometidos com sepse varia com a severidade do caso e os sinais clínicos manifestados, sendo que o diagnóstico precoce juntamente com o tratamento intensivo aumenta as chances de sobrevivência.

\section{CONSIDERAÇÕES FINAIS}

Para evitar complicações e enfermidades com potros no período pós-parto é importante reconhecer e prevenir, desde o início, problemas ligados à mãe, à alimentação e 
à saúde, para permitir que o animal se desenvolva com todo seu potencial e adquira um bom desempenho em suas atividades futuras. Além disso, o conhecimento sobre os hábitos e comportamentos naturais dos potros auxilia no correto manejo com estes animais. Desta forma, um manejo adequado das crias e das mães, as medidas profiláticas de sanidade e uma boa escrituração zootécnica são imprescindíveis para evitar patologias e garantir o desenvolvimento adequado e saudável do potro e o sucesso da criação.

\section{REFERÊNCIAS}

AUSTIN, S. M. Assessment of the equine neonate in ambulatory practice. Equine Veterinary Education, v. 25, n. 11, p. 585-589, ago. 2013.

BERLIN, D.; STEINMAN, A.; RAZ, T.; Post-partum concentrations of serum progesterone, oestradiol and prolactin in Arabian mares demonstrating normal maternal behaviour and Arabian mares demonstrating foal rejection behaviour. The Veterinary Journal, v. 232 p. 40-45, 2018.

CAMILLO, J. C. Síndrome de asfixia perinatal em potros. 2014. 48 f. Trabalho de Conclusão de Curso (Bacharelado)-Curso de Medicina Veterinária, Universidade Federal do Recôncavo da Bahia, Cruz das almas, 2016.

CORLEY, K. T. T.; AXON J. E. Resuscitation and emergency management for neonatal foals. Veterinary Clinics of North America: Equine Practice, v. 21, n. 2, p. 431-455, aug 2005.

FEIJÓ, L. S. et al. Maturity of foals from the mares with placentitis. Arquivo Brasileiro de Medicina Veterinária e Zootecnia, v. 66, n. 6, p. 1662-1670, 2014.

FIELDING C.; MAGDESIAN, K. Cardiopulmonary Cerebral Resuscitation in Neonatal Foals. Clinical Techniques in Equine Practice, v. 2, n. 1, p. 9-19, 2003.

FIELDING, C. L.; MAGDESIAN, K. G. Sepsis and septic shock in the equine neonate. Veterinary Clinics: Equine Practice, v. 31, n. 3, p. 483-496, 2015.

GOLD, J. R. Perinatal asphyxia syndrome. Equine Veterinary Education, v. 29, n. 3, p. 158-164, dez. 2015.

HOUPT, Katherine A. Foal rejection. In: ROBINSON N. E.; SPRAYBERRY K. (Eds.). Current Therapy in Equine Medicine, 6th edn. Philadelphia: WB Saunders Co., 2009. p. $116-118$

KNOTTENBELT, D. C.; HOLDSTOCK, N.; MADIGAN, J. E. Equine Neonatology: Medicine and Surgery. Philadelphia: Elsevier, 2006.

LESTER, G. D. Maturity of the neonatal foal. Veterinary Clinics: Equine Practice, v. 21, n. 2, p. 333-355, 2005. 
LESTER, G. D. Prematurity, Dysmaturity and Assessment of Maturity. In: MCKINNON, A.O.; SQUIRES, E.; VAALA, W. E.; VARNER, D. D. (Eds.). Equine Reproduction, 2. ed., Blackwell Publishing Ltd, 2011.

MAGDESIAN, K. G. Antimicrobial pharmacology for the neonatal foal. Veterinary Clinics: Equine Practice, v. 33, n. 1, p. 47-65, 2017.

MCCUE, Patrick M. Foal Rejection. In: DASCAINO, J. J.; MCCUE, P. M. (Eds.). Equine Reproductive Procedures, Colorado State University: Wiley Online Library, 2014. p. $527-$ 529.

MCKENZIE, H. C. Disorders of Foals. Equine Internal Medicine, p. 1365-1459, 2018. MCKINNON, A. O. et al. Equine Reproduction. 2 ed. Nova Delhi: Wiley- blackwell, 2011, $3310 \mathrm{p}$.

MCKINNON, Ao. Peri-parturient problems. In: TERCER CONGRESO ARGENTINO DE REPRODUCCIÓN EQUINA. E-book. Rio Cuarto: Unirio, 2013. p. 8-26.

MOURA, E, M. Perdas perinatais em éguas da raça crioula. 2013. 33 f. Trabalho de conclusão de curso (Bacharelado)-Curso de Zootecnia, Universidade Federal do Pampa. Dom Pedrito, 2013.

ORSINI, J. A. A fresh look at the process of arriving at a clinical prognosis. Part 3: Neonatal illness. Journal of Equine Veterinary Science, n. 31, p. 434-446, 2011.

PARADIS, M. R. Equine Neonatal Medicine: A case-based approach. Philadelphia: Elsevier, 286 p, 2006.

RHODES A. et al. Surviving Sepsis Campaign: international guidelines for management of severe sepsis and septic shock. Critical Care Medicine, 2016. p. 580-637.

RIZZONI, L. B.; MIYAUCHI, T. Principais doenças dos neonatos equinos. Acta Veterinaria Brasilica, v. 6, n. 1, p. 9-16, 2012.

STERLING S. A. et al. The impact of timing of antibiotics on outcomes in severe sepsis and septic shock: a systematic review and meta-analysis. CritIcal Care Medicine, vol. 43, n. 9, p. 1907-1915, sep. 2015.

TORIBIO, R. E. Equine Neonatal Encephalopathy: facts, evidence and opinions. Veterinary Clinics Of North America: Equine Practice, v. 35, n. 2, p. 363-378, ago. 2019.

VAALA, W. E. Perinatal asphyxia Syndrome in Foals. Compedium Equine: Continuing Education for Veterinarians, p. 134-140, abr. 2009.

VAALA, W.E.; Foal rejection. In: MCKINNON; Equine Reproduction, 2011.

WONG D. M. et al. Evaluation of updated sepsis scoring systems and systemic inflammatory response syndrome criteria and their association with sepsis in equine neonates. Journal of Veterinary Internal Medicine, v. 32, n. 3, p. 1185-1193, may 2018. 
WONG, D. M. et al. Evaluation of updated sepsis scoring systems and systemic inflammatory response syndrome criteria and their association with sepsis in equine neonates. Journal of veterinary internal medicine, v. 32, n. 3, p. 1185-1193, 2018. 


\title{
ENRIQUECIMENTO AMBIENTAL PARA GRANDES FELINOS EM CATIVEIRO: REVISÃO DE LITERATURA
}

\author{
Máyra Carvalho Petelinkar \\ Universidade de Fortaleza (UNIFOR), Centro de Saúde, Fortaleza - Ceará \\ http://lattes.cnpq.br/5981111350891482 \\ https://orcid.org/0000-0002-7499-4226
}

\section{Francisco Humberto Marques Sampaio Júnior}

Universidade Estadual do Ceará (UECE), Faculdade de Veterinária, Fortaleza - Ceará

http://lattes.cnpq.br/9353106029410768

https://orcid.org/0000-0002-8939-2869

\section{Letícia Soares Holanda}

Centro Universitário Maurício de Nassau (UNINASSAU), Centro de Saúde, Fortaleza - Ceará http://lattes.cnpq.br/1931616014306144

https://orcid.org/0000-0002-9411-6885

\section{Camila Castelo Trajano}

Universidade de Fortaleza (UNIFOR), Centro de Saúde, Fortaleza - Ceará

http://lattes.cnpq.br/2663658854443435

https://orcid.org/0000-0002-1967-7842

\section{José Ryan Ribeiro Tavares}

Centro Universitário Maurício de Nassau (UNINASSAU), Centro de Saúde, Fortaleza - Ceará http://lattes.cnpq.br/8956703680664291

https://orcid.org/0000-0002-4293-4739

\section{Julia Carrah Colares}

Universidade Estadual do Ceará (UECE), Faculdade de Veterinária, Fortaleza - Ceará http://lattes.cnpq.br/4433314772251051

https://orcid.org/0000-0001-6056-763X

\section{Victor Hugo Vieira Rodrigues}

Centro Universitário Maurício de Nassau (UNINASSAU), Centro de Saúde, Fortaleza - Ceará http://lattes.cnpq.br/2226604565550002

https://orcid.org/0000-0003-2974-8015

Informações sobre o

artigo:

Recebido em:

$29 / 08 / 2020$

Aceite em:

$31 / 08 / 2020$

Data de publicação:

$05 / 10 / 2020$

\section{RESUMO}

O bem-estar animal é fundamental para a manutenção da saúde e do sucesso da conservação de animais em cativeiro que podem sofrer de atitudes atípicas e estereotipadas quando comportamentos naturais não podem ser expressados. Dessa forma, objetivou-se neste trabalho realizar uma revisão bibliográfica com levantamento de trabalhos atualizados a respeito do enriquecimento ambiental para grandes felinos em cativeiro, devido ao aumento da presença desses animais em zoológicos e centros de conservação, em consequência da perda do território natural e da predação humana. Assim, é necessário o estudo de técnicas que visam a melhoria da qualidade de vida por meio da 
Palavras-chave:

Ambiência

Bem-estar animal

Cativeiro

Felinos prática de estímulos físicos, sensoriais, cognitivos, sociais e alimentares que podem prevenir o estresse crônico e promover o desenvolvimento físico e psicológico do animal. Portanto, a prática de enriquecimento ambiental direcionada a animais em cativeiro permite a preservação de espécies em extinção enquanto promove comportamentos naturais, propiciando o seu bem-estar.

\section{ENVIRONMENTAL ENRICHMENT FOR BIG FELINES IN CAPTIVITY: LITERATURE REVIEW}

\begin{tabular}{l} 
ABSTRACT \\
$\begin{array}{l}\begin{array}{l}\text { Animal welfare is essential for maintaining the health and success } \\
\text { of animal conservation in captivity, that may suffer from atypical } \\
\text { and stereotyped habits when natural behaviors cannot be } \\
\text { expressed. That being so, the aim of this work was to carry out a } \\
\text { bibliographic review based on updated material on environmental } \\
\text { enrichment for large cats in captivity, due to the increased presence } \\
\text { of these animals in zoos and conservation centers, as a result of the } \\
\text { loss of natural territory and human predation. Consequently, it is } \\
\text { necessary to study techniques that aim to improve the quality of } \\
\text { life through the practice of physical, sensory, cognitive, social and } \\
\text { dietary stimuli that can prevent chronic stress and promote the } \\
\text { physical and psychological development of the animal. Therefore, } \\
\text { the practice of environmental enrichment aimed at animals in } \\
\text { captivity allows the preservation of endangered species while } \\
\text { promoting natural behaviors that contribute to the animals' well- } \\
\text { being. }\end{array} \\
\text { Ambience } \\
\text { Animal Welfare } \\
\text { Felids }\end{array}$ \\
\hline
\end{tabular}

\section{INTRODUÇÃO}

Os zoológicos, cativeiros, parques e centros de reabilitação deixaram de ser apenas um local para exposição de animais silvestres, com o intuito de gerar lazer para os seres humanos, e passaram a ser uma zona de preservação de espécies, educação ambiental e socialização da humanidade com a natureza (SANTOS, 2020). Contudo, nesses ambientes, em geral, os animais passaram a demonstrar comportamentos não habituais aos que eles teriam na selva, uma vez que eles não sentem determinadas necessidades, como a caça e a fuga (AIDAR, 2015). Dessa forma, para opor-se a esse comportamento atípico e, muitas vezes, estereotipado, as pessoas começaram a implementar nessas zonas o enriquecimento ambiental.

De acordo com Carpes (2015), o enriquecimento ambiental consiste na prática de técnicas dinâmicas no ambiente e no manejo diário dos animais, com o objetivo de permití- 
los expressar o seu comportamento selvagem habitual. Exemplos dessas práticas, descritas por Aidar (2015), são o enriquecimento ambiental cognitivo ou ocupacional, alimentar, sensorial, social e estrutural.

Os grandes felinos frequentemente são ameaçados pelos seres humanos por inúmeros motivos, perdendo, assim, recursos necessários à sobrevivência destes, como a alimentação, o habitat e, consequentemente, a redução da sua variabilidade genética (CUNHA, 2019). Portanto, é importante que haja a preservação dessas espécies, juntamente com seus comportamentos habituais. O ambiente enriquecido e implementado de equipamentos que favoreçam a vida de grandes felinos em cativeiro são mecanismos que diminuem reações atípicas ou agressivas. Além disso, mudanças de rotina estimulam o físico e o psicológico desses animais (RICCI et al., 2018).

Desta forma, objetivou-se neste trabalho realizar um levantamento bibliográfico acerca do enriquecimento ambiental para grandes felinos em cativeiro, abordando sobre as inúmeras técnicas que favorecem o comportamento mais próximo possível que esses animais teriam em um ambiente selvagem, pois a abordagem dessa temática é importância, não somente pela preservação das espécies, mas, também, para a manutenção do seu comportamento nativo.

\section{TÉCNICAS DE ENRIQUECIMENTO AMBIENTAL}

\subsection{Cognitivo ou ocupacional}

Segundo CARPES (2015), o enriquecimento ambiental do tipo cognitivo ou ocupacional refere-se a estruturas que estimulam o animal a utilizar as suas habilidades cognitivas. Exemplos dessa técnica são a utilização de caixas vazias ou com alimento e a utilização de meios de enriquecimento que estimulem forrageamento e a exibição de comportamentos exploratórios. Essas formas de manejo são de grande importância para simular o comportamento próprio do animal em vida livre (CARPES, 2015).

Camargo et al (2014), observaram que a utilização de mangueiras incentivam a ação de arranhar e morder, e, ainda, de comportamentos exploratórios quando oferecidas a um gato do mato. Segundo Carpes (2015), o oferecimento de peixes vivos é interessante, pois, além de animais como a onça e o tigre serem exímios nadadores e buscarem a água para se 
refrescarem, o estímulo ao ato da procura de alimento é uma ótima forma de enriquecimento ambiental.

A utilização de abóbora e melancia no chão do recinto ou em um lago, para que o animal gaste tempo tentando abri-las, é uma forma de aumentar o tempo em que o animal se mantém em atividade e exercitando suas habilidades cognitivas. Outra forma de enriquecimento ambiental é o treinamento dos animais com técnicas que estimulem a expressão de comportamentos desejados (CARPES, 2015).

\subsection{Alimentar}

A comida é um dos reforços mais eficientes ao se tratar de animais de cativeiro, onde os cativos podem aprender rapidamente diferentes formas de atividades relacionadas à entrega de comida (YOUNG; DE AZEVEDO; CIPRESTE, 2020).

O alimento também possui a capacidade de aumentar a frequência de atividades dos animais, como é o exemplo do estudo feito por Barros da Silva et al (2014), onde relataram que os animais que foram submetidos a diversos formas de enriquecimento ambiental e que, dentre eles, os enriquecimentos de caráter alimentar foram a caixa surpresa e o leite. Essa técnica obteve bons resultados no que se refere em diminuir o tempo de inatividade dos felinos em cativeiro.

Devido ao cativeiro naturalmente não oferecer variação no modo e do local onde o animal se alimenta, o enriquecimento ambiental alimentar procura dificultar o acesso ao alimento de maneira dinâmica, reproduzindo o que acontece em vida livre, onde os animais devem buscar o alimento, e podendo também oferecer alimentos diferentes do habitual (GANDRA, 2016).

\subsection{Sensorial}

Enriquecimentos sensoriais melhoram a saúde física, emocional e espiritual dos animais, sendo utilizados produtos como erva doce, camomila e óleos essenciais que, além de serem responsáveis pela redução do estresse em pessoas, possuem a capacidade de melhorar a investigação do ambiente por parte do animal, fazendo com que ele marque território esfregando-se nos odores e estimula, também, o seu sentido olfativo (RICCI et al, 2018). 
Novas experiências sensoriais, em termos de enriquecimento ambiental, são fornecidas com a finalidade de estimular as modalidades: visual, auditiva, olfativa e gustativa (esse último sendo considerado no enriquecimento alimentar), onde cada novo estímulo sensorial será registrado no cérebro de um animal e suas características aprendidas (YOUNG; DE AZEVEDO; CIPRESTE, 2020).

\subsection{Social}

Um ambiente social pode ser enriquecido com práticas que alterem a formação de grupos ou introduzem um novo coespecífico (se o animal estiver em isolamento) ou, ainda, promovem interações positivas entre os seres humanos e os animais. A mudança do ambiente social deve ser realizada através do conhecimento e da gestão que respeite as estruturas hierárquicas, levando em consideração os aspectos específicos das espécies.

A estimulação da sociabilidade em animais cativos vai além do contato intraespecífico, uma vez que a interação positiva com outras espécies, inclusive humanos, também pode ser enriquecedora. A interação entre as pessoas e os grandes felinos também é considerada como um enriquecimento social. Por fim, a qualidade e a quantidade de interações positivas entre animais e humanos são ambos relevantes ao bem-estar de felinos silvestres ou domésticos em cativeiro (DAMASCENO, 2018).

\subsection{Estrutural, ambiental ou físico}

O enriquecimento estrutural, ambiental ou físico possui como objetivo aumentar a complexidade da estrutura física do recinto em que o animal reside, o que pode ser feito com a adição de diversos elementos físicos, como a terra, a vegetação, a palha e as árvores, criando barreiras que proporcionam abrigo para os animais se esconderem e promovem um comportamento territorial e social. Além disso, a vegetação e o substrato também atraem fauna de flora, como os pássaros e os insetos, para dentro do recinto, o que oferece uma grande variedade de estímulos e permite que o ambiente seja semelhante com o habitat natural desses animais. Os materiais naturais também agregam ao enriquecimento estrutural, uma vez que providenciam proteção contra o calor excessivo e funcionam como isolante térmico em caso de baixas temperaturas (AIDAR, 2015).

Uma outra forma de criar um espaço rico com enriquecimento estrutural seria realizar uma mudança sistemática no ambiente, introduzindo objetos que permitam aos 
animais realizar movimentos e atividades, como escalar, saltar, rastejar, cavar, trotar, correr, entre outros, ou até trocando materiais do recinto, garantindo a manutenção de novidades dentro do recinto e tornando o espaço menos monótono (DAMASCENO, 2018). Um estudo feito com grandes felinos por Santos (2020), exemplifica a caixa de papelão em que o animal pode entrar (colocando parte ou todo seu corpo dentro da caixa), morder (aguçando a dentição) e arranhar (estimulando as garras desses felinos).

\section{IMPORTÂNCIA DO ENRIQUECIMENTO AMBIENTAL PARA GRANDES FELINOS CRIADOS EM CATIVEIRO}

Sabe-se que o ambiente cativo tem se tornado uma importante ferramenta para a conservação e manutenção dessas espécies, porém, tal espaço impõe aos animais selvagens condições muito diferentes daquelas encontradas em seu habitat natural. Comportamentos incomuns à espécie, tais como agressividade excessiva, estereotipias ou inatividade, são considerados resultados do cativeiro inadequado. Dessa forma, é de extrema importância que os recintos tenham ambientes enriquecidos e a equipe de técnicos e tratadores conheça o comportamento dos animais para que eles sejam mantidos em ótimas condições que apresentem um bom desenvolvimento físico e psicológico (RICCI, 2018).

Para construir um ambiente de cativeiro com um bom enriquecimento ambiental é de extrema importância que este seja baseado na biologia e no comportamento de cada espécie (CARPES, 2015). No caso dos grandes felinos, muitos são os benefícios que essa ferramenta traz para esses animais, como a redução de estresse crônico e estereotipias causado pelas limitações do cativeiro, pela dificuldade em apresentar um comportamento de caça e pela perturbação causada por outros animais e humanos. Além disso, cria um ambiente no qual o animal possa expressar seus comportamentos naturais, tais como forragear, investigar, caçar e esconder-se quando não quiser ser visto (AIDAR, 2015).

Por essa razão, é importante que os recintos tenham ambientes enriquecidos e a equipe de tratadores e técnicos conheça o comportamento desses animais para que felinos selvagens mantidos nessas condições apresentem um bom desenvolvimento físico e psicológico (RICCI, 2018). Ao realizar enriquecimentos ambientais é necessário que seja feito com responsabilidade, conhecimento, segurança e comprometimento dos profissionais responsáveis para manter o animal cativo saudável, neutralizar boa parte das diferenças entre o ambiente cativo e o natural e contribuir para a conservação de espécies. A confecção de 
um etograma é uma importante ferramenta para o começo de um programa de enriquecimento de sucesso, além de representar a qualificação e quantificação dos comportamentos exibidos pelos animais (CARPES, 2015).

\section{CONSIDERAÇÕES FINAIS}

Manter animais em cativeiro, embora antigamente tivesse objetivos puramente contemplativos, é hoje uma importante ferramenta para a conservação das espécies, especialmente com a crescente expansão da exploração ambiental e consequentemente destruição de habitats e ameaça de extinção a espécies. Dessa forma, é extrema importância que sejam desenvolvidas técnicas para elevação do bem-estar dos animais cativos, em detrimento aos efeitos adversos que essa condição pode causar. Assim, o enriquecimento ambiental pode atuar aumentando a diversidade ambiental, diminuindo a previsibilidade $\mathrm{e}$ elevando a expressão de comportamentos adequados e naturais, o que eleva, ainda, o potencial educativo e sensibilizador nos cativeiros e zoológicos. É crucial, no entanto, que sua aplicação siga critérios e seja realizada com acompanhamento comportamental por profissionais capacitados.

\section{REFERÊNCIAS}

AIDAR, M. F. C. Enriquecimento ambiental na reintrodução de felinos na natureza (Mammalia: Carnivora: Felidae). Trabalho de Conclusão de Curso (Bacharel em Ciências Biológicas) - Universidade Presbiteriana Mackenzie, São Paulo, 2015.

BARROS DA SILVA, T. B. et al. Enriquecimento ambiental para felinos em cativeiro. Atas de Saúde Ambiental - ASA, São Paulo, v. 2, n. 3, p. 47-52, set/dez. 2014.

CAMARGO, J. R. P.; NASCIMENTO, E. L.; SANTOSPREZOTO, H. H. Técnicas de Enriquecimento Ambiental de Gato do Mato Leopardus Guttulus (Schreber, 1775), em 66 Cativeiro: um Estudo de Caso. CES Revista, Juiz de Fora, v. 28, n. 1, p.169-179, 2014.

CARPES, A. Z. Ferramentas para Aplicação de Enriquecimento Ambiental para Felinos Cativos. Trabalho de Conclusão de Curso (Bacharel em Ciências Biológicas) Universidade Federal de Santa Catarina, Florianópolis, 2015.

CUNHA, P. F. Técnicas de enriquecimento ambiental aplicadas para Leopardus pardalis (Linnaeus, 1758) (Carnivora, Felidae) em cativeiro. Trabalho de Conclusão de 
Curso (Bacharel em Ciências Biológicas) - Universidade Federal Uberlândia, Uberlândia, 2019.

DAMASCENO, J. Enriquecimento ambiental para felinos em cativeiro: classificação de técnicas, desafios e futuras direções. Revista Brasileira de Zoociências, Minas Gerais, v. 19, n. 2, p. 164-184, jun-jul 2018.

GANDRA, G. L. Enriquecimento ambiental como ferramenta para a promoção de bem-estar em Panthera onca (Linnaeus, 1758), em cativeiro. 2016. 44 f. Trabalho de Conclusão de Curso (Bacharelado)- Departamento de Biologia, Universidade Federal do Ceará, Fortaleza, 2016.

RICCI, G. D. et al. Efeito de diferentes técnicas de enriquecimento ambiental em cativeiro de onças suçuaranas (Puma concolor). Ciência Animal Brasileira, v. 19, n. 0, 2018.

SANTOS, C. C. C. dos. Aplicação de enriquecimento ambiental para pequenos felinos cativos no Parque Arruda Câmara, A Bica, em João Pessoa/PB. Trabalho de Conclusão de Curso (Bacharel em Zootecnia) - Universidade Federal da Paraíba, Areia, 2020.

YOUNG, R. J.; DE AZEVEDO, C. S.; CIPRESTE, C. F. Environmental Enrichment. In: MELFI, V. A.; DOREY, N. R.; WARD, S. J. (Eds.). Zoo Animal Learning and Training. John Wiley \& Sons Ltd., 2020. p. 101-118. 


\section{ORDEM DE PARIÇÃO E EFICIÊNCIA PLACENTÁRIA EM FÊMEAS SUIINAS CRIADAS NO SEMIÁRIDO}

\section{Amanda Medeiros Araújo de Oliveira}

Universidade Federal do Ceará, Departamento de Zootecnia, Fortaleza - Ceará http://lattes.cnpq.br/6537597186282951

\section{Lucas Paz Martins}

Universidade Estadual do Ceará, Faculdade de Veterinária, Fortaleza - Ceará http://lattes.cnpq.br/2982214663044540

\section{Atirson Bruno Martins de Sousa}

Universidade Estadual do Ceará, Faculdade de Veterinária, Fortaleza - Ceará http://lattes.cnpq.br/9617806332597532

\section{Caio Vitor Oliveira Silva}

Universidade Estadual do Ceará, Faculdade de Veterinária, Fortaleza - Ceará http://lattes.cnpq.br/9888210306570180

\section{Deborah Marrocos Sampaio Vasconcelos}

Universidade Estadual do Ceará, Faculdade de Veterinária, Fortaleza - Ceará http://lattes.cnpq.br/0963785185263043

\section{Cibelle Mara Pereira de Freitas}

Universidade Estadual do Ceará, Faculdade de Veterinária, Fortaleza - Ceará $\underline{\text { http://lattes.cnpq.br/5941435633494996 }}$

\section{Érica Maria Sousa de Queiroz Campos}

Universidade Estadual do Ceará, Faculdade de Veterinária, Fortaleza - Ceará http://lattes.cnpq.br/6341986339492272

\section{Tiago Silva Andrade}

Universidade Estadual do Ceará, Faculdade de Veterinária, Fortaleza - Ceará http://lattes.cnpq.br/7161796048983496

\section{José Nailton Bezerra Evangelista}

Universidade Estadual do Ceará, Faculdade de Veterinária, Fortaleza - Ceará http://lattes.cnpq.br/3648513271604631

\section{Ênio Campos da Silva}

Universidade Estadual do Ceará, Faculdade de Veterinária, Fortaleza - Ceará http://lattes.cnpq.br/6829076136051055

\section{Lina Raquel Santos Araújo}

Universidade Estadual do Ceará, Faculdade de Veterinária, Fortaleza - Ceará http://lattes.cnpq.br/7591378438576586 
Informações sobre o

artigo:

Recebido em:

$30 / 08 / 2020$

Aceite em:

31/08/2020

Data de publicação:

05/10/2020

Palavras-chave:

\section{Gestação}

Peso do leitão

Suinocultura

\section{RESUMO}

Durante a gestação, vários fatores relacionados ao ambiente uterino podem influenciar o desenvolvimento feto-placentário. A distribuição vascular uterina, o fluxo sanguíneo nas diferentes regiões do útero e até mesmo a localização fetal ao longo do corno uterino são alguns exemplos de características ligadas à sobrevivência e ao crescimento dos conceptos em espécies hiperprolíficas. O objetivo do presente trabalho foi avaliar a influência da ordem de parição sobre a eficiência placentária de fêmeas suínas. Foram utilizadas 40 fêmeas que foram divididas igualmente em quatro grupos, de acordo com sua ordem de parição $\left(1^{a}, 2^{a}, 3^{a}\right.$ e $\left.4^{a}\right)$. As fêmeas foram acompanhadas durante todo o parto para obtenção dos dados do parto e dos pesos da placenta e da leitegada, o que possibilitou realizar o cálculo da eficiência placentária de cada animal. Os dados foram submetidos à análise de variância (ANOVA), as correlações foram feitas pelo teste de Pearson e as médias comparadas pelo Teste de Tukey utilizando o Programa Estatístico R, com probabilidade de 5\%. Verificou-se alta correlação positiva $(\mathrm{P}<0,001)$ entre número total de leitões (NTL) e o peso da leitegada, e moderada correlação negativa entre peso da placenta e eficiência placentária. As variáveis número total de leitões, peso da placenta e eficiência placentária não foram influenciadas pela ordem de parição $(\mathrm{P}>0,05)$. Maior período gestacional foi registrado em fêmeas de primeiro parto em relação as de $3^{\circ}$ e $4^{\circ}$ partos $(\mathrm{P}<0,01)$. Enquanto maior peso da leitegada foi observado em matrizes de terceiro parto em relação as de segundo parto apenas $(\mathrm{P}<0,05)$. Constatou-se que a ordem de parto da fêmea suína não influencia na eficiência placentária, embora possa influenciar outras variáveis como a duração de gestação e o peso da leitegada.

\section{PARTURITION ORDER AND PLACENTAL EFFICIENCY IN SWINE FEMALE CREATED IN SEMIARID}

\section{ABSTRACT}

During pregnancy, several factors related to the uterine environment can influence fetal placental development. The uterine vascular distribution, the blood flow in the different regions of the uterus and even the fetal location along the uterine horn are some examples of characteristics linked to the survival and growth of the fetuses in hyperprolific species. The objective of this study was to evaluate the influence of lactation numbers on the placental efficiency of sows. Forty females were used and divided equally into four groups, according to their calving order (1 st, 2nd, 3rd and 4th). The females were monitored throughout the birth to obtain the birth data and the placenta and litter weights, which made it

Keywords:

\section{Gestation}

Pig farming

Piglet weight 
possible to calculate the placental efficiency of each animal. The data were submitted to analysis of variance (ANOVA), the correlations were made by the Pearson test and the means compared by the Tukey test using the R statistical program, with a $5 \%$ probability. There was a high positive correlation $(\mathrm{P}<0.001)$ between the total number of piglets (NTL) and the weight of the litter, and a moderate negative correlation between weight of the placenta and placental efficiency. The variables total number of piglets, placental weight and placental efficiency were not influenced by the calving order ( $\mathrm{P}>0.05$ ). Longer gestational period was recorded in females at first farrowing compared to those from 3rd and 4th births $(\mathrm{P}<0.01)$. While greater weight of the litter was observed in third farrowing sows in relation to those of second parturition only $(\mathrm{P}<0.05)$. It was found that the calving order of the swine does not influence placental efficiency, although it can influence other variables such as gestation duration and litter weight.

\section{INTRODUÇÃO}

No Brasil, o sucesso da suinocultura moderna está relacionado, em grande parte, à eficiência no desempenho reprodutivo das matrizes. Através da genética, foi possível selecionar animais com características desejáveis ao aumento da produção, tais como, aumento da taxa de crescimento, eficiência alimentar e habilidade materna (ASSOCIAÇÃO BRASILEIRA DE CRIADORES DE SUÍNOS, 2014). Da mesma forma, as matrizes suínas foram selecionadas para o aumento da prolificidade, apresentando taxas de ovulação cada vez maiores e consequentemente, leitegadas maiores, tornando-se as chamadas fêmeas hiperprolíficas (ALMEIDA, 2009; ZOTTI et al., 2017).

No Brasil, os resultados desta seleção genética podem ser percebidos pelo aumento do número de leitões nascidos por leitegada, cuja média em 1992 era de 10,9 e em 2017, passou a ser de 12,61 (PANZARDI, 2010; ASSOCIAÇÃO BRASILEIRA DE CRIADORES DE SUÍNOS, 2017). Em consequência, o grande número de leitões levou a diminuição do peso ao nascimento e aumento da variabilidade de peso dentro das leitegadas (FERRARI, 2013; ZOT'TI et al., 2017). Fator que pode ser explicado pelo menor espaço uterino e viabilidade placentária disponíveis por leitão, levando-os a competirem por nutrientes e oxigênio (ALMEIDA, 2009).

Durante a gestação, vários fatores relacionados ao ambiente uterino podem influenciar o desenvolvimento feto-placentário. A distribuição vascular uterina, o fluxo sanguíneo nas diferentes regiões do útero e até mesmo a localização fetal ao longo do corno 
uterino são alguns exemplos de características ligadas à sobrevivência e ao crescimento dos conceptos em espécies hiperprolíficas. Com a superlotação uterina observada em suínos, essas características podem estar relacionadas à variação no desenvolvimento dos conceptos (BETARELLI, 2013).

A placenta, por ser o órgão responsável pela oxigenação e nutrição dos embriões, tem influência direta no peso ao nascimento dos leitões, pois seu desenvolvimento, principalmente vascular, é o que garante a boa disponibilidade de metabólitos aos fetos (PRAZERES, 2015). Além disso, o aporte sanguíneo é um indicador de eficiência placentária e poderia permitir que placentas pequenas fossem capazes de nutrir conceptos adequadamente, caso este aporte fosse elevado (BETARELLI, 2013). Dessa forma, neste trabalho buscou-se avaliar a influência da ordem de parição sobre a eficiência placentária.

\section{MATERIAL E MÉTODOS}

O experimento foi realizado na Unidade Produtora de Leitões de uma granja comercial localizada no município de Maranguape-CE. Foram utilizadas 40 fêmeas da linhagem comercial Topigs $20^{\circledR}$ da empresa de material genético TOPIGS NORSVIN ${ }^{\circledR}$, com diferentes pesos e idades, distribuídas igualmente nas diferentes ordens de parição conforme apresentado na tabela 1 .

Tabela 1. Distribuição do número de fêmeas por ordem de parição.

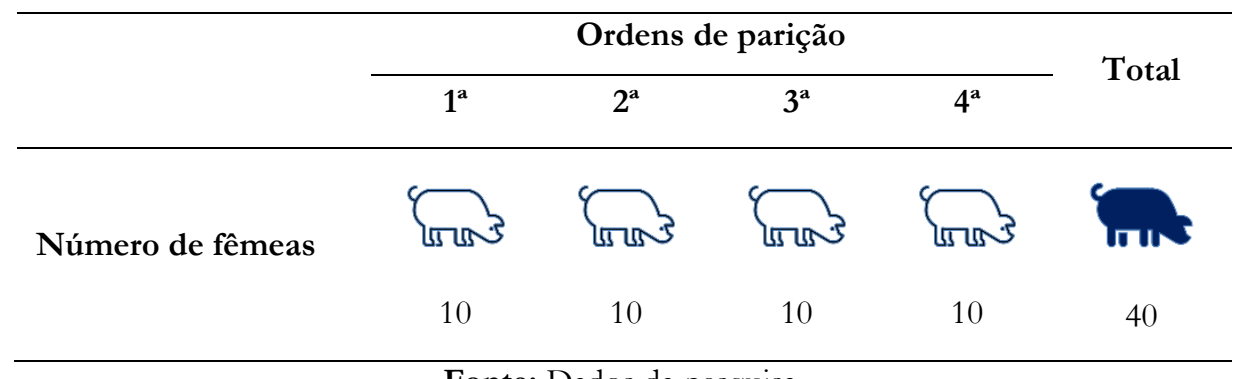

Fonte: Dados da pesquisa.

As fêmeas eram alojadas em gaiolas de gestação, cerca de 4 dias antes da data provável do parto eram transferidas para as baias de maternidade que possuíam celas parideiras, sistema de ventilação individual para fêmeas lactantes e cortinas reguláveis nas laterais dos galpões. Durante os dois primeiros terços do período gestacional, até 85-90 dias de gestação, as fêmeas era alimentadas diariamente com 2,0 kg de ração gestação. No último terço de gestação passaram a receber entre 2,0 a 3,0 kg ao dia de ração pré-lactação com 
aumentos gradativos conforme avanço da gestação. E após o parto eram alimentadas com ração do tipo lactação, cujo arraçoamento na primeira semana era acrescido de $1 \mathrm{~kg}$ ao dia até atingir a quantidade máxima de ingestão diária, que considerava a quantidade de leitões lactentes. As matrizes recebiam $2 \mathrm{~kg}$ para mantença mais $0,5 \mathrm{~kg}$ por cada leitão lactente, $\mathrm{o}$ total de ração calculado era fracionado em quatro tratos diários, as rações foram formuladas para atender os níveis nutricionais de cada fase conforme consta no manual da linhagem (TOPIGS NORSVIN, 2018). O fornecimento de água era à vontade em ambas as fases, na gestação a água era disponibilizadas em bebedouros tipo calha e na maternidade em bebedouros tipo chupeta com vazão adequada para a fase.

As fêmeas foram acompanhadas durante todo o parto para obtenção dos dados da leitegada e dos pesos da placenta e da leitegada, o que possibilitou realizar o cálculo da eficiência placentária de cada animal. Esta foi calculada pela razão entre o peso total da leitegada (soma dos pesos dos leitões nascidos vivos, natimortos, mumificados e macerados) e o peso da placenta (Figura 1). Como todas as fêmeas foram identificadas, isso permitiu correlacionar a eficiência placentária de cada fêmea com sua ordem de parto.

Figura 1. Fórmula utilizada para calcular a eficiência placentária no estudo.

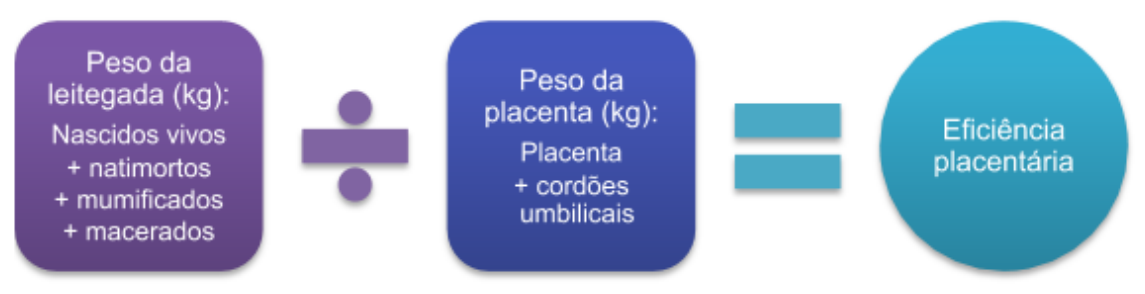

Todos os leitões foram pesados individualmente imediatamente após o parto. As placentas foram coletadas imediatamente após sua expulsão juntamente com o cordão umbilical e foram pesadas em balança de precisão. Essas pesagens aconteceram durante todo o processo de parto para evitar viés decorrente da evaporação de líquidos caso o material fosse guardado para posterior pesagem. Ao fim foram compilados os dados de período de gestação, número total de leitões nascidos, peso de placenta, eficiência placentária e peso total da leitegada.

Avaliou-se as correlações entre as variáveis analisadas pelo teste de Pearson, os dados foram submetidos à análise de variância (ANOVA) e as médias comparadas pelo Teste de Tukey e as utilizando o Programa Estatístico R, com probabilidade de 5\%. 


\section{RESULTADOS E DISCUSSÃO}

Verificou-se alta correlação positiva $(\mathrm{P}<0,001)$ entre número total de leitões (NTL) e o peso da leitegada e moderada correlação negativa entre peso da placenta e eficiência placentária (Tabela 2). As demais correlações identificadas, embora significativas, foram fracas $(r<0,5)$.

Tabela 2. Coeficientes de correlação entre as variáveis estudadas.

\begin{tabular}{llllll}
\hline & $\begin{array}{l}\text { Duração } \\
\text { gestação }\end{array}$ & da & $\begin{array}{l}\text { Número } \\
\text { Leitões }\end{array}$ & $\begin{array}{c}\text { Total } \\
\text { Placenta }\end{array}$ & $\begin{array}{l}\text { Eficiência } \\
\text { Placenta }\end{array}$ \\
\hline $\begin{array}{l}\text { Número } \\
\text { Leitões }\end{array}$ & $-0,073$ & & & \\
$\begin{array}{l}\text { Peso Placenta } \\
\text { Eficiência Placenta }\end{array}$ & $0,0,097$ & $0,401^{*}$ & $-0,633^{* *}$ & \\
Peso total da leitegada & 0,026 & $0,342^{*}$ & $0,340^{*}$ & $0,322^{*}$ \\
\hline
\end{tabular}

Correlações significativas pelo Teste de Pearson: $*<0,05 ; * *<0,0001$

A ordem de parição de matrizes suínas influenciou as variáveis duração de gestação e peso total da leitegada $(\mathrm{P}<0,05)$, no entanto as variáveis número total de leitões, peso da placenta e eficiência placentária não apresentaram diferenças estatísticas nas diferentes ordens de parto (Tabela 3). Maior período gestacional foi registrado em fêmeas de primeiro parto em relação as de $3^{\circ}$ e $4^{\circ}$ partos $(\mathrm{P}<0,01)$. Enquanto maior peso da leitegada foi observado em matrizes de terceiro parto em relação as de segundo parto apenas $(\mathrm{P}<0,05)$.

Tabela 3. Duração da gestação, número total de leitões nascidos, peso da placenta, eficiência placentária e

\begin{tabular}{|c|c|c|c|c|c|}
\hline $\begin{array}{l}\text { Ordem } \\
\text { de Parto }\end{array}$ & $\begin{array}{c}\text { Duração da } \\
\text { gestação }\end{array}$ & $\begin{array}{c}\text { Número Total } \\
\text { Leitões }\end{array}$ & $\begin{array}{c}\text { Peso } \\
\text { Placenta } \\
\end{array}$ & $\begin{array}{c}\text { Eficiência } \\
\text { Placenta }\end{array}$ & $\begin{array}{c}\text { Peso total da } \\
\text { Leitegada }\end{array}$ \\
\hline 1 & $115,4 \mathrm{a}$ & 12,1 & 2,9 & 6,1 & $19,6 a b$ \\
\hline 2 & $114,6 \mathrm{ab}$ & 13,1 & 3,3 & 5,5 & $17,3 \mathrm{~b}$ \\
\hline 3 & $114,1 \mathrm{~b}$ & 14,8 & 3,5 & 6,1 & $20,4 \mathrm{a}$ \\
\hline 4 & $114,0 \mathrm{~b}$ & 14,7 & 3,3 & 5,9 & $18,9 \mathrm{ab}$ \\
\hline Média & 114,5 & 13,7 & 3,3 & 5,9 & 19,1 \\
\hline $\begin{array}{l}\text { Desvio } \\
\text { médio }\end{array}$ & 0,8 & 2,4 & 0,7 & 1,3 & 2,5 \\
\hline $\mathrm{CV}(\%)$ & 0,7 & 17,5 & 21,9 & 21,6 & 13,1 \\
\hline Valor de $\mathrm{P}$ & 0,0065 & 0,1600 & 0,5290 & 0,8530 & 0,0165 \\
\hline
\end{tabular}
Letras distintas nas colunas diferem pelo teste de Tukey, $\mathrm{p}<0,05$.

A eficiência placentária (EP) é definida como o peso fetal dividido pelo peso placentário descrevendo a quantidade de tecido fetal que pode ser produzido por grama de 
placenta (CHRISTENSON et al., 1987). A EP pode diferir entre raças, o Meishan, raça altamente prolifica de origem chinesa, apresenta alta EP, apresentando placentas pequenas e altamente vascularizadas, enquanto Yorkshires mostram baixa EP, com placentas maiores e menos vascularizadas (WILSON et al., 1998). A variação placentária também é encontrada entre indivíduos e até entre ninhadas, no entanto, conforme este estudo a ordem de parição pareceu não influenciar este parâmetro. Neste sentido, é comum encontrar placentas com diferentes tamanhos que produzem leitões com tamanhos semelhantes. A eficiência placentária pode variar muito, resultando em leitões com tamanhos semelhantes associados à placenta com peso diferente, com até $50 \%$ de diferença de peso. No entanto, as condições que permitem que uma placenta de menor peso produza leitegada de tamanho semelhante à de maior peso ainda são desconhecidas (WILSON et al., 1998).

Estudos sobre aumento da taxa de ovulação, da capacidade uterina e do comprimento uterino foram realizados com o objetivo de aumentar o tamanho da leitegada, no entanto não resultaram em aumento da leitegada, pois a eficiência placentária não havia sido considerada (FENTON et al., 1972; CHRISTENSON et al., 1987; JOHNSON et al. 1999). A eficiência placentária é um fator importante para o tamanho da leitegada (KROMBEEN, 2017). A placenta desempenha um papel vital no desenvolvimento do leitão. As funções placentárias incluem trocas de nutrientes e gases, metabolismo e produção de hormônios (BAUER et al., 1998).

Krombeen (2017) observaram que placentas não apresentaram diferenças entre EPs quanto às concentrações de cortisol e glicose, sugerindo que placentas de alta EP têm outros meios que permitem o transporte de quantidades semelhantes de nutrientes e hormônios, apesar do tamanho reduzido. Segundo Vallet e Freking (2007), a eficiência placentária foi maior em leitegadas menores, indicando que talvez a relação entre o peso fetal e o peso da placenta não seja o melhor indicador de EP. Esses autores sugeriram que as placentas de fetos menores foram mais eficientes porque a placenta compensou a diminuição. Já Vernunft et al. (2018) observaram forte correlação do peso placentário com o tamanho da leitegada, discordando dos achados do presente estudo. Neste sentido, a eficiência placentária parece não ser afetada pela ordem de parição da fêmea, existindo outras fontes de variação, como a obesidade materna (LI et al., 2019), que podem influenciar os resultados. 


\section{CONCLUSÃO}

A ordem de parto da fêmea suína não influencia na eficiência placentária embora possa influenciar outras variáveis como a duração de gestação e o peso da leitegada.

\section{REFERÊNCIAS}

ALMEIDA, F. R. C. L. Influência da nutrição da fêmea sobre a qualidade do leitão ao nascer. Acta Scientiae Veterinarie, v. 37, n. Supl 1, p. 31-33, 2009.

ASSOCIAÇÃO BRASILEIRA DE CRIADORES DE SUÍNOS. Relatório do serviço de registro genealógico de suínos, 2014. Estrela - RS: [s.n.].

ASSOCIAÇÃO BRASILEIRA DE CRIADORES DE SUÍNOS. Relatório do serviço de registro genealógico de suínos, 2017. Estrela - RS: [s.n.].

BAUER, M. K., J. E. et al. Fetal growth and placental function. Molecular and Cellular Endocrinology, v.140, n.1-2, p.115-120, 1998.

BETARELLI, R. P. Estudo da vascularização uterina em primíparas suínas e sua relação com o desenvolvimento fetal e placentário. Lavras, 2013, 84 p. Dissertação. Mestrado em Ciências Veterinárias.

CHRISTENSON, R. K.; LEYMASTER, K.A.; YOUNG, L.D. Justification of unilateral hysterectomy-ovariectomy as a model to evaluate uterine capacity in swine. Journal of Animal Science, v.65, n.3, p.738-744, 1987.

FENTON, F. R. et al. Stage of gestation when uterine capacity limits embryo survival in gilts. Journal of Animal Science, v.35, n.2, p.383-388, 1972.

FERRARI, C. V. Efeito do peso ao nascer e ingestão de colostro na mortalidade e desempenho de leitões após a uniformização em fêmeas de diferentes ordens de parição. Universidade Federal Do Rio Grande Do Sul, p. 52, 2013.

JOHNSON, R. K.; NIELSEN, M.K.; CASEY, D.S. Responses in ovulation rate, embryonal survival, and litter traits in swine to 14 generations of selection to increase litter size. Journal of Animal Science, v.77, n.3, p.541-557, 1999.

KROMBEEN, S.K. Neonatal Growth Measurements, Umbilical Concentrations, and Differential Gene Expression in the Placenta of Swine in Relation to Placental Efficiency. 2017. All Theses. 2789. Disponível em: https://tigerprints.clemson.edu/all theses/2789 Acesso em 25 ago.2020.

LI, J.-W. et al. The Effects of Maternal Obesity on Porcine Placental Efficiency and Proteome. Animals, v.9, n.8, p.1-18, 2019. 
PANZARDI, A. "Impactos do peso da fêmea no último mês de gestação sobre a ocorrência de leitegadas desuniformes e influência dos parâmetros fisiológicos do leitão ao nascimento sobre seu desempenho pós-natal". [s.l.] Universidade Federal do Rio Grande do Sul, 2010.

PRAZERES, C. D. Efeito da classe de tamanho de leitegada sobre a variação do peso ao nascer e ao desmame em leitões da raça landrace. [s.l.] Universidade Federal de Santa Catarina, 2015.

TOPIGS NORSVIN. Manual de Fêmeas Topigs Norsvin. 2018. 73p. Disponível em: $<$ https://topigsnorsvin.com.br/download-pt-br/manuais-tecnicos-topigs-norsvin/> Acesso em 30 jun. 2018.

VALLET, J. L.; FREKING, B.A. Differences in placental structure during gestation associated with large and small pig fetuses. Journal of Animal Science, v.85, n.12, p.3267$3275,2007$.

VERNUNFT A., MAASS M., BRÜSSOW K.P. Características placentárias das porcas alemãs landrace e suas relações com diferentes parâmetros de fertilidade . Tcheco Journal of Animal Science, v.63, p.339-346, 2018.

WILSON, M. E. et al. Development of meishan and yorkshire littermate conceptuses in either a meishan or yorkshire uterine environment to day 90 of gestation and to term. Biology of Reproduction, v.58, n.4, p.905-910, 1998.

ZOTTI, E. et al. Impact of piglet birthweight and sow parity on mortality rates, growth performance, and carcass traits in pigs. Revista Brasileira de Zootecnia, v. 46, n. 11, p. 856-862, 2017. 


\section{PESTE SUÍNA AFRICANA: BIOSSEGURIDADE, A MELHOR ESTRATÉGIA}

\section{Pamela Lorenzi Meimberg}

Médica Veterinária; graduada em Medicina Veterinária no Centro Universitário União de Ensino do Sudoeste do Paraná.

\section{Lina Raquel Santos Araújo}

Médica Veterinária; Mestre, em Ciências Veterinárias pela Universidade Estadual do Ceará, Doutora em Zootecnia pela Universidade Federal do Ceará.

http://lattes.cnpq.br/7591378438576586

\section{Pedro Filipe de Souza Teles}

Médico Veterinário; Mestre em Zootecnia pela Universidade do Estado de Santa Catarina. http://lattes.cnpq.br/9053008093218222

\begin{tabular}{|c|c|}
\hline $\begin{array}{l}\text { Informações sobre o } \\
\text { artigo: }\end{array}$ & RESUMO \\
\hline $\begin{array}{l}\text { Recebido em: } \\
\text { 19/07/2020 } \\
\text { Aceite em: } \\
\text { 31/07/2020 } \\
\text { Data de publicação: } \\
\text { 05/10/2020 } \\
\text { Palavras-chave: } \\
\text { Enfermidade } \\
\text { Sanidade } \\
\text { Segurança alimentar } \\
\text { Suídeos }\end{array}$ & $\begin{array}{l}\text { A peste suína africana (PSA) é uma enfermidade altamente } \\
\text { contagiosa causada por um vírus DNA da família Asfaviridae que } \\
\text { atinge suídeos domésticos e asselvajados. As altas taxas de } \\
\text { mortalidade e morbidade aliadas a ausência de cura e de vacinas } \\
\text { fazem com que esta enfermidade resulte em grandes prejuízos } \\
\text { socioeconômicos, sendo seus efeitos sentidos não apenas na região } \\
\text { afetada, mas sim mundialmente. Este estudo tem como objetivo } \\
\text { revisar a PSA e ressaltar a importância da prática de biosseguridade, } \\
\text { sendo esta, a melhor estratégia e o melhor investimento para } \\
\text { manter a unidade produtiva segura da entrada e propagação deste } \\
\text { e de outros patógenos indesejados. }\end{array}$ \\
\hline $\begin{array}{l}\text { Keywords: } \\
\text { Disease } \\
\text { Food security } \\
\text { Health } \\
\text { Swine }\end{array}$ & $\begin{array}{l}\text { PARTURITION ORDER AND PLACENTAL } \\
\text { EFFICIENCY IN SWINE FEMALE CREATED IN } \\
\text { SEMIARID } \\
\text { ABSTRACT } \\
\text { African swine fever (PSA) is a highly contagious disease caused by } \\
\text { a family DNA virus Asfaviridae that affects domestic swine and } \\
\text { wild swine. The high rates of mortality and morbidity combined } \\
\text { with the lack of cure and vaccines make this disease result in great } \\
\text { socioeconomic losses, its effects being felt not only in the affected } \\
\text { region, but worldwide. This one study aims to review the PSA and } \\
\text { emphasize the importance of the practice of biosecurity, this being } \\
\text { the best strategy and the best investment to maintain the safe } \\
\text { productive unit for the entry and spread of this and other } \\
\text { pathogens unwanted. }\end{array}$ \\
\hline
\end{tabular}




\section{INTRODUÇÃO}

Em meados de setembro de 2018, houve um verdadeiro colapso no mercado mundial de carnes, isso porque na Ásia foi diagnosticada em criações de subsistência, a presença do vírus da peste suína africana (VPSA). A peste suína africana (PSA) é uma enfermidade altamente contagiosa, e possui uma alta taxa de mortalidade. Sem cura, tratamento e nem vacinas para seu controle, o abate sanitário dos animais é uma das medidas para evitar a disseminação desta doença (CARDOSO, 2019). Os países do continente asiático, europeu e africano foram acometidos por este surto, acumulando desde o final de 2018 até início de 2020 aproximadamente 4.6 milhões de suídeos mortos ou sacrificados devido a PSA, sendo o continente asiático o mais afetado (OIE, 2020a). Segundo análise de Miranda et al. (2020) somente na China já havia sido registrado, até outubro de 2019, o abate de 1,19 milhão de cabeças de suínos.

Diante desse cenário de crise na Ásia, houve um reflexo mundial no mercado de carnes, para poder suprir a demanda deixada pela China. Isso porque a China é o país que possui o maior rebanho de suínos, com aproximadamente 428,1 milhões de animais registrados em 2019 e também é o maior consumidor de carne suína, registrando em 2018 um consumo de 55.398 milhões de toneladas (CARDOSO, 2019).

O Brasil, que é o quarto maior produtor de carne suína do mundo, ficando atrás apenas da China, União Européia e Estados Unidos (ABPA, 2019), foi um dos países que absorveu essa demanda deixada pela China, como consequência o comércio internacional de carnes bovina, suína e de frango vem crescendo no país, o Ministério da Agricultura, Pecuária e Abastecimento (MAPA) estima, para 2020, que a produção nacional de carnes suprirá $44,5 \%$ do mercado mundial, sendo 48,1\% da carne de frango e $14,2 \%$ da carne suína nas exportações mundiais (BRASIL, 2019b).

A condição sanitária do país é a principal referência para o comércio seguro de animais e seus produtos entre os países. A Organização Mundial de Saúde Animal (OIE) destaca a PSA e a peste suína clássica (PSC) como as doenças mais relevantes para o comércio internacional de produtos de origem suína (BRASIL, 2019a). Atualmente o Brasil é considerado um país livre da PSA, a última ocorrência foi registrada em 1981 (BRASIL, 2018), e é dividido em zona livre e zona não livre de PSC (BRASIL, 2019a).

Com toda essa demanda de produção no Brasil aliada com as exigências sanitárias, as práticas de biosseguridade devem ser priorizadas para proteger a unidade produtiva desta e de outras enfermidades que podem trazer grandes prejuízos para o país, como cita Gava et 
al. (2018a) que estimou um prejuízo de aproximadamente 5,5 bilhões de dólares apenas no Brasil, caso a PSA fosse diagnosticada no país.

Diante disto vemos que a biosseguridade é uma prática indispensável na unidade produtiva, sendo esta a principal estratégia de medida preventiva. O presente artigo tem como objetivo revisar as principais características da PSA e salientar como práticas simples de biosseguridade protegem não só a sanidade dos animais de uma unidade produtiva, mas sim toda uma cadeia produtiva e o mercado nacional.

\section{O QUE É A PESTE SUINA AFRICANA?}

É uma enfermidade altamente contagiosa causada por um vírus DNA da família Asfaviridae que atinge suídeos domésticos e asselvajados (javalis e cruzamentos com suínos domésticos). Os sinais clínicos e a taxa de mortalidade variam de acordo com a virulência do vírus e o tipo de suíno atingido. Se a virulência da cepa do vírus é alta os sinais apresentados são febre alta, hemorragias na pele (vermelhidão da pele nos ouvidos, abdômen e pernas), sinais reprodutivos como abortos e uma alta taxa de mortalidade, podendo chegar em até 100\%, já as cepas menos virulentas provocam sinais crônicos, como perda de peso, febre intermitente, sinais respiratórios, úlceras crônicas da pele e artrite, fazendo do animal um portador do vírus e potencial transmissor do mesmo (OIE, 2018b). A PSA está listada no Código de Saúde Animal Terrestre da OIE (OIE, 2020b) e é uma doença de notificação imediata ao serviço veterinário oficial em caso de suspeita ou de diagnóstico laboratorial como preconiza a Instrução Normativa no 50 de 2013 (BRASIL, 2013).

\section{BREVE HISTÓRICO}

A PSA tem sido observada desde o início do século 20, no sul e leste africanos (CARDOSO, 2019). No Brasil, o primeiro surto da PSA foi identificado no estado do Rio de Janeiro, no município de Paracambi, em 1978 (LYRA et al.,1986 apud LYRA; FREITAS, 2015). O surto se deu pelo fornecimento a suínos de alimentos contendo resíduos de carne suína contaminada com o vírus, de um voo proveniente de Portugal (CARDOSO, 2019).

A partir desse fato o Brasil adotou medidas de emergência para a erradicação da PSA através do Decreto nº 81.798/78 (BRASIL, 1978) que mobilizou vários órgãos como o 
Ministério da Saúde, do Interior, da Fazenda, dos Transportes e da Justiça e os governos estaduais e municipais. Dentre as medidas estavam o controle do trânsito de pessoas, animais ou veículos, também o sacrifício sanitário dos animais doentes e dos que haviam tido contato com os animais doentes, cremação dos animais mortos, desinfecção e destruição das instalações não conformes, medidas essas recomendadas pela OIE (LYRA, 2006). Em 1984 o Brasil foi declarado livre da PSA (BRASIL, 2019a).

Até 2015 a PSA estava distribuída nos continentes africano e europeu, sendo em sua maioria focos limitados a uma ou mais zonas (Figura 1) e desde 2016 foi identificado um aumento significativo na quantidade de surtos, $24 \%$ dos países e territórios declarantes (48/200) relataram a presença da doença. Em 2017 e 2018 o VPSA foi detectado em suínos de subsistência na Romênia e na China, respectivamente, e em javalis na Bélgica em 2018 (a última ocorrência havia sido em 1985), a fonte comum de infecção foram alimentos de origem suína não cozidos e contaminados com o vírus que foram ofertados aos animais. Atualmente a PSA encontra-se distribuída nas regiões da África, Europa e Ásia, sem ocorrência na Oceania e foi erradicada nas Américas nos anos 90 conforme Figura 2 (OIE, 2015, 2018a, 2019b; CARDOSO, 2019).

Figura 1. Distribuição geográfica da PSA em 2015 (OIE, 2015).

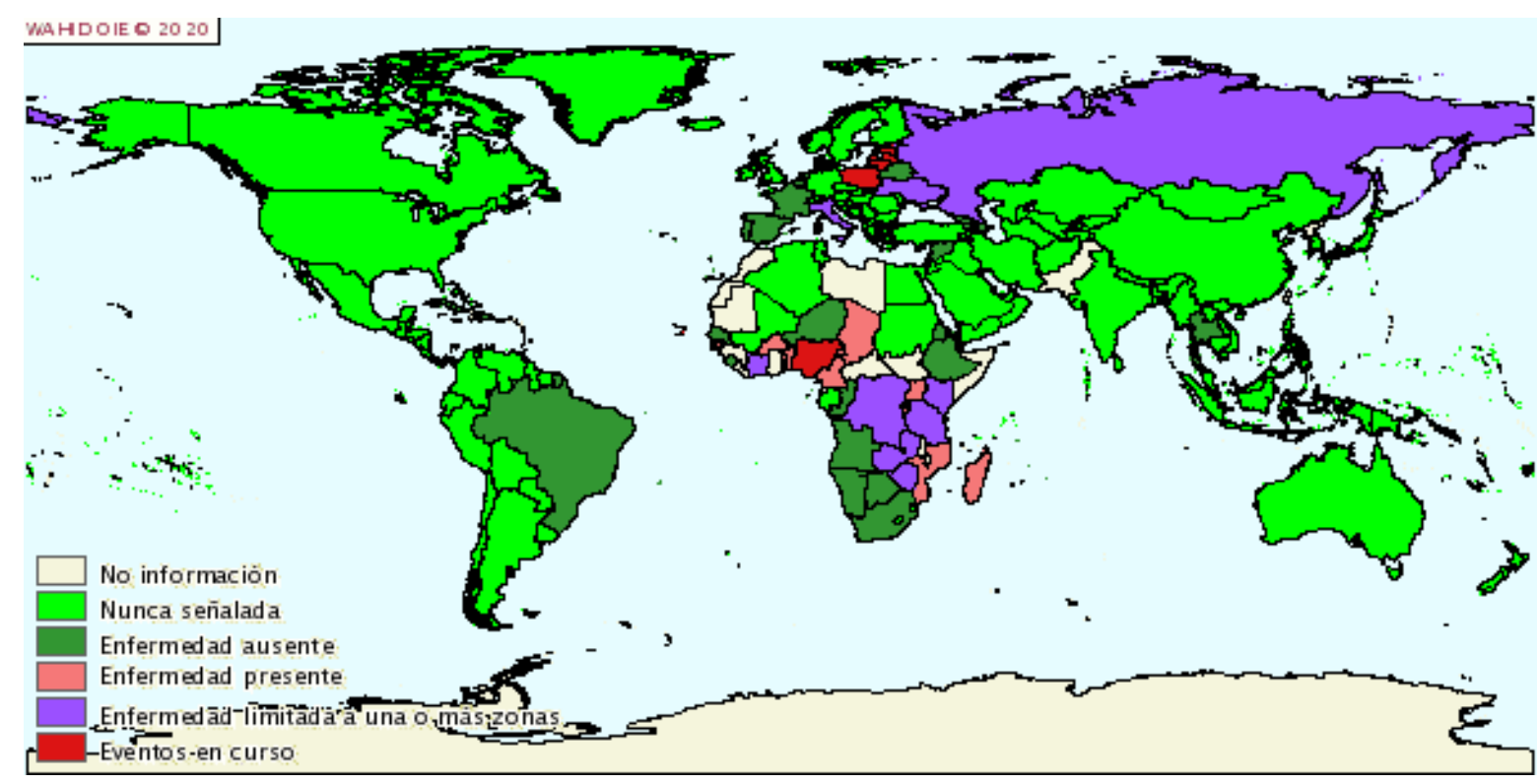


Figura 2. Distribuição geográfica da PSA em 2019 (OIE, 2019b).

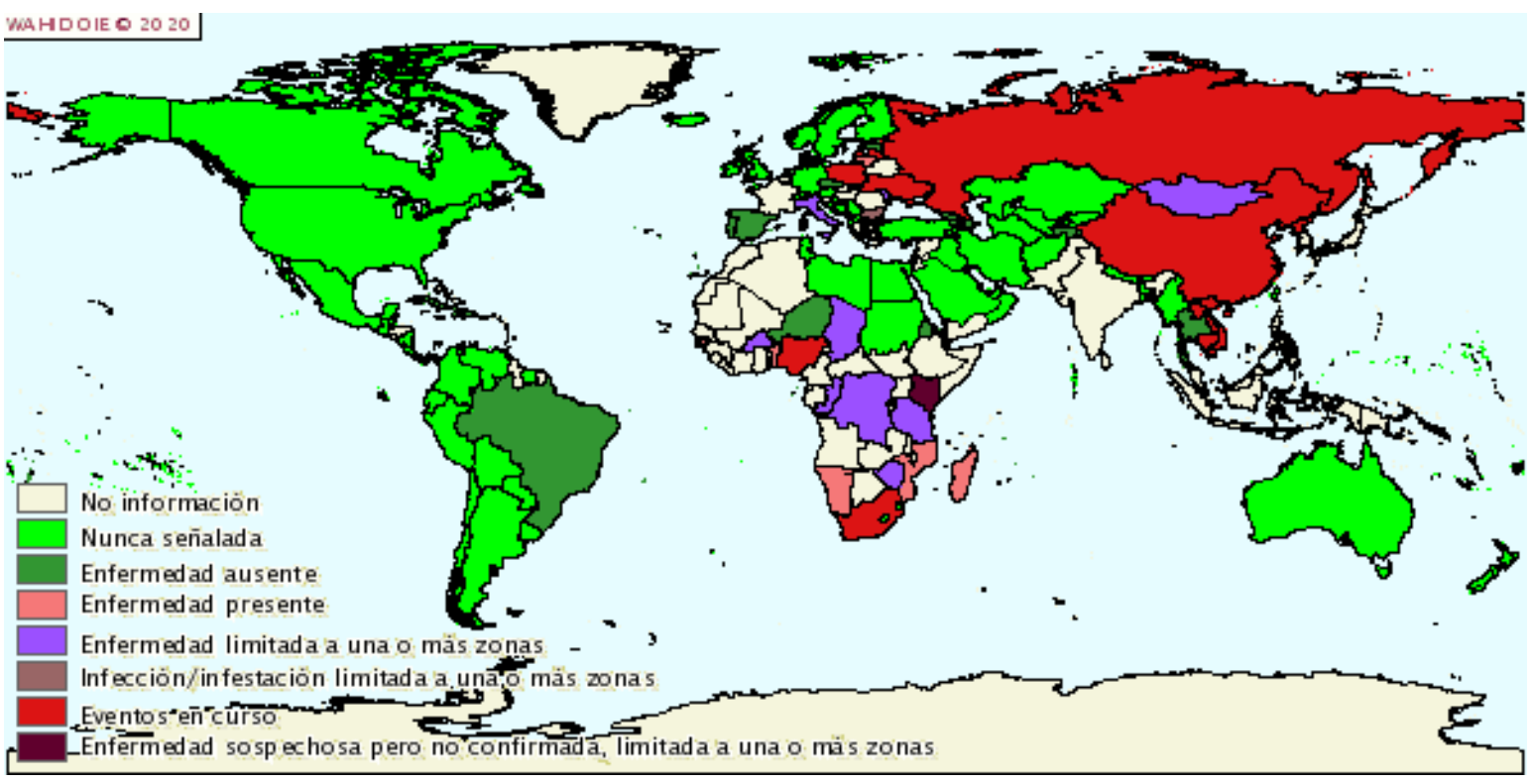

\section{EPIMEDIOLOGIA}

A PSA é considerada uma doença transfronteiriça que afeta a família dos suídeos, incluindo o suíno doméstico, javalis silvestres da Eurásia (Sus scrofa scrofa), javalis (Phacochoerus spp.), porcos do mato (Potamochoerus larvatus e Potamochoerus porcus) e porcos-gigantes da floresta (Hylochoerus spp.) (GAVA et al., 2018a; ROVID, 2019). Os fatores que influenciam na transmissão do vírus dependem do sistema de produção de suíno, da presença ou ausência de vetores (carrapatos) e suínos selvagens e do comportamento humano (OIE, 2018b).

A transmissão do VPSA pode ocorrer por via direta, que é a mais comum entre os suínos domésticos, a qual se dá pelo contato via oro-nasal entre os animais doentes/infectados com os animais saudáveis. A transmissão também ocorre por vetores biológicos (carrapatos moles do gênero Ornithodoros), que transmitem o vírus ao picar o animal, sendo esta a principal forma de transmissão entre javalis, pela ingestão de material contaminado como lixo/lavagem contendo carne infectada (o VPSA pode se manter viável de 3 a 6 meses na carne suína infectada) ou contato com fluídos de suídeos contaminados pelo vírus, sendo estas, vias de transmissão indireta (OURA, 2013; ROVID, 2019; OIE, 2019a).

O trato respiratório superior é a principal via de infecção. Ao infectar o hospedeiro o vírus se replica nas amígdalas e linfonodos que drenam a cabeça e o pescoço e leva a uma infecção generalizada. O vírus foi encontrado em todas as secreções e excreções dos suínos 
domésticos doentes, com concentrações particularmente elevadas no fluido oro-nasal, fazendo do trato respiratório superior a principal via de excreção do VPSA (OURA, 2013; ROVID, 2019).

Os carrapatos moles Ormithodoros sp. e os javalis ou porcos do mato podem ser reservatórios naturais do VPSA, através do ciclo entre o carrapato e esses suídeos, que geralmente são assintomáticos, e os carrapatos podem apresentar transmissão transestadial, transovarial e sexual. Esses fatores podem complicar ou impedir a erradicação desta enfermidade (GAVA et al., 2019; ROVID, 2019). Apesar dos reservatórios naturais, Miranda et al. (2020) cita que 70 \% das causas de difusão da doença são derivadas da ação humana, como prática da caça (podendo disseminar o vírus do ambiente selvagem para o doméstico), alimentação de suínos com restos de alimentos que contenham carne suína ou derivados não cozidos e através fômites, veículos, ração e equipamentos contaminados (CARON, 2019; ROVID, 2019). Esse dado ressalta a importância da conscientização e da prática das medidas de biosseguridade nas granjas de produção de suínos e principalmente nas criações de subsistência que podem ser a porta de entrada desta enfermidade.

Apesar de não ser uma zoonose, essa doença é de grande relevância, pois possui uma rápida disseminação e apresenta altas taxas de mortalidade, também o fato de não haver vacinas preventivas fazem com que a PSA provoque grande perdas econômicas e é uma questão central para a segurança alimentar mundial (OURA, 2013; GAVA et al., 2019; ROVID, 2019).

\section{DIAGNÓSTICO DIFERENCIAL}

A PSA e a peste suína clássica (PSC) são enfermidades com características semelhantes (aspectos clínico-patológicos, espécie acometida, formas de transmissão e características de morbidade e mortalidade parecidos), ambas são uma doença viral grave que afetam suínos e resultam em grandes perdas econômicas, porém são enfermidades distintas, sendo sua principal diferenciação através do diagnostico laboratorial. Enquanto a PSC é causada por um vírus do gênero Pestvirus de genoma RNA da família Flaviridae (BRASIL, 2019a) a PSA é causada por um vírus DNA do gênero Asfivirus da família Asfaviridae (GAVA et al., 2018a). Além da PSC deve-se incluir para diagnóstico diferencial outras enfermidades, como a síndrome reprodutiva e respiratória do suíno (PRRS), erisipela, salmonelose, doença 
de Aujeszky (ou pseudoraiva), pasteurelose ou outras condições septicêmicas (OIE, 2019a; GAVA et al., 2018a).

O diagnóstico laboratorial deve ser realizado em laboratórios oficiais e as amostras de escolha são linfonodos gastro-hepáticos, rim, baço, pulmão, sangue e soro. As técnicas de diagnóstico mais utilizadas para a detecção e identificação do vírus são a imunofluorescência direta, teste de hemadsorção e PCR. Para programas de controle e erradicação da PSA é indicado o teste de ELISA para detecção de anticorpos (GAVA et al., 2019; ROVID, 2019).

\section{BIOSSEGURIDADE: A MELHOR ESTRATÉGIA}

Pelo fato de a PSA ser uma doença que não tem cura e não possui vacinas desenvolvidas, a adoção de práticas apropriadas de importação e medidas de biosseguridade tornam-se as melhores estratégias para evitar a entrada da doença nos países livres desta enfermidade, como também o seu controle em países endêmicos. As medidas de biosseguridade podem variar de acordo com o país, região, sistema de produção adotados e legislações vigentes do local (OURA, 2013).

De acordo com a EMBRAPA (2016), a biosseguridade pode ser definida como medidas que evitam a entrada e propagação de doenças no rebanho, como a adoção de barreiras físicas, medidas de higiene, medidas restritivas e controle de visitas, adoção de vazio sanitário, programas de vacinações, isolamento e tratamento de animais que adoecem, entre outras medidas, todas essas práticas devem estar associadas com as práticas de manejo dos animais ligadas ao bem-estar animal e aliado com a capacitação dos operários com programas de Boas Práticas de Produção e sistema de gestão de qualidade.

Em países livres da PSA, como o Brasil, a OIE (2018b) instrui medidas preventivas visando garantir que porcos vivos não sejam infectados nem os produtos de suínos sejam introduzidos em áreas livres da doença. Como medidas estão: o descarte correto de alimentos de aeronaves, navios ou veículos provenientes de países afetados e policiar as importações ilegais de suínos e produtos de suínos dos países afetados.

Em países que ocorrem os surtos deve ser avaliada a situação epidemiológica da região para a adoção de medidas específicas, mas as medidas clássicas são: a detecção precoce e o sacrifício sanitário dos animais (com o descarte adequado das carcaças e seus resíduos); limpeza e desinfecção completa das instalações; controle de zoneamento e movimentação; vigilância e investigação epidemiológica e medidas estritas de biossegurança nas fazendas. Se 
no país onde houver surto com o envolvimento do vetor, o carrapato, devem ser adotadas medidas para controle desse vetor também (OIE, 2018b).

A Associação Brasileira dos Criadores de Suínos (ABCS), em conjunto com uma equipe técnica desenvolveu o material "Prevenção e Controle Peste Suína Africana e Peste Suína Clássica" (LUDTKE et al., 2019) para melhorar a adoção de medidas de biosseguridade nas granjas produtoras de suínos e prevenir a introdução do vírus no país.

Neste material técnico, orienta-se como medidas de biosseguridade a restrição do acesso de pessoas nas unidades de produção, exigindo que estas realizem o vazio sanitário (pelo menos três dias se houve contato com suínos, seja de abatedouro, granjas, feiras etc.); o isolamento e quarentena de suínos importados; o controle de moscas e carrapatos; a tomar banho antes e após a chegada de colaboradores e visitantes, sendo exigida a utilização de roupas e calçados exclusivos da granja; a utilização do livro de visitas como forma de triagem para permitir ou não a entrada de terceiros; o acesso à granja única e exclusivamente pela barreira sanitária (vestiário), com delimitação de área suja (externa) e área limpa (interna); o controle rigoroso no trânsito adotando medidas de lavagens e desinfeção e até vazio sanitário dos transportes quando necessário; e a aquisição de animais reprodutores (matrizes e cachaços) apenas de Granjas de Reprodutores Suídeos Certificados (GRSC) (LUDTKE et al., 2019).

Todas as medidas supracitadas são ações que visam a proteger e/ou controlar a entrada de patógenos nas unidades produtivas. Essas ações são de fácil prática e de baixos custos, se comparado aos prejuízos causados pela introdução de doenças na unidade produtiva, sendo de extrema importância a orientação, conscientização e capacitação dos colaboradores para uma implementação correta e sem falhas dessas medidas.

\section{CONSIDERAÇÕES FINAIS}

A PSA é uma enfermidade que causa grandes prejuízos socioeconômicos, sendo seus efeitos sentidos não apenas na região afetada, mas sim mundialmente. Devido à ausência de vacinas e suas altas taxas de morbidade e mortalidade, as medidas de biosseguridade são a melhor estratégia e melhor investimento para manter a unidade produtiva segura da entrada e propagação deste patógenos e outros também indesejados. 
Para sua efetividade recomenda-se investir na orientação, conscientização e comprometimento das pessoas que estão envolvidas direta e indiretamente com o sistema produtivo de suínos.

\section{REFERÊNCIAS}

ASSOCIAÇÃO BRASILEIRA DE PROTEÍNA ANIMAL, ABPA. Relatório anual 2019. 2019. Disponível em: http://abpa-br.org/mercados/\#relatorios. Acesso em: 20 fev. 2020.

BRASIL, Ministério da Agricultura. Decreto n. 81.798 de 15/06/1978. Dispõe sobre a adoção de medidas de emergência para erradicação da Peste Suína Africana. Diário Oficial da União, Sessão 1, 15 jun. 1978. Disponível em: https://www2.camara.leg.br/legin/fed/decret/1970-1979/decreto-81798-15-junho-1978431077-publicacaooriginal-1-pe.html. Acesso em: 19 fev. 2020.

BRASIL. Ministério da Agricultura, Pecuária e Abastecimento. Instrução Normativa n. 50, de 24/09/2013. Diário Oficial da União - seção 1, 25 nov. 2013. Disponível em: http://www.agricultura.gov.br/assuntos/sanidade-animal-e-vegetal/saudeanimal/programas-de-saude-animal/legislacaosuideos/2013IN50de24desetembrode.pdf/view. Acesso em: 20 fev. 2020.

BRASIL. Ministério da Agricultura, Pecuária e Abastecimento. Situação sanitária das doenças de animais terrestres - BRASIL, 2018. Disponível em: https://www.gov.br/agricultura/pt-br/assuntos/sanidade-animal-e-vegetal/saudeanimal/arquivos-sisa/Situacao sanitaria WAHID Brasil 2018 02.pdf. Acesso em: 11 abr. 2020.

BRASIL. Ministério da Agricultura, Pecuária e Abastecimento. Plano Brasil livre de PSC. Secretaria de Defesa Agropecuária - Brasília: MAPA/ACE, 2019a. 57 p.

BRASIL. Ministério da Agricultura, Pecuária e Abastecimento. Exportação. 2019b. Disponível em: https://www.gov.br/agricultura/pt-br/assuntos/sanidade-animal-evegetal/saude-animal/exportacao. Acesso em: 11 abr. 2020.

CARDOSO, L. S. Peste suína africana: desafio do Brasil é manter animais livres da doença letal e sem cura, mas que não afeta humanos. 2019. Disponível em: https://www.embrapa.br/busca-de-noticias/-/noticia/43987217/peste-suina-africanadesafio-do-brasil-e-manter-animais-livres-da-doenca-letal-e-sem-cura-mas-que-nao-afetahumanos. Acesso em: 21 fev. 2020.

CARON, L. Peste Suína Africana ou African Swine Fever. 2019. Disponível em: https://www.alice.cnptia.embrapa.br/bitstream/doc/1115709/1/final9213.pdf. Acesso em: 11 abr. 2020.

EMBRAPA. Biosseguridade. 2016. Disponível em: https://www.embrapa.br/qualidadeda-carne/carne-suina/producao-de-suinos/biosseguridade. Acesso em: 20 fev. 2020. 
GAVA, D.; ZANELLA, J.R.C.; CARON, L. et. al. PSA - Peste Suína Africana - Nota Técnica sobre a peste suína africana (PSA). 2018a. Disponível em: https://www.embrapa.br/suinos-e-aves/psa/nota-tecnica. Acesso em: 19 fev. 2020.

GAVA, D.; ZANELLA, J.R.C.; CARON, L. et. al. PSA - Peste Suína Africana Perguntas mais frequentes. 2018b. Disponível em: https://www.embrapa.br/suinos-eaves/psa/faq. Acesso em: 19 fev. 2020.

GAVA, D.; ZANELLA, J.R.C.; CARON, L. et al. Peste Suína Clássica e Peste Suína Africana: entendendo as doenças e os riscos para o Brasil. Revista do Conselho Federal de Medicina Veterinária-CFMV, n. 82, ano 25, p. 22-26, 2019.

LUDTKE, C.; LOPES, G.; MACHADO, I. P. Prevenção e Controle Peste Suína Africana e Peste Suína Clássica. 2019. Disponível em: http://www.abcs.org.br/images/materiais-tecnicos/pestes-prevencao-controle.pdf. Acesso em: 19 fev. 2020.

LYRA, T. M. P. La erradicación de la peste porcina africana en el Brasil, 1978-1984. Scientific and Technical Review of the Office International des Epizooties, v.25, n.1, p.93-103, 2006.

LYRA, T. M. P.; FREITAS, T. R. Epizootiology, laboratory and virulence analyses during the emergency phase of the African swine fever eradication program in Brazil in 1978: a historic account. Semina: Ciências Agrárias, Londrina, v. 36, n. 4, p. 2577-2592, jul/ago. 2015.

MIRANDA, S.H.G.; CORRER, N.G.; DAMASCENO, R.; MENEZES, T.C. Peste Suína Africana: os desafios e as oportunidades que a globalização adiciona à gestão sanitária. Centro de Estudos Avançados em Economia Aplicada, v. 1, n. 1, janeiro 2020.

OIE. Base de datos del Sistema mundial de información zoosanitária (WAHIS Interface). 2015. Disponível em:

https://www.oie.int/wahis 2/public/wahid.php/Diseaseinformation/Diseasedistribution map? disease type hidden $=\&$ disease $i d$ hidden $=\&$ selected disease name hidden $=\&$ disea se type $=0 \&$ disease $i d$ terrestrial $=12 \&$ species $\mathrm{t}=0 \&$ disease $\mathrm{id}$ aquatic $=$ -

999\&species a $=0 \&$ sta method $=$ semesterly\&selected start year $=2015 \&$ selected report $\mathrm{p}$ eriod $=2 \&$ selected start month=1\&date submit $=$ OK. Acesso em: 12 abr. 2020.

OIE. Global situation of ASF. 2018a. Disponível em: https://www.oie.int/fileadmin/Home/eng/Animal Health in the World/docs/pdf/Dis ease cards/Report 1. Global situation of ASF Updated 191018.pdf. Acesso em: 12 abr. 2020.

OIE. African Swine Fever. 2018b. Disponível em: https://www.oie.int/en/animal-healthin-the-world/animal-diseases/african-swine-fever. Acesso em: 19 fev. 2020.

OIE. African Swine Fever. 2019a. Disponível em: https://www.oie.int/fileadmin/Home/eng/Animal Health in the World/docs/pdf/Dis ease cards/AFRICAN SWINE FEVER.pdf. Acesso em 19 fev. 2020.

OIE. Base de datos del Sistema mundial de información zoosanitária (WAHIS Interface). 2019b. Disponível em: 
https://www.oie.int/wahis 2/public/wahid.php/Diseaseinformation/Diseasedistribution map/index/newlang/es?disease type hidden $=\&$ disease id hidden $=\&$ selected disease na me hidden $=\&$ disease type $=0 \&$ disease id terrestrial $=12 \&$ species $\mathrm{t}=0 \&$ disease id aquatic 三-

999\&species a $=0$ \&sta method $=$ semesterly\&selected start year $=2019 \&$ selected report p eriod $=1 \&$ selected start month=1\&date submit $=$ OK. Acesso em: 12 abr. 2020.

OIE. African Swine Fever - Latest Reports on African Swine Fever. 2020a. Disponível em: $\quad$ https://www.oie.int/en/animal-health-in-the-world/information-on-aquatic-andterrestrial-animal-diseases/african-swine-fever/reports-on-asf/. Acesso em: 10 abr. 2020.

OIE. Listed diseases, infections and infestations in force in 2020. 2020b. Disponível em: https://www.oie.int/animal-health-in-the-world/oie-listed-diseases-2020/. Acesso em: 19 fev. 2020.

OURA, C. Overview of African Swine Fever. 2013. Disponível em:

https://www.merckvetmanual.com/generalized-conditions/african-swine-fever/overviewof-african-swine-fever?query $=$ swine $\% 20$ fever. Acesso em: 11 abr. 2020

ROVID, A. Peste Suína Africana. Traduzido e adaptado a situação do Brasil por Mendes, Ricardo, 2019.

Disponível em: http://www.cfsph.iastate.edu/Factsheets/pt/african-swine-fever-PT.pdf. Acesso em: 11 abr. 2020. 

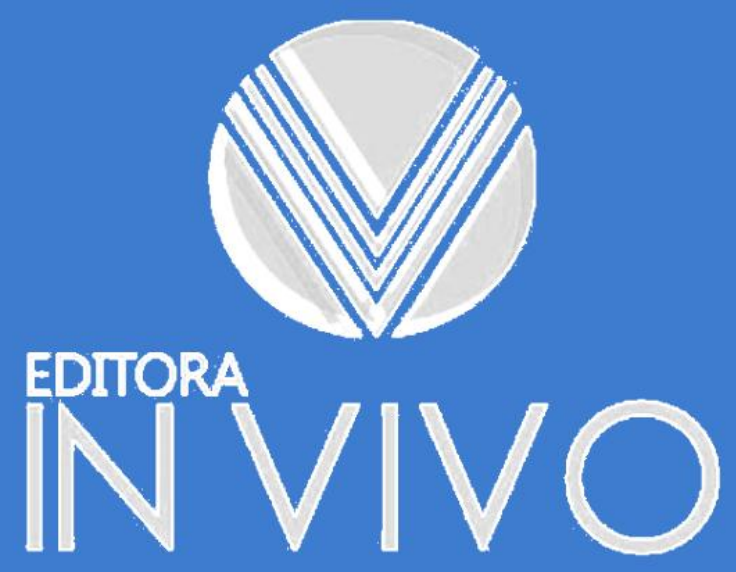

\section{www.editorainvivo.com}

Avance na ciência! Venha ser In Vivo! 